\title{
Arbeidsmarktinformatie naar bedrijfssector, beroep en opleiding voor de provincie Noord-Holland
}

Citation for published version (APA):

Wieling, M., \& de Grip, A. (1994). Arbeidsmarktinformatie naar bedrijfssector, beroep en opleiding voor de provincie Noord-Holland. Researchcentrum voor Onderwijs en Arbeidsmarkt, Faculteit der Economische Wetenschappen. ROA Reports No. 1 https://doi.org/10.26481/umarep.1994001

Document status and date:

Published: 01/01/1994

DOI:

10.26481/umarep.1994001

Document Version:

Publisher's PDF, also known as Version of record

\section{Please check the document version of this publication:}

- A submitted manuscript is the version of the article upon submission and before peer-review. There can be important differences between the submitted version and the official published version of record.

People interested in the research are advised to contact the author for the final version of the publication, or visit the DOI to the publisher's website.

- The final author version and the galley proof are versions of the publication after peer review.

- The final published version features the final layout of the paper including the volume, issue and page numbers.

Link to publication

\footnotetext{
General rights rights.

- You may freely distribute the URL identifying the publication in the public portal. please follow below link for the End User Agreement:

www.umlib.nl/taverne-license

Take down policy

If you believe that this document breaches copyright please contact us at:

repository@maastrichtuniversity.nl

providing details and we will investigate your claim.
}

Copyright and moral rights for the publications made accessible in the public portal are retained by the authors and/or other copyright owners and it is a condition of accessing publications that users recognise and abide by the legal requirements associated with these

- Users may download and print one copy of any publication from the public portal for the purpose of private study or research.

- You may not further distribute the material or use it for any profit-making activity or commercial gain

If the publication is distributed under the terms of Article $25 \mathrm{fa}$ of the Dutch Copyright Act, indicated by the "Taverne" license above, 


\section{ARBEIDSMARKTINFORMATIE NAAR BEDRIJFSSECTOR, BEROEP EN OPLEIDING VOOR DE PROVINCIE NOORD-HOLLAND}

ROA-R-1994/1

M.H. Wieling

A. de Grip

RESEARCHCENTRUM VOOR ONDERWIJS EN ARBEIDSMARKT

Faculteit der Economische Wetenschappen

Rijksuniversiteit Limburg

Maastricht, januari 1994 
CIP-GEGEVENS KONINKLIJKE BIBLIOTHEEK, DEN HAAG

Weiling, M.H.

Arbeidsmarktinformatie naar bedrijfssector, beroep en opleiding voor de provincie NoordHolland/M.H. Wieling, A. de Grip. - Maastricht: Researchcentrum voor Onderwijs en Arbeidsmarkt, Faculteit der Economische Wetenschappen, Rijksuniversiteit Limburg. - Tab. ([rapport]/Researchcentrum voor Onderwijs en Arbeidsmarkt, ISSN 0922-8098; ROA-R-1994/1) Met lit. opg.

ISBN 90-5321-122-5 geb.

Trefw.: onderwijs en arbeidsmarkt; Noord-Holland. 


\section{INHOUDSOPGAVE}

Bladzijde

1. INLEIDING 1

2. WERKGELEGENHEIDSSTRUCTUUR

2.1. Inleiding 8

2.2. Sectorstructuur 8

2.3. Beroepenstructuur 10

2.4. Opleidingenstructuur 15

$\begin{array}{lr}\text { 2.5. Leeftijdsstructuur } & 19\end{array}$

2.6. Vrouwen op de arbeidsmarkt 23

2.7. Conclusie 27

3. FORENSENSTROMEN 30

3.1. Inleiding 30

3.2. Forensenstromen per bedrijfssector 33

3.3. Forensenstromen per beroepssegment 34

3.4. Forensenstromen per opleidingstype 35

3.5. Conclusie 37

4. BAANVINDERS 39

4.1. Inleiding 39

4.2. Baanvinders per bedrijfstak 40

4.3. Baanvinders per beroepssector 42

4.4. Baanvinders per opleidingscategorie 44

4.5. Conclusie 46

5. VERSCHILLEN IN WERKGELEGENHEIDSSTRUCTUUR 48

5.1. Inleiding 48

5.2. Verschillen in de sectorstructuur 49

5.3. Verschillen in de beroepenstructuur 50

5.4. Verschillen in de opleidingenstructuur 53

6. BESLUIT 56

$\begin{array}{ll}\text { LITERATUUR } & 66\end{array}$

BIJLAGE A: GEHANTEERDE SECTOR-, BEROEPEN- EN OPLEIDINGENINDELINGEN 67

BIJLAGE B: AANVULLENDE TABELLEN 
$\ldots \ldots$ 


\section{INLEIDING}

Voor een adequaat regionaal werkgelegenheids- en arbeidsmarktbeleid is de beschikbaarheid van betrouwbare en voldoende gedetailleerde arbeidsmarktinformatie een noodzakelijke randvoorwaarde (zie ook en De Grip en Heijke, 1993). Maar ook voor andere beleidsterreinen is regionale arbeidsmarktinformatie van belang is. Daarbij kan vooral worden gedacht aan het regionaal economisch beleid, het verkeers- en vervoersbeleid en de ruimtelijke ordening. Vanuit dit oogpunt wil de Provincie Noord-Holland jaarlijks een analyse maken van de ontwikkelingen op de regionale arbeidsmarkt. De afdeling Economische Zaken van de Provincie heeft derhalve aan het Researchcentrum voor Onderwijs en Arbeidsmarkt (ROA) de opdracht gegeven de werkgelegenheidsstructuur in Noord-Holland in kaart te brengen. Daarbij is het enerzijds van belang een beeld te krijgen van de werkgelegenheidssituatie in de provincie Noord-Holland als geheel, om relaties te kunnen leggen tussen de economische ontwikkeling en de arbeidsmarkt. Anderzijds is het ook belangrijk de verschillen tussen de regio's binnen de provincie en de mobiliteitsstromen tussen deze regio's nader te belichten. De vier Regionale Besturen voor de Arbeidsvoorziening (RBA's) binnen de provincie zouden in dat geval ook gebruik kunnen maken van de gepresenteerde arbeidsmarktinformatie. Het gaat daarbij om de RBA-gebieden Het Gooi en Vechtstreek (GV), Noord-Holland Noord (NHN), Amsterdam, Zaanstreek, Waterland (AZW) en Kennemer-, Amstelland en Meerlanden (KAM).

Door jaarlijks de werkgelegenheidsstructuur in beeld te brengen kan inzicht worden verkregen in de ontwikkelingen die er in de provincie Noord-Holland op de arbeidsmarkt plaatsvinden. Om in deze behoefte aan adequate arbeidsmarktinformatie te voorzien, zijn in opdracht van de Provincie Noord-Holland, de gewenste gegevens op basis van de Enquête Beroepsbevolking (EBB) van het Centraal Bureau voor de Statistiek (CBS) aan het ROA aangeleverd. In dit rapport zullen deze gegevens worden gepresenteerd en geanalyseerd. Daarbij zal tevens worden ingegaan op de betrouwbaarheid van de informatie en de conclusies die daaruit moeten worden getrokken met betrekking tot de in de toekomst te hanteren indelingen. Daar dergelijke arbeidsmarktanalyses dit jaar pas voor de eerste keer worden verricht, worden er vooralsnog geen arbeidsmarktontwikkelingen in beeld gebracht. In eerste instantie zal alleen een beeld kunnen worden geschetst van de huidige werkgelegenheidsstructuur, verbijzonderd naar branche, beroep en opleiding en de positie van bepaalde groepen arbeidskrachten op de arbeidsmarkt. Daarbij wordt zowel ingegaan op de werkgelegenheidsstructuur in de provincie Noord-Holland, als op de structuur van de werkgelegenheid in de vier RBA-gebieden binnen de provincie.

Naast de werkgelegenheidsstructuur van de werkzame personen, worden in dit rapport ook de forensenstromen in de provincie Noord-Holland in beeld gebracht. Daarbij zal een onderscheid worden gemaakt tussen de inkomende en uitgaande pendel. Een ander aandachtspunt is de arbeidsmarktpositie van de baanvinders. Dit zijn degenen die op de enquêtedatum een werkkring 
hadden waarin ze korter dan één jaar werkzaam waren (zie Bierings en Windmeijer, 1992) ${ }^{1}$.

\section{De Enquête Beroepsbevolking}

De EBB is een doorlopende enquête die sinds 1987 door het CBS wordt gehouden. De totale jaarlijkse steekproef heeft betrekking op ongeveer 120.000-130.000 adressen. Het aantal geënquêteerde personen van $15-64$ jaar is jaarlijks circa 100.000 tot 110.000 . Dit komt overeen met een steekproeffractie van $1 \%$. De steekproefuitkomsten zijn door het CBS opgehoogd tot de 'werkelijke' aantallen. Bij deze ophoging wordt gestratificeerd naar geslacht leeftijd, burgelijke staat, nationaliteit en regio (zie CBS, 1990, 1991 en 1992).

In de EBB is een groot aantal arbeidsmarktgegevens opgenomen. Dit betreft onder meer:

- demografische kenmerken (geslacht, leeftijd, nationaliteit);

- belangrijkste activiteit (werkzaam, scholier/student, enz.);

- gemeente waar men woont en werkt;

- gevolgde opleiding;

- bedrijfsklasse waarin men werkt;

- beroep dat men uitoefent;

- arbeidsduur;

- het al dan niet op zoek zijn naar werk.

De in dit rapport gepresenteerde gegevens zijn gebaseerd op de nieuwe definities van de beroepsbevolking. Dit betekent dat alleen degenen met een wekelijkse arbeidstijd van tenminste 12 uur tot de werkzame personen worden gerekend (zie ook CBS, 1993a).

De beschikbare informatie over de werkenden zal voor zover mogelijk worden verbijzonderd naar leeftijd, geslacht, branche, beroep, opleiding en werkregio. Alle gegevens in dit rapport hebben betrekking op de provincie Noord-Holland en de vier RBA-gebieden als werkgebied. Daarbij moet het volgende worden opgemerkt. Het werkgebied van een respondent is bepaald aan de hand van de gemeente waar men doorgaans de werkzaamheden verricht. Voor een aanzienlijk aantal geënquêteerde personen is dit echter onbekend. Alle gegevens in dit rapport betreffen uitsluitend personen van wie bekend is in welke gemeente van Noord-Holland men werkzaam is. Dit betekent dat het werkelijke aantal personen dat betaald werk verricht wordt onderschat. Deze onderschatting is bovendien niet aselectief, daar het onbekend zijn van de werkgemeente samenhangt met enkele specifieke branches en beroepen.

Bijna alle gegevens in dit rapport representeren het gemiddelde van de periode $1989-1991^{2}$.

1. Anders dan in het artikel van Bierings en Windmeijer (1992), heeft het begrip baanvinders niet alleen betrekking op degenen die op de enquêtedatum een werkkring in loondienst hadden, waarin ze korter dan één jaar werkzaam zijn, maar ook op zelfstandigen en meewerkende gezinsleden.

2. Op het gewenste aggregatieniveau waren ten tijde van de verzameling van de data nog geen regionale gegevens voor het jaar 1992 beschikbaar. 
Alleen als het gaat om opleidingsinformatie, betreffen de cijfers de tweejaarsperiode 19901991.

\section{Betrouwbaarheidsmarges}

Het voordeel van het gebruik van meerjaarlijkse gemiddelden is dat de informatie 'harder' is dan wanneer wordt uitgegaan van de cijfers voor éen bepaald jaar. Bovendien kan op deze wijze meer informatie worden verkregen, aangezien voor drie- en tweejaarsgemiddelden de cijfers reeds gepubliceerd mogen worden bij een minimaal aantal personen van respectievelijk 2.000 en 3.000. Daarentegen geldt bij jaarcijfers een ondergrens van 5.000 personen. Daarbij kan in het geval van driejaarsgemiddelden een afronding op 500-tallen plaatsvinden, terwij in de beide andere gevallen op 1.000-tallen moet worden afgerond. Dit is overeenkomstig de werkwijze zoals het CBS die in haar eigen publikaties hanteert. Deze publikatierestricties vloeien met name voort uit de eis dat individuele respondenten niet herkenbaar mogen zijn in de gepresenteerde gegevens.

Tabel 1.1. Betrouwbaarheidsmarges van de opgehoogde EBB-aantallen 1989, 1990 en 1991 (95\%)

\begin{tabular}{|c|c|c|c|c|c|c|}
\hline \multirow{2}{*}{$\begin{array}{l}\text { Opgehoogde } \\
\text { aantallen }\end{array}$} & \multicolumn{2}{|c|}{ marges 1989} & \multicolumn{2}{|c|}{ marges 1990} & \multicolumn{2}{|c|}{ marges $1991^{*}$} \\
\hline & absoluut & $\%$ & absoluut & $\%$ & absoluut & $\%$ \\
\hline 5.000 & 1.300 & 25,8 & 1.400 & 27,9 & 1.500 & 30,0 \\
\hline 10.000 & 1.800 & 18,2 & 2.000 & 19,8 & 2.100 & 21,2 \\
\hline 15.000 & 2.200 & 14,9 & 2.400 & 16,1 & 2.600 & 17,3 \\
\hline 20.000 & 2.600 & 12,9 & 2.800 & 14,0 & 3.000 & 15,0 \\
\hline 30.000 & 3.200 & 10,5 & 3.400 & 11,4 & 3.700 & 12,2 \\
\hline 50.000 & 4.100 & 8,1 & 4.400 & 8,8 & 4.700 & 9,5 \\
\hline 75.000 & 5.000 & 6,6 & 5.400 & 7,2 & 5.800 & 7,7 \\
\hline 100.000 & 5.700 & 5,7 & 6.200 & 6,2 & 6.700 & 6,7 \\
\hline 200.000 & 8.100 & 4,0 & 8.700 & 4,4 & 9.400 & 4,7 \\
\hline 300.000 & 9.800 & 3,3 & 10.700 & 3,6 & 11.500 & 3,8 \\
\hline 500.000 & 12.600 & 2,5 & 13.600 & 2,7 & 14.600 & 2,9 \\
\hline 750.000 & 15.200 & 2,0 & 16.500 & 2,2 & 17.700 & 2,4 \\
\hline 1.000 .000 & 17.300 & 1,7 & 18.800 & 1,9 & 20.200 & 2,0 \\
\hline 2.000 .000 & 23.100 & 1,2 & 25.000 & 1,3 & 26.900 & 1,3 \\
\hline 3.000 .000 & 26.400 & 0,9 & 28.700 & 1,0 & 30.900 & 1,0 \\
\hline 5.000 .000 & 28.700 & 0,6 & 31.300 & 0,6 & 33.800 & 0,7 \\
\hline 7.500 .000 & 24.600 & 0,3 & 27.300 & 0,4 & 29.700 & 0,4 \\
\hline
\end{tabular}

Bron: CBS (1990, 1991 en 1992)

In de EBB-publikaties van het CBS worden de 95\%-betrouwbaarheidsmarges van de uitkomsten gepresenteerd. Tabel 1.1 geeft de absolute en relatieve marges die bij de (opgehoogde) aantallen in acht moeten worden genomen voor respectievelijk de jaren 1989, 1990 en $1991^{3}$. Vooral bij kleine aantallen zijn de marges relatief groot. Zo blijkt uit de tabel dat bij een gepresenteerd aantal van 5.000 in 1991 slechts kan worden gezegd dat dit aantal met 95\%-

3. Overigens kunnen er naast steekproeffouten ook afwijkingen optreden, die zijn veroorzaakt door meetfouten, fouten in het steekproefkader, fouten als gevolg van selectiviteit in de non-respons en verwerkingsfouten (zie CBS, 1990, 1991 en 1992). 
betrouwbaarheid in het interval 3.500 tot 6.500 ligt. De relatieve marges worden kleiner naarmate het gepresenteerde aantal groter is. Bij een gepresenteerd aantal van 100.000 kan er met 95\%-betrouwbaarheid van uit worden gegaan dat het werkelijke aantal tussen 93.300 en 106.700 ligt, een marge naar boven en naar beneden van $6,7 \%$.

Tabel 1.2 laat zien welk effect het presenteren van meerjaarlijkse gemiddelden heeft op de betrouwbaarheidsmarges van de EBB. De tabel geeft een overzicht van de absolute en relatieve marges bij een 95\%-betrouwbaarheid voor de perioden 1989-1991 en 1990-1991. In vergelijking tot de jaarlijkse betrouwbaarheidsmarges in tabel 1.1 valt op dat de marges bij de twee- en driejaarsgemiddelden beduidend kleiner zijn. Uit de tabel blijkt dat met name bij de driejaarsgemiddelden de relatieve marges aanzienlijk kleiner zijn. Dit is vooral van belang voor de informatie die betrekking heeft op de kleinere aantallen werkenden die bij regionale gegevens nogal eens voor zullen komen.

Tabel 1.2. Betrouwbaarheidsmarges van de opgehoogde EBB-aantallen 1989-1991 en 1990-1991 (95\%)

\begin{tabular}{rrrrr}
\hline $\begin{array}{c}\text { Opgehoogde } \\
\text { aantallen }\end{array}$ & marges $1989-1991$ & \multicolumn{2}{c}{ marges $1990-1991$} \\
absoluut & $\%$ & absoluut & $\%$ \\
\hline 2.000 & 500 & 26,1 & 700 & 33,6 \\
3.000 & 600 & 21,2 & 800 & 27,1 \\
4.000 & 700 & 17,8 & 900 & 22,1 \\
5.000 & 800 & 16,2 & 1.000 & 20,5 \\
10.000 & 1.100 & 11,4 & 1.500 & 14,5 \\
15.000 & 1.400 & 9,3 & 1.800 & 11,8 \\
20.000 & 1.600 & 8,1 & 2.100 & 10,3 \\
30.000 & 2.000 & 6,6 & 2.500 & 8,4 \\
50.000 & 2.500 & 5,1 & 3.200 & 6,4 \\
75.000 & 3.100 & 4,2 & 4.000 & 5,3 \\
100.000 & 3.600 & 3,6 & 4.600 & 4,6 \\
200.000 & 5.100 & 2,5 & 6.400 & 3,2 \\
300.000 & 6.200 & 2,1 & 7.900 & 2,6 \\
500.000 & 7.900 & 1,6 & 10.000 & 2,0 \\
750.000 & 9.500 & 1,3 & 12.100 & 1,6 \\
1.000 .000 & 10.900 & 1,1 & 13.800 & 1,4 \\
2.000 .000 & 14.500 & 0,7 & 18.400 & 0,9 \\
3.000 .000 & 16.600 & 0,6 & 21.100 & 0,7 \\
5.000 .000 & 18.100 & 0,4 & 23.000 & 0,5 \\
7.500 .000 & 15.700 & 0,2 & 20.200 & 0,3 \\
\hline
\end{tabular}

Bron: CBS

De tabel laat zien dat bij een gemiddeld aantal werkenden van 5.000 in de periode 1989-1991 kan worden gezegd dat dit aantal met $95 \%$-betrouwbaarheid in het interval 4.200 tot 5.800 ligt. Voor de periode 1990-1991 is het interval 4.000 tot 6.000. Een gepresenteerd aantal werkenden van 100.000 voor de periode 1989-1991 ligt naar alle waarschijnlijkheid tussen de 96.400 en 103.600. Voor gemiddelden over de periode 1990-1991 zijn de marges groter, hiervoor liggen de aantallen naar alle waarschijnlijkheid tussen 95.400 en 104.600 .

Betrouwbaarheidsmarges van $95 \%$ impliceren een aan zekerheid grenzende waarschijnlijkheid. Om een indicatie te krijgen van de implicaties van minder strenge betrouwbaarheidseisen, wordt in tabel 1.3 voor de jaren 1989, 1990 en 1991 een overzicht gegeven van de absolute en 
relatieve marges die bij de gepresenteerde aantallen werkenden in acht moeten worden genomen, wanneer wordt uitgegaan van $70 \%$-betrouwbaarheidsmarges ${ }^{4}$. De tabel laat zien dat de marges in dat geval aanzienlijk kleiner zijn dan bij betrouwbaarheidsmarges van $95 \%$. Zo blijkt uit de tabel dat bij een gepresenteerd aantal werkenden van 5.000 in 1991 kan worden gezegd dat dit aantal met $70 \%$-betrouwbaarheid in het interval 4.200 tot 5.800 ligt (bij $95 \%$ betrouwbaarheid bedroeg de marge 3.500 tot 6.500 ). Bij een gepresenteerd aantal werkenden van 100.000 in 1991 kan er met $70 \%$-betrouwbaarheid van uit worden gegaan dat het werkelijke aantal tussen 96.500 en 103.500 ligt, terwijl dit aantal bij 95\%-betrouwbaarheid tussen de 93.300 en 106.700 ligt.

Tabel 1.3. Betrouwbaarheidsmarges van de opgehoogde EBB-aantallen 1989, 1990 en 1991 (70\%)

\begin{tabular}{|c|c|c|c|c|c|c|}
\hline \multirow{2}{*}{$\begin{array}{l}\text { Opgehoogde } \\
\text { aantallen }\end{array}$} & \multicolumn{2}{|c|}{ marges 1989} & \multicolumn{2}{|c|}{ marges 1990} & \multicolumn{2}{|c|}{ marges $1991^{*}$} \\
\hline & absoluut & $\%$ & absoluut & $\%$ & absoluut & $\%$ \\
\hline 2.000 & 400 & 21,6 & 500 & 23,3 & 500 & 25,1 \\
\hline 3.000 & 500 & 17,6 & 600 & 19,0 & 600 & 20,5 \\
\hline 4.000 & 600 & 15,3 & 700 & 16,4 & 700 & 17,7 \\
\hline 5.000 & 700 & 13,6 & 700 & 14,7 & 800 & 15,9 \\
\hline 10.000 & 1.000 & 9,6 & 1.000 & 10,4 & 1.100 & 11,2 \\
\hline 15.000 & 1.200 & 7,9 & 1.300 & 8,5 & 1.400 & 9,2 \\
\hline 20.000 & 1.400 & 6,8 & 1.500 & 7,3 & 1.600 & 7,9 \\
\hline 30.000 & 1.700 & 5,6 & 1.800 & 6,0 & 1.900 & 6,5 \\
\hline 50.000 & 2.200 & 4,3 & 2.300 & 4,6 & 2.500 & 5,0 \\
\hline 75.000 & 2.600 & 3,5 & 2.800 & 3,8 & 3.100 & 4,1 \\
\hline 100.000 & 3.000 & 3,0 & 3.300 & 3,3 & 3.500 & 3,5 \\
\hline 200.000 & 4.300 & 2,1 & 4.600 & 2,3 & 5.000 & 2,5 \\
\hline 300.000 & 5.200 & 1,7 & 5.600 & 1,9 & 6.100 & 2,0 \\
\hline 500.000 & 6.700 & 1,3 & 7.200 & 1,4 & 7.700 & 1,5 \\
\hline 750.000 & 8.000 & 1,1 & 8.700 & 1,2 & 9.400 & 1,2 \\
\hline 1.000 .000 & 9.200 & 0,9 & 9.900 & 1,0 & 10.700 & 1,1 \\
\hline
\end{tabular}

Bron: ROA

Tabel 1.4 geeft een overzicht van de absolute en relatieve marges die bij $70 \%$-betrouwbaarheidsmarges in acht moeten worden genomen voor de perioden 1989-1991 en 1990-1991. De tabel dat laat zien bij een gemiddeld aantal werkenden in de periode 1989-1991 van 5.000 kan worden gezegd dat dit aantal met $70 \%$-betrouwbaarheid in het interval 4.600 tot 5.400 ligt, terwijl er bij de $95 \%$-betrouwbaarheidsmarges sprake is van het interval 4.200-5.800. Voor de periode $1990-1991$ is het interval 4.500 tot 5.500 , ten opzichte van $4.000-6.000$ bij $95 \%$ betrouwbaarheidsmarges. Een gepresenteerd aantal werkenden van 100.000 voor de periode 1989-1991 ligt bij 70\%-betrouwbaarheid tussen de 98.000 en 102.000, terwijl het interval bij $95 \%$-betrouwbaarheid $96.400-103.600$ is. Voor gemiddelden over de periode $1990-1991$ is het interval bij $70 \%$-betrouwbaarheid 97.600 tot 102.400 tegenover een interval van 95.400 tot 104.600 bij $95 \%$-betrouwbaarheid.

4. Hierbij moet worden opgemerkt dat deze gegevens benaderingen betreffen, aangezien de exacte steekproefmarge en de omvang van de bevolkingsgroep waarop de enquête betrekking heeft niet bekend zijn. 
Tabel 1.4. Betrouwbaarheidsmarges van de opgehoogde EBB-aantallen 1989-1991 en 1990-1991 (70\%)

\begin{tabular}{rrrrr}
\hline $\begin{array}{c}\text { Opgehoogde } \\
\text { aantallen }\end{array}$ & $\begin{array}{c}\text { marges } 1989-1991 \\
\text { absoluut }\end{array}$ & $\%$ & \multicolumn{2}{c}{ marges $1990-1991$} \\
absoluut & $\%$ \\
\hline 2.000 & 300 & 14,4 & 400 & 17,7 \\
3.000 & 300 & 11,5 & 400 & 14,1 \\
4.000 & 400 & 10,1 & 500 & 12,4 \\
5.000 & 400 & 8,9 & 500 & 10,6 \\
10.000 & 600 & 6,2 & 700 & 7,4 \\
15.000 & 800 & 5,3 & 1.000 & 6,4 \\
20.000 & 900 & 4,5 & 1.100 & 5,5 \\
30.000 & 1.100 & 3,6 & 1.300 & 4,4 \\
50.000 & 1.400 & 2,8 & 1.700 & 3,4 \\
75.000 & 1.700 & 2,3 & 2.100 & 2,8 \\
100.000 & 2.000 & 2,0 & 2.400 & 2,4 \\
200.000 & 2.800 & 1,4 & 3.400 & 1,7 \\
300.000 & 3.400 & 1,1 & 4.100 & 1,4 \\
500.000 & 4.400 & 0,9 & 5.300 & 1,1 \\
750.000 & 5.300 & 0,7 & 6.400 & 0,9 \\
1.000 .000 & 6.000 & 0,6 & 7.300 & 0,7 \\
\hline
\end{tabular}

Bron: ROA

In de volgende hoofdstukken zal bij de opgenomen tabellen steeds een indicatie worden gegeven van de betrouwbaarheid van de gepresenteerde gegevens. In een aantal tabellen worden de sectoren, beroepen of opleidingen gerangschikt naar de grootte van de betrouwbaarheidsmarges. Daarbij wordt telkens een driedeling aangebracht. Als eerste worden de sectoren, beroepen of opleidingen weergegeven waarvoor de marges relatief klein zijn, dat zijn de categorieën met tenminste 10.000 werkzame personen. Vervolgens worden de sectoren, beroepen of opleidingen met tenminste 5.000 maar minder dan 10.000 werkenden getypeerd als arbeidsmarktinformatie met redelijke marges. De sectoren, beroepen of opleidingen met minder dan 5.000 werkenden hebben te maken met grote marges. In de overige tabellen wordt telkens met "*' aangegeven dat het gaat om cellen met minder dan 5.000 werkenden. Indien in deze tabellen percentages worden gepresenteerd, wordt de betrouwbaarheid van de gegevens bepaald op basis van het aantal in de teller. De cellen met minder dan 5.000 werkenden zullen overigens niet in de bespreking van de tabel worden betrokken.

\section{Opzet van het rapport}

De verdere opbouw van dit rapport is als volgt. Eerst wordt in hoofdstuk 2 een beeld geschetst van de huidige structuur van de werkgelegenheid in de provincie Noord-Holland. Daarbij zal een onderscheid worden gemaakt tussen de bedrijfssectorenstructuur, de beroepenstructuur en de opleidingenstructuur. Voor zover mogelijk wordt de situatie in de provincie Noord-Holland daarbij vergeleken met de rest van Nederland. Tevens zal worden aangegeven in hoeverre er op de desbetreffende punten sprake is van duidelijke verschillen tussen de vier RBA-gebieden binnen de provincie. Bovendien wordt in dit hoofdstuk de leeftijdsstructuur van de werkzame personen en de arbeidsmarktpositie van vrouwen nader in beeld gebracht. Hoofdstuk 3 gaat vervolgens in op de forensenstromen in de provincie. In hoofdstuk 4 wordt de arbeidsmarktpositie van degenen die recent een nieuwe werkkring hebben gevonden nader belicht. Daarbij moet worden opgemerkt dat de opzet van de hoofdstukken 2 tot en met 4 enigszins verschillend is. Dit hangt 
$-7-$

samen met de verschillen in de beschikbare data. Zo zal in de hoofdstukken 3 en 4 de informatie die niet kan worden verbijzonderd naar branche, beroep en opleiding in de inleiding worden besproken. In hoofdstuk 5 wordt de werkgelegenheidsstructuur van werkzame personen, pendelaars en baanvinders onderling vergeleken. Tenslotte wordt in hoofdstuk 6 op basis van de in dit rapport gepresenteerde gegevens ingegaan op de sector-, beroepen en opleidingenindelingen die in de toekomst zouden kunnen worden gehanteerd bij het genereren van provinciale en regionale arbeidsmarktinformatie uit de EBB. 


\section{WERKGELEGENHEIDSSTRUCTUUR}

\subsection{Inleiding}

De regionale werkgelegenheidsontwikkeling hangt doorgaans nauw samen met de bedrijfssectorenstructuur. Als in een regio de landelijke groeisectoren zijn oververtegenwoordigd, zal de regionale werkgelegenheidsontwikkeling waarschijnlijk gunstig zijn, al is het natuurlijk wel mogelijk dat een landelijke groeisector in een bepaalde regio minder gunstige werkgelegenheidsperspectieven biedt. Daarentegen zal de werkgelegenheidsontwikkeling in een provincie achter blijven bij de landelijke ontwikkeling als de 'zwakkere' bedrijfssectoren in de desbetreffend provincie zijn oververtegenwoordigd. Daarbij moet ook worden bedacht dat de bedrijfssectorenstructuur van invloed is op de beroepenstructuur van de werkgelegenheid, terwijl de opleidingenstructuur van de werkgelegenheid in belangrijke mate door de sector- en beroepenstructuur wordt bepaald.

In dit hoofdstuk zal een beeld worden geschetst van de werkgelegenheidsstructuur van de in de provincie Noord-Holland werkzame personen, achtereenvolgens verbijzonderd naar branche, beroep en opleiding. Daarbij zal ook telkens informatie worden gepresenteerd die is verbijzonderd naar RBA-gebied. Vervolgens wordt de leeftijdsstructuur van de werkgelegenheid besproken en wordt nader ingegaan op de positie van vrouwen op de arbeidsmarkt. In de afsluitende paragraaf worden de belangrijkste conclusies op een rijtje gezet.

\subsection{Sectorstructuur}

Tabel 2.1 geeft een beeld van de spreiding van de werkgelegenheid over de verschillende bedrijfsklassen ${ }^{5}$. Uit de tabel blijkt dat van het totaal aantal werkzame personen in NoordHolland $9 \%$ werkzaam is in de bedrijfsklasse 'Openbaar bestuur, defensie, wettelijke sociale verzekering' $(90)^{6}$. Het gaat hierbij om in totaal bijna 75.000 werkenden. In de bedrijfsklasse 'Gezondheids- en veterinaire diensten' (93) is eveneens $9 \%$ van het totaal aantal werkenden in de provincie werkzaam. Verder zijn in de bedrijfsklassen 'Groothandel' (61-64) en 'Detailhandel' (65-66) respectievelijk $7 \%$ en $8 \%$ van het totaal aantal werkenden werkzaam. In de bedrijfsklasse 'Handel onroerend goed, zakelijke dienstverlening en verhuur roerende goederen' (83-85) is eveneens $7 \%$ van de werkzame personen in Noord-Holland werkzaam. In de industriële bedrijfsklassen (2-3) werkt in totaal ongeveer $15 \%$ van de arbeidskrachten. Daarbinnen is de bedrijfsklasse 'Papier- en grafische industrie' $(26,27)$ het grootste. Andere belangrijke bedrijfsklassen in de industrie zijn ' Voedings- en genotmiddelenindustrie' (20-21), 'Chemie' (29-31) en 'Basismetaalindustrie' (33).

5. In bijlage A wordt een overzicht gegeven van de in dit rapport onderscheiden bedrijfsklassen. Daarbij vormt de Standaard Bedrijfsindeling (SBI) het uitgangspunt, waarbij enkele bedrijfsklassen worden samengevoegd.

6. In dit rapport zal telkens bij de verschillende bedrijfs-, beroeps- en opleidingscategorieën tussen haakjes de bijbehorende code worden aangegeven. 
Tabel 2.1. Aantal en percentage werkenden per bedrijfsklasse in Noord-Holland, gemiddelde 1989-1991

\begin{tabular}{llc}
\hline Code $\quad$ bedrijfsklasse & aantal $\%$ \\
\hline
\end{tabular}

Kleine marges

$\begin{array}{llrl}0 & \text { Landbouw, visserij en bosbouw } & 22.500 & 3 \\ 20-21 & \text { Voedings- en genotmiddelenindustrie } & 18.000 & 2 \\ 26,27 & \text { Papier- en grafische industrie } & 26.000 & 3 \\ 29-31 & \text { Chemie } & 14.500 & 2 \\ 33 & \text { Basismetaalindustrie } & 16.000 & 2 \\ 34 & \text { Metaalprodukten (excl. machines e.d) } & 10.000 & 1 \\ 36 & \text { Elektrotechnische industrie } & 12.000 & 1 \\ 37 & \text { Transportmiddelenindustrie } & 10.000 & 1 \\ 5 & \text { Bouwnijverheid en -installatiebedrijven } & 27.000 & 3 \\ 61-64 & \text { Groothandel } & 58.500 & 7 \\ 65-66 & \text { Detailhandel } & 71.000 & 8 \\ 67 & \text { Hotels, restaurants, cafés e.d. } & 28.000 & 3 \\ 68 & \text { Reparatiebedrijven voor gebruiksgoederen } & 11.500 & 1 \\ 71-74 & \text { Weg- en watervervoer } & 26.500 & 3 \\ 75 & \text { Luchtvaart } & 24.000 & 3 \\ 76-77 & \text { Hulpbedrijven van het vervoer en communicatiebedrijven } & 23.000 & 3 \\ 81 & \text { Bankwezen } & 37.500 & 4 \\ 82 & \text { Verzekeringswezen } & 12.000 & 1 \\ 83-85 & \text { Handel onroerend goed, zakelijke dienstverlening } & & \\ & \text { en verhuur roerende goederen } & 62.000 & 7 \\ 90 & \text { Openbaar bestuur, defensie, wettelijke sociale verzekering } & 74.000 & 9 \\ 92 & \text { Onderwijs } & 52.000 & 6 \\ 93 & \text { Gezondheids- en veterinaire diensten } & 74.500 & 9 \\ 94 & \text { Maatschappelijke dienstverlening } & 39.500 & 5 \\ 95 & \text { Sociaal-culturele en culturele instellingen } & 23.000 & 3 \\ 98 & \text { Overige dienstverlenende bedrijven } & 19.000 & 2\end{array}$

Redelijke marges

$\begin{array}{llrl}35 & \text { Machine-industrie } & 9.000 & 1 \\ 38,39 & \text { Instrumenten-, optische en overige industrie } & 9.500 & 1 \\ 40 & \text { Openbare nutsbedrijven } & 7.500 & 1 \\ 96 & \text { Sport en recreatie } & 6.000 & 1 \\ 91,97 & \text { Religieuze en overige sociale organisaties } & 8.500 & 1\end{array}$

Grote marges

$1 \quad$ Delfstoffenwinning

22-24 Kleding- en schoenenindustrie

25,32 Hout- en bouwmaterialenindustrie

$28 \quad$ Aardolie- en steenkoolverwerking

$\begin{array}{lrl}\text { Totaal waargenomen } & 846.500 & 100\end{array}$

$\begin{array}{lrl}\text { Totaal } & 850.000 & 100\end{array}$

Bron: CBS

In tabel 2.2 komen de verschillen in de bedrijfsklassenstructuur tussen de vier RBA-gebieden binnen de provincie Noord-Holland tot uiting. Uit de tabel blijkt dat de bedrijfsklassen 'Elektrotechnische industrie' (36) en 'Sociaal-culturele en culturele instellingen' (95) relatief sterk zijn vertegenwoordigd in GV. Bij de laatstgenoemde bedrijfsklasse hangt dit samen met de vestiging van het publieke omroepwezen in en rond Hilversum. De bedrijfsklassen 'Landbouw, visserij en bosbouw' (0), 'Detailhandel' (65-66) en 'Openbaar bestuur, defensie, wettelijke sociale verzekering' (90) zijn verhoudingsgewijs sterk vertegenwoordigd in NHN. De oververtegenwoordiging van de laatstgenoemde bedrijfsklasse kan worden toegeschreven aan 
de Nederlandse Marinevestiging in Den Helder. In AZW is een relatief groot aantal arbeidskrachten werkzaam in de bedrijfsklasse 'Bankwezen' (81), hetgeen de concentratie van de hoofdvestigingen van enkele grote banken weerspiegelt. De bedrijfsklassen 'Luchtvaart' (75) en 'Basismetaalindustrie' (33) zijn relatief sterk vertegenwoordigd in KAM. Dit hangt nauw samen met de aanwezigheid van respectievelijk Schiphol en het Hoogovenconcern.

Tabel 2.2. Percentage werkenden per bedrijfsklasse in Noord-Holland, verbijzonderd naar RBA-gebied, gemiddelde 1989-1991

\begin{tabular}{|c|c|c|c|c|c|c|}
\hline \multirow[b]{2}{*}{ Code } & \multirow[b]{2}{*}{ bedrijfsklasse } & \multirow[b]{2}{*}{ GV } & \multicolumn{2}{|c|}{ werk-RBA } & \multirow[b]{2}{*}{ KAM } & \multirow[b]{2}{*}{ totaal } \\
\hline & & & NHN & $A Z W$ & & \\
\hline 0 & Landbouw, visserij en bosbouw & . & 9 & $1 *$ & 3 & 3 \\
\hline 1 & Delfstoffenwinning & . & $\therefore$ & $\dot{ }$ & $\therefore$ & \\
\hline $20-21$ & Voedings- en genotmiddelenindustrie & . & $3^{*}$ & 2. & $2^{*}$ & 2. \\
\hline $22-24$ & Kleding- en schoenenindustrie & . & . & $1{ }^{*}$ & . & $1^{*}$ \\
\hline 25,32 & Hout- en bouwmaterialenindustrie & . & $\therefore$ & $0^{*}$ & . & $0^{\circ}$ \\
\hline 26,27 & Papier- en grafische industrie & - & $2^{*}$ & 4 & 2 & 3 \\
\hline 28 & Aardolie- en steenkoolverwerking & 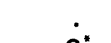 & & & $\therefore$ & \\
\hline $29-31$ & Chemie & $6^{*}$ & $2^{*}$ & 1 & $1^{*}$ & 2 \\
\hline 33 & Basismetaalindustrie & . & $\therefore$ & . & 7 & 2 \\
\hline 34 & Metaalprodukten (excl. machines e.d) & . & $1^{*}$ & $1^{*}$ & $1^{*}$ & 1 \\
\hline 35 & Machine-industrie & . & . & 1. & $1^{*}$ & 1 \\
\hline 36 & Elektrotechnische industrie & 7 & . & $1^{*}$ & $1^{*}$ & 1 \\
\hline 37 & Transportmiddelenindustrie & . & . & $1^{\circ}$ & 3 & 1 \\
\hline 38,39 & Instrumenten-, optische en overige industrie & . & $2^{*}$ & $1^{\circ}$ & $1^{*}$ & 1 \\
\hline 40 & Openbare nutsbedrijven & 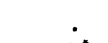 & $1^{*}$ & $1^{*}$ & $1^{\circ}$ & 1 \\
\hline 5 & Bouwnijverheid en -installatiebedrijven & $3^{*}$ & 4 & 3 & 4 & 3 \\
\hline $61-64$ & Groothandel & 9 & 5 & 7 & 8 & 7 \\
\hline $65-66$ & Detailhandel & 9 & 11 & 8 & 8 & 8 \\
\hline 67 & Hotels, restaurants, cafés e.d. & 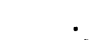 & 3 & 4 & 3 & 3 \\
\hline 68 & Reparatiebedrijven voor gebruiksgoederen & $4^{*}$ & $2^{*}$ & $1^{*}$ & $1^{*}$ & 1 \\
\hline $71-74$ & Weg- en watervervoer & . & $2^{*}$ & 3 & 3 & 3 \\
\hline 75 & Luchtvaart & . & . & . & 10 & 3 \\
\hline \multirow[t]{2}{*}{$76-77$} & Hulpbedrijven van het vervoer & & & & & \\
\hline & en communicatiebedrijven & $\cdot$ & 2" & 3 & 3 & 3 \\
\hline 81 & Bankwezen & . & $2^{*}$ & 7 & $2^{*}$ & 4 \\
\hline 82 & Verzekeringswezen & . & . & 2 & . & 1 \\
\hline $83-85$ & $\begin{array}{l}\text { Handel onroerend goed, zakelijke dienstverlening } \\
\text { en verhuur roerende goederen }\end{array}$ & 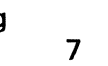 & 4 & 9 & 6 & 7 \\
\hline \multirow[t]{2}{*}{90} & Openbaar bestuur, defensie, & & & & & \\
\hline & wettelijke sociale verzekering & $6^{*}$ & 13 & 9 & 6 & 9 \\
\hline 92 & Onderwijs & $6^{*}$ & 6 & 7 & 4 & 6 \\
\hline 93 & Gezondheids- en veterinaire diensten & 9 & 8 & 9 & 8 & 9 \\
\hline 94 & Maatschappelijke dienstverlening & $4^{*}$ & 5 & 5 & 5 & 5 \\
\hline 95 & Sociaal-culturele en culturele instellingen & 9 & $1^{*}$ & 3 & $1^{\circ}$ & 3 \\
\hline 96 & Sport en recreatie & . & . & $1^{*}$ & . & 1 \\
\hline 91,97 & Religieuze en overige sociale organisaties & & $1^{*}$ & 1 & . & 1 \\
\hline \multirow[t]{2}{*}{98} & Overige dienstverlenende bedrijven & $3^{*}$ & $2^{*}$ & 2 & $2^{*}$ & 2 \\
\hline & Totaal & 0.500 & 146.000 & 402.500 & 230.500 & 850.000 \\
\hline
\end{tabular}

Bron: CBS

\subsection{Beroepenstructuur}

De bedrijfssectorenstructuur is, zoals gezegd, in belangrijke mate bepalend voor de beroepenstructuur van de werkgelegenheid. De beroepen zijn daarbij ingedeeld volgens de ROAberoepenclassificatie 1990. De classificatie is een viercijferige code, waarbij het eerste cijfer een onderscheid maakt naar beroepssectoren, die zijn vastgesteld op basis van de opleidings- 
richting van de werkenden. Het tweede cijfer (de beroepstakken) geeft een verdere differentiatie naar de branche waarin de beroepsbeoefenaren hoofdzakelijk werkzaam zijn. Het derde cijfer geeft het (mediaan) opleidingsniveau van de werkenden aan (de beroepssegmenten). Met het vierde cijfer, hetgeen slechts een volgnummer is, worden de beroepsklassen onderscheiden (zie ook Van de Loo, Dekker en De Grip, 1992).

In tabel 2.3 wordt een beeld gegeven van de beroepenstructuur van de werkgelegenheid in de provincie Noord-Holland'. Daarbij is tevens aangegeven in hoeverre de beroepenstructuur afwijkt van de landelijke werkgelegenheidsstructuur ${ }^{8}$. Uit de tabel blijkt dat de beroepenstructuur in de provincie Noord-Holland slechts in geringe mate afwijkt van het landelijke beeld. In de 'Agrarische beroepen' (2) is de werkgelegenheid in de provincie NoordHolland 2\%-punten lager dan de landelijke werkgelegenheid. Ook de werkgelegenheid in de technische beroepen is in de provincie Noord-Holland ondervertegenwoordigd. In Noord-Holland werkt $21 \%$ van het totaal aantal arbeidskrachten in de technische beroepen (3), terwijl dit percentage voor Nederland $27 \%$ bedraagt. De verder verbijzonderde cijfers laten zien dat het percentage arbeidskrachten dat werkzaam is in de 'Lagere bouw- en installatieberoepen' (391) $2 \%$-punten lager is dan gemiddeld voor Nederland. In de economisch-administratieve beroepen (6) is $37 \%$ van de totale werkzame personen in Noord-Holland werkzaam. Van de werkzame personen in Nederland werkt slechts $32 \%$ in de economisch-administratieve beroepen (6). Daarbij is de werkgelegenheid voor de 'Boekhoudkundige, belasting- en bankemployées' (6124) $2 \%$-punten hoger dan de landelijke werkgelegenheid, hetgeen een weerspiegeling vormt van het grote belang van de banksector en de zakelijke dienstverlening voor de provincie Noord-Holland.

In tabel 2.4 wordt een beeld geschetst van de tien beroepssegmenten die in vergelijking met het landelijk gemiddelde in de provincie Noord-Holland relatief sterk zijn vertegenwoordigd. Ook hier komt duidelijk het belang van de luchthaven Schiphol naar voren voor de werkgelegenheid. Bijna één kwart van de totale Nederlands werkgelegenheid in de 'Lucht- en overige transportberoepen' (43) is geconcentreerd in Noord-Holland. Dit terwijl in de provincie slechts $15 \%$ van de totale Nederlandse werkzame personen werkzaam is. Ook de 'Middelbare politie-, brandweeren bewakingsberoepen' (912) zijn sterk vertegenwoordigd in de provinciale werkgelegenheid. Het betreft hier overigens beroepssegmenten waarvan de werkgelegenheidssituatie slechts in geringe mate afhankelijk is van conjuncturele schommelingen (zie ROA, 1993). Verder zijn de 'Middelbare sociaal-culturele beroepen' (702), 'Telefonisten, balie-employées, enquêteurs e.d.' (6126), 'Secretaressen, typisten' (6122) en de 'Culturele beroepen' (1) relatief sterk zijn vertegenwoordigd in de provincie Noord-Holland.

7. In bijlage A wordt een overzicht gegeven van de in dit rapport onderscheiden beroepssegmenten. Het uitgangspunt vormen de beroepssegmenten van de ROA-beroepenclassificatie. Daarbij is echter een aantal beroepssegmenten samengevoegd tot beroepstakken of beroepssectoren. Aan de andere kant worden enkele beroepssegmenten verder verbijzonderd naar beroepsklasse.

8. De gegevens per beroepssegment voor Nederland zijn helaas niet in het kader van dit project verzameld. Wel zijn dezelfde gegevens beschikbaar vanuit een eerdere ROA-studie (zie Hoevenberg, Willems en De Grip, 1993). Doordat de in dit rapport gehanteerde beroepenclassificatie echter enigszins afwijkt van de beroepenindeling waarvoor de landelijke gegevens beschikbaar zijn, kunnen er afrondfouten optreden bij het bepalen van de aantallen werkzame personen per beroepssegment voor geheel Nederland. 
Tabel 2.3. Aantal en percentage werkenden per beroepssegment in Noord-Holland en in geheel Nederland, gemiddelde 1989-1991

\begin{tabular}{llcl}
\hline Code beroepssegment & $\begin{array}{c}\text { Noord-Holland } \\
\text { aantal } \%\end{array}$ & $\begin{array}{c}\text { Nederland } \\
\text { aantal }\end{array} \%$ \\
\hline
\end{tabular}

Kleine marges

$\begin{array}{llrrrr}0 & \text { Pedagogische beroepen } & 44.500 & 5 & 296.000 & 5 \\ 1 & \text { Culturele beroepen } & 16.000 & 2 & 76.500 & 1 \\ 2 & \text { Agrarische beroepen } & 26.500 & 3 & 284.000 & 5 \\ 302 & \text { Middelbare technische, ambachts- en industrieberoepen } & 53.000 & 6 & 301.500 & 5 \\ 331 & \text { Lagere hout- en papierberoepen } & 10.000 & 1 & 131.500 & 2 \\ 341 & \text { Lagere grafische beroepen } & 10.500 & 1 & 55.500 & 1 \\ 361 & \text { Lagere metaalberoepen } & 32.500 & 4 & 254.500 & 4 \\ 372 & \text { Middelbare elektrotechnische beroepen } & 14.000 & 2 & 103.500 & 2 \\ 391 & \text { Lagere bouw- en installatieberoepen } & 15.000 & 2 & 223.000 & 4 \\ 40 & \text { Transportberoepen } & 20.000 & 2 & 118.000 & 2 \\ 42 & \text { Rail- en wegtransportberoepen } & 20.500 & 2 & 165.000 & 3 \\ 5021 & \text { Gediplomeerde verpleegkundigen, verloskundigen } & 22.000 & 3 & 117.500 & 2 \\ 5022 & \text { Leerling-verpleegkundigen, zieken- en kraamverzorgenden } & 14.500 & 2 & 103.500 & 2 \\ 503 & \text { Hogere medische en paramedische beroepen } & 20.000 & 2 & 110.000 & 2 \\ 603 & \text { Hogere economisch-administratieve beroepen } & 15.500 & 2 & 99.000 & 2 \\ 6122 & \text { Secretaressen, typisten } & 29.500 & 3 & 141.000 & 2 \\ 6124 & \text { Boekhoudkundige, belasting- en bankemployées } & 67.000 & 8 & 327.000 & 6 \\ 6125 & \text { Commercieel-administratieve employées } & 60.500 & 7 & 319.000 & 6 \\ 6126 & \text { Telefonisten, balie-employées, enquêteurs e.d. } & 16.000 & 2 & 76.000 & 1 \\ 6131 & \text { Systeemanalisten, -programmeurs en -beheerders } & 19.500 & 2 & 112.500 & 2 \\ 621 & \text { Lagere commerciële beroepen } & 39.000 & 5 & 245.500 & 4 \\ 622 & \text { Middelbare commerciële beroepen } & 35.500 & 4 & 281.500 & 5 \\ 703 & \text { Hogere sociaal-culturele beroepen } & 24.000 & 3 & 134.500 & 2 \\ 811 & \text { Lagere horecaberoepen } & 25.000 & 3 & 124.000 & 2 \\ 812 & \text { Middelbare horecaberoepen } & 10.000 & 1 & 58.500 & 1 \\ 8211 & \text { Portiers, schoonmaak- e.a. lager dienstverlenend personeel } & 28.000 & 3 & 149.500 & 3 \\ 8212 & \text { Kinder-, gezins-, bejaardenverzorgenden } & 16.000 & 2 & 114.500 & 2 \\ 912 & \text { Middelbare politie-, brandweer- en bewakingsberoepen } & 13.500 & 2 & 57.000 & 1\end{array}$

\section{Redelijke marges}

$\begin{array}{ll}301 & \text { Lagere technische, ambachts- en industrieberoepen } \\ 303 & \text { Hogere technische, ambachts- en industrieberoepen } \\ 311 & \text { Lagere voedings- en genotmiddelenberoepen } \\ 321 & \text { Lagere textielberoepen } \\ 362 & \text { Middelbare metaalberoepen } \\ 43 & \text { Lucht- en overige transportberoepen } \\ 5023-5025 & \text { Dokters-, tandarts-, apothekersassistenten en andere paramedici } \\ 6111 & \text { Postdistributiepersoneel } \\ 6121 & \text { Leidinggevend administratief personeel } \\ 6132 & \text { Economen, accountants e.a. economische specialisten } \\ 633 & \text { Hogere bestuurlijke en juridische beroepen } \\ 702 & \text { Middelbare sociaal-culturele beroepen } \\ 822 & \text { Middelbare verzorgende beroepen } \\ 922 & \text { Middelbare militaire beroepen }\end{array}$

$\begin{array}{llll}6.000 & 1 & 53.000 & 1 \\ 7.000 & 1 & 54.000 & 1 \\ 9.000 & 1 & 69.000 & 1 \\ 5.500 & 1 & 50.500 & 1 \\ 7.500 & 1 & 58.000 & 1 \\ 7.000 & 1 & 29.000 & 1 \\ 9.000 & 1 & 59.000 & 1 \\ 8.000 & 1 & 41.500 & 1 \\ 7.000 & 1 & 43.000 & 1 \\ 8.000 & 1 & 50.500 & 1 \\ 8.500 & 1 & 59.000 & 1 \\ 7.000 & 1 & 31.500 & 1 \\ 5.000 & 1 & 33.500 & 1 \\ 5.500 & 1 & 38.000 & 1\end{array}$

\section{Grote marges}

$\begin{array}{ll}351 & \text { Lagere chemische beroepen } \\ 363 & \text { Hogere metaalberoepen } \\ 371 & \text { Lagere elektrotechnische beroepen } \\ 373 & \text { Hogere elektrotechnische beroepen } \\ 381 & \text { Lagere bouwmaterialen-, glas- en aardewerkberoepen } \\ 392 & \text { Middelbare bouw- en installatieberoepen } \\ 393 & \text { Hogere bouw- en installatieberoepen } \\ 41 & \text { Maritieme e.a. waterwegtransportberoepen } \\ 6112 & \text { Datatypisten, computeroperators } \\ 6123 & \text { Bibliotheek- en archiefmedewerkers }\end{array}$

Totaal waargenomen

$\begin{array}{rrrr}3.500 & 0 & 28.500 & 1 \\ 2.500 & 0 & 14.500 & 0 \\ 3.500 & 0 & 29.000 & 1 \\ 2.000 & 0 & 19.000 & 0 \\ 3.500 & 0 & 40.000 & 1 \\ 2.500 & 0 & 22.500 & 0 \\ 3.000 & 0 & 28.000 & 0 \\ 2.500 & 0 & 16.000 & 0 \\ 3.500 & 0 & 20.500 & 0 \\ & & & 0 \\ 47.500 & 100 & 5.481 .500 & 97 \\ & & & \\ 50.000 & 100 & 5.660 .000 & 100\end{array}$

Totaal

$850.000100 \quad 5.660 .000100$ 
Tabel 2.4. Beroepssegmenten die relatief sterk in Noord-Holland zijn vertegenwoordigd, gemiddelde 1989-1991

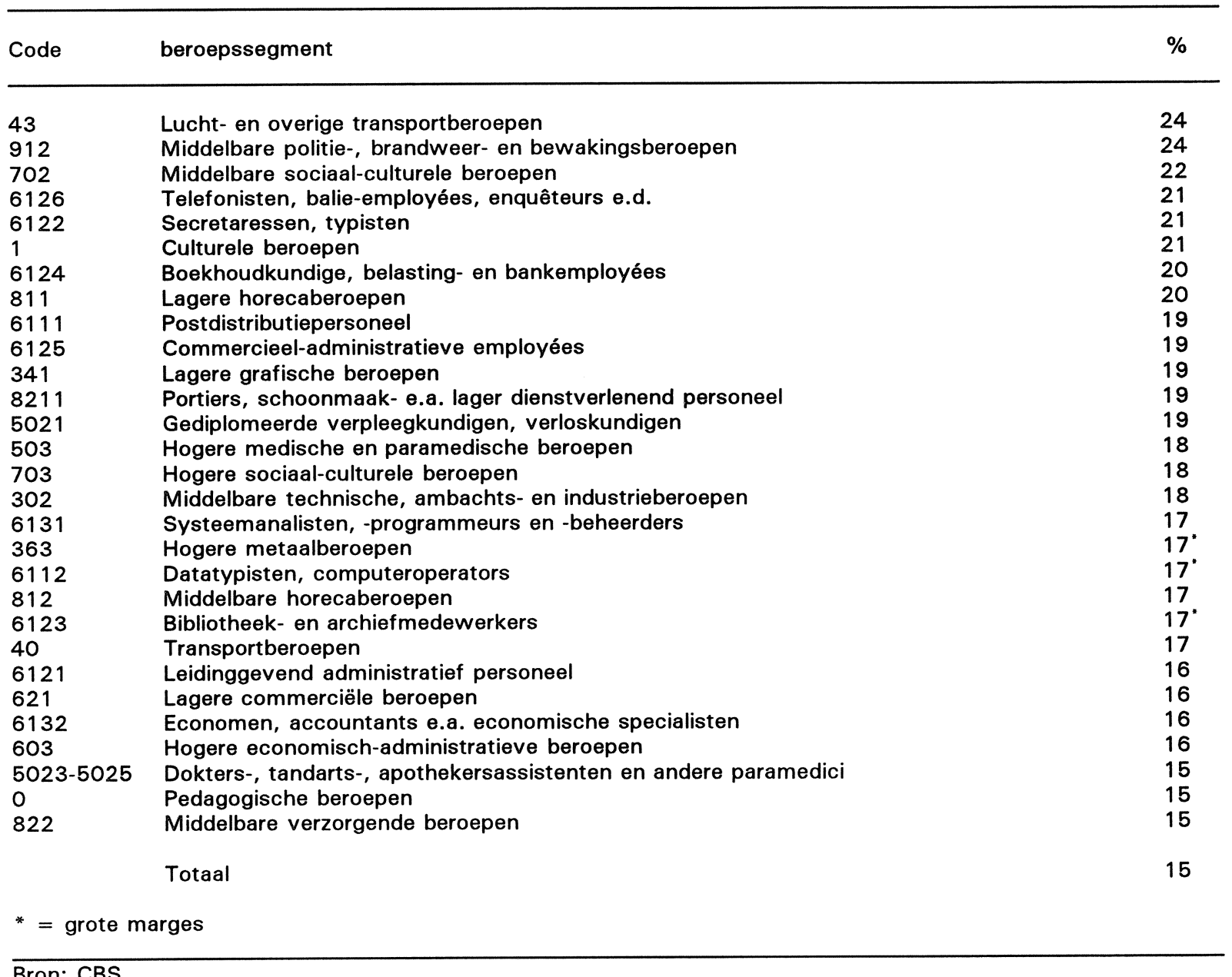

Bron: CBS

Tabel 2.5 geeft een overzicht van de verschillen in de beroepenstructuur tussen de vier RBAgebieden binnen de provincie Noord-Holland. In NHN is een verhoudingsgewijs groot aantal mensen werkzaam in de 'Agrarische beroepen' (2). Dit hangt vanzelfsprekend samen met sterke vertegenwoordiging van de bedrijfsklasse 'Landbouw, visserij en bosbouw' $(0)$ in dit RBAgebied. In AZW zijn de economisch-administratieve beroepen (6) relatief sterk vertegenwoordigd. De technische beroepen (3) zijn verhoudingsgewijs sterk vertegenwoordigd in KAM. Daarbij is in KAM een verhoudingsgewijs groot aantal beroepsbeoefenaren werkzaam in de 'Lagere metaalberoepen' (361). Dit heeft te maken met de sterke vertegenwoordiging van de 'Basismetaalindustrie' (33) in dit RBA-gebied, als gevolg van de aanwezigheid van Hoogovens. Daarbij moet worden bedacht dat het bij de laatstgenoemde beroepen gaat om beroepen waarvan de werkgelegenheidssituatie in sterke mate wordt beïnvloed door conjuncturele schommelingen (zie ROA, 1993). 
Tabel 2.5. Percentage werkenden per beroepssegment in Noord-Holland, verbijzonderd naar RBA-gebied, gemiddelde 1989-1991

\begin{tabular}{|c|c|c|c|c|c|c|}
\hline \multirow[b]{2}{*}{ Code } & \multirow[b]{2}{*}{ beroepssegment } & \multirow[b]{2}{*}{ GV } & \multicolumn{2}{|c|}{ werk-RBA } & \multirow[b]{2}{*}{ KAM } & \multirow[b]{2}{*}{ totaal } \\
\hline & & & NHN & AZW & & \\
\hline 0 & Pedagogische beroepen & $5^{*}$ & 6 & 6 & 4 & 5 \\
\hline 1 & Culturele beroepen & $4^{*}$ & & 2 & $1^{*}$ & 2 \\
\hline 2 & Agrarische beroepen & . & 10 & 1 & 3. & 3 \\
\hline $\begin{array}{l}301 \\
302\end{array}$ & $\begin{array}{l}\text { Lagere technische, ambachts- en industrieberoepen } \\
\text { Middelbare technische, ambachts- en }\end{array}$ & . & . & $1^{*}$ & $1^{*}$ & 1 \\
\hline 302 & industrieberoepen & 8 & 5 & 6 & 7 & 6 \\
\hline 303 & Hogere technische, ambachts- en industrieberoepen & . & & $1^{*}$ & . & 1 \\
\hline 311 & Lagere voedings- en genotmiddelenberoepen & . & $1^{*}$ & $1^{*}$ & $1^{*}$ & 1 \\
\hline 321 & Lagere textielberoepen & . & $\cdot$ & $0^{*}$ & $\therefore$ & 1 \\
\hline 331 & Lagere hout- en papierberoepen & . & 2 & $1^{*}$ & $i$ & 1 \\
\hline 341 & Lagere grafische beroepen & . & . & 1 & $1^{\circ}$ & 1 \\
\hline 351 & Lagere chemische beroepen & & & & & $0 *$ \\
\hline 361 & Lagere metaalberoepen & $3^{*}$ & 4 & 2 & 7 & 4 \\
\hline 362 & Middelbare metaalberoepen & . & $1^{*}$ & $\overline{1}$ & $1 *$ & 1 \\
\hline 363 & Hogere metaalberoepen & . & . & . & . & $0^{\circ}$ \\
\hline 371 & Lagere elektrotechnische beroepen & & & . & & $0^{\circ}$ \\
\hline 372 & Middelbare elektrotechnische beroepen & $3^{*}$ & $1^{*}$ & 1 & $2^{*}$ & 2 \\
\hline $37 \overline{3}$ & Hogere elektrotechnische beroepen & . & . & . & . & $0^{\circ}$ \\
\hline 381 & Lagere bouwmaterialen-, glas- en aardewerkberoepen & . & & . & & $0^{\circ}$ \\
\hline 391 & Lagere bouw- en installatieberoepen & . & 2" & 2 & $\dot{2}$ & 2 \\
\hline 392 & Middelbare bouw- en installatieberoepen & . & . & . & . & 0 \\
\hline 393 & Hogere bouw-en installatieberoepen & . &. & . & . & $0^{\circ}$ \\
\hline 40 & Transportberoepen & . & $2^{*}$ & 2 & 3 & 2 \\
\hline 41 & Maritieme e.a. waterwegtransportberoepen & . & & . & . & . \\
\hline 42 & Rail- en wegtransportberoepen & . & $2^{*}$ & 2 & 2 & 2 \\
\hline 43 & Lucht- en overige transportberoepen & . & & $1^{*}$ & $2^{*}$ & 1 \\
\hline 5021 & & . & $2^{*}$ & 2 & 3 & 3 \\
\hline 5022 & $\begin{array}{l}\text { Leerling-verpleegkundigen, zieken- en } \\
\text { kraamverzorgenden }\end{array}$ & . & $2^{*}$ & 1 & $2^{*}$ & 2 \\
\hline $5023-5025$ & Dokters-, tandarts-, apothekersassistenten & & & & & 2 \\
\hline & en andere paramedici & $\cdot$ & $1^{*}$ & $1^{*}$ & $1^{*}$ & 1 \\
\hline 503 & Hogere medische en paramedische beroepen & . & $2^{*}$ & 3 & $2^{*}$ & 2 \\
\hline 603 & Hogere economisch-administratieve beroepen & $\dot{.}$ & $1^{*}$ & 2 & $\overline{2}$ & 2 \\
\hline 6111 & Postdistributiepersoneel & . & . & 1. & $1 *$ & 1 \\
\hline 6112 & Datatypisten, computeroperators & . & . & $0^{*}$ & . & 0 \\
\hline 6121 & Leidinggevend administratief personeel & ${ }^{\circ}$ & & $1^{*}$ & . & 1 \\
\hline 6122 & Secretaressen, typisten & $5^{*}$ & $\dot{2}$ & 4 & $\dot{3}$ & 3 \\
\hline 6123 & Bibliotheek- en archiefmedewerkers & & & $0^{*}$ & & 0 \\
\hline 6124 & Boekhoudkundige, belasting- en bankemployées & 7 & 7 & 9 & 6 & 8 \\
\hline 6125 & Commercieel-administratieve employées & $6^{*}$ & 6 & 8 & 7 & 7 \\
\hline 6126 & Telefonisten, balie-employées, enquêteurs e.d. & . & . & 2 & $2^{*}$ & 2 \\
\hline 6131 & Systeemanalisten, -programmeurs en -beheerders & ${ }^{\circ}$ & $\cdot$ & 3 & 3 & 2 \\
\hline 6132 & Economen, accountants e.a. economische specialisten & & & $1^{*}$ & $1^{*}$ & 1 \\
\hline 621 & Lagere commerciële beroepen & $5^{*}$ & 6 & 4 & 4 & 5 \\
\hline 622 & Middelbare commerciële beroepen & $5^{*}$ & 5 & 4 & 4 & 4 \\
\hline 633 & Hogere bestuurlijke en juridische beroepen & . & . & 1 & . & 1 \\
\hline 702 & Middelbare sociaal-culturele beroepen & ${ }^{\circ}$ & & $i^{*}$ & . & 1 \\
\hline 703 & Hogere sociaal-culturele beroepen & & $i *$ & 4 & 2 & 3 \\
\hline 811 & Lagere horecaberoepen & $3^{*}$ & 3 & 3 & 3 & 3 \\
\hline 812 & Middelbare horecaberoepen & . & $1^{*}$ & 1 & $1^{*}$ & 1 \\
\hline 8211 & Portiers, schoonmaak- e.a. lager dienstverlenend & $3^{*}$ & $3 *$ & 3 & 4 & 3 \\
\hline 8212 & $\begin{array}{l}\text { personeel } \\
\text { Kinder-, gezins-, bejaardenverzorgenden }\end{array}$ & . & $2^{*}$ & 2 & $\begin{array}{l}4 \\
2^{*}\end{array}$ & 2 \\
\hline 822 & Middelbare verzorgende beroepen & & & $0^{*}$ & & 1 \\
\hline 912 & Middelbare politie-, brandweer- en bewakingsberoepen & & & 2 & $i^{*}$ & 2 \\
\hline 922 & Middelbare militaire beroepen & & $3^{*}$ & . & . & 1 \\
\hline & Totaal & & 146.000 & 402.500 & 230.500 & 850.000 \\
\hline
\end{tabular}


In tabel B.1 van bijlage B wordt meer in detail een beeld geschetst van de voor de verschillende beroepssegmenten belangrijkste bedrijfssectoren ${ }^{9}$. De werkenden in de middelbare administratieve beroepen (6122-6125) zijn in relatief veel verschillende bedrijfssectoren werkzaam. Bij de overige beroepssegmenten is de relatie tussen het beroep dat men uitoefent en de bedrijfssector waarin men werkzaam is in de meeste gevallen nauwer. Wel blijkt dat ook de werkenden in de beroepssegmenten 'Middelbare technische, ambachts- en industrieberoepen' (302) en 'Portiers, schoonmaak- e.a. lager dienstverlenend personeel' (8211) in relatief veel verschillende bedrijfssectoren werkzaam zijn.

\subsection{Opleidingenstructuur}

Tabel 2.6 geeft een overzicht van de verdeling van de werkgelegenheid in de provincie NoordHolland over de verschillende opleidingstypen ${ }^{10}$. Daarbij is tevens aangegeven hoe deze cijfers zich verhouden tot de landelijke opleidingenstructuur van de werkgelegenheid ${ }^{11}$. Uit de tabel blijkt dat de werkzame personen in Noord-Holland relatief hoog geschoold (5-6) is. Het percentage werkenden met een opleiding op VBO-niveau ${ }^{12}$ (3) is $4 \%$-punten lager dan gemiddeld in Nederland, terwijl het aantal werkenden met een hogere opleiding (5-6) $2 \%$-punten hoger is. Het percentage werkenden met een technische opleiding op zowel VBO-niveau (331-339) als van het Middelbaar Beroepsonderwijs (MBO) (436-439) is $2 \%$-punten lager dan in de landelijke situatie. Het aantal werkenden met een afgeronde opleiding die gerekend wordt tot het heterogene opleidingstype 'Hoger onderwijs verzorgend' is daarentegen $2 \%$-punten hoger dan landelijk. Hetzelfde geldt overigens voor het opleidingstype 'Bovenbouw HAVO/VWO' (401). Deze laatste groep heeft mogelijk vooral betrekking op arbeidskrachten die het hoger onderwijs zonder diploma hebben verlaten.

9. In bijlage A wordt een overzicht gegeven van de in dit rapport onderscheiden bedrijfssectoren.

10. In bijlage $A$ wordt een overzicht gegeven van de in dit rapport onderscheiden opleidingstypen. Het uitgangspunt vormen de ROA-opleidingstypen, die zijn gebaseerd op de Standaard Opleiding Indeling (SOI) op 3-digitniveau. In dit onderzoek zijn de opleidingstypen binnen het Hoger Beroepsonderwijs (HBO) en het Wetenschappelijk Onderwijs (WO) samengevoegd met een verbijzondering naar een viertal hoofdrichtingen.

11. Evenals bij de beroepen zijn ook de gegevens per opleidingstype voor Nederland helaas niet in het kader van dit project verzameld. Derhalve wordt ook hier gebruik gemaakt van de beschikbare gegevens uit een eerdere ROA-studie (zie Hoevenberg, Willems en De Grip, 1993). Doordat de in dit rapport gehanteerde opleidingenclassificatie op HBO en WO-niveau echter enigszins afwijkt van de opleidingenindeling waarvoor de landelijke gegevens beschikbaar zijn, kunnen er bij de hoger opgeleiden afrondfouten optreden bij het bepalen van de aantallen werkzame personen per opleidingstype voor geheel Nederland.

12. Per 1 augustus 1992 is het Lager Beroepsonderwijs (LBO) vervangen door het Voorbereidend Beroepsonderwijs (VBO). 
Tabel 2.6. Aantal en percentage werkenden per opleidingstype in Noord-Holland en in geheel Nederland, gemiddelde 1989-1991

\begin{tabular}{|c|c|c|c|c|c|}
\hline \multirow{2}{*}{$\begin{array}{l}\text { Code } \\
\text { Kleine marges }\end{array}$} & \multirow[t]{2}{*}{ opleidingstype } & \multicolumn{2}{|c|}{$\begin{array}{l}\text { Noord-Holland } \\
\text { aantal } \%\end{array}$} & \multicolumn{2}{|c|}{$\begin{array}{l}\text { Nederland } \\
\text { aantal \% }\end{array}$} \\
\hline & & & & & \\
\hline $\begin{array}{l}0,1,2 \\
301 \\
321-329 \\
331-339 \\
361-369 \\
381-389 \\
401 \\
421-429 \\
436-439 \\
453,461-464 \\
451,454 \\
481,484,486 \\
491-494 \\
5,6 \text { Verzorgend } \\
5,6 \text { Technisch } \\
5,6 \text { Economisch }\end{array}$ & $\begin{array}{l}\text { Basisonderwijs } \\
\text { MAVO en onderbouw HAVO/VWO } \\
\text { VBO agrarisch } \\
\text { VBO technisch } \\
\text { VBO economisch-administratief } \\
\text { VBO verzorgend } \\
\text { Bovenbouw HAVO/VWO } \\
\text { MBO agrarisch } \\
\text { MBO technisch } \\
\text { MBO economisch-administratief } \\
\text { MBO verpleging en ziekenverzorging } \\
\text { MBO verzorgend } \\
\text { MBO politie en defensie } \\
\text { Hoger onderwijs verzorgend } \\
\text { Hoger onderwijs technisch } \\
\text { Hoger onderwijs economisch }\end{array}$ & $\begin{array}{r}89.000 \\
64.000 \\
10.000 \\
57.000 \\
21.000 \\
28.000 \\
56.000 \\
11.000 \\
84.000 \\
109.000 \\
29.000 \\
27.000 \\
15.000 \\
120.000 \\
37.000 \\
48.000\end{array}$ & $\begin{array}{r}10 \\
7 \\
1 \\
7 \\
2 \\
3 \\
7 \\
1 \\
10 \\
13 \\
3 \\
3 \\
2 \\
14 \\
4 \\
6\end{array}$ & $\begin{array}{r}597.000 \\
396.000 \\
96.000 \\
518.000 \\
134.000 \\
211.000 \\
267.000 \\
121.000 \\
671.000 \\
667.000 \\
170.000 \\
211.000 \\
87.000 \\
670.000 \\
288.000 \\
291.000\end{array}$ & $\begin{array}{r}10 \\
7 \\
2 \\
9 \\
2 \\
4 \\
5 \\
2 \\
12 \\
12 \\
3 \\
4 \\
2 \\
12 \\
5 \\
5\end{array}$ \\
\hline \multicolumn{6}{|l|}{ Redelijke marges } \\
\hline $\begin{array}{l}341-349 \\
441-449 \\
466 \\
471 \\
483\end{array}$ & $\begin{array}{l}\text { VBO haven en vervoer } \\
\text { MBO haven en vervoer } \\
\text { MBO bestuurlijk } \\
\text { MBO sociaal-cultureel } \\
\text { MBO horeca en kappers }\end{array}$ & $\begin{array}{l}6.000 \\
7.000 \\
5.000 \\
6.000 \\
8.000\end{array}$ & $\begin{array}{l}1 \\
1 \\
1 \\
1 \\
1\end{array}$ & $\begin{array}{l}37.000 \\
44.000 \\
44.000 \\
41.000 \\
47.000\end{array}$ & $\begin{array}{l}1 \\
1 \\
1 \\
1 \\
1\end{array}$ \\
\hline \multicolumn{6}{|l|}{ Grote marges } \\
\hline $\begin{array}{l}391-394 \\
431 \\
452\end{array}$ & $\begin{array}{l}\text { VBO beveiliging en bewaking } \\
\text { MBO technisch laboratorium } \\
\text { MBO medisch laboratorium }\end{array}$ & 3.000 & i & $\begin{array}{r}7.000 \\
13.000 \\
21.000\end{array}$ & $\begin{array}{l}0 \\
0 \\
0\end{array}$ \\
\hline & Totaal waargenomen & 853.000 & 99 & 5.649 .000 & 98 \\
\hline & Totaal & 858.000 & 100 & 5.740 .000 & 100 \\
\hline
\end{tabular}

Bron: CBS

Tabel 2.7 geeft een overzicht van de opleidingstypen die in vergelijking met het landelijke beeld in de provincie Noord-Holland sterk zijn vertegenwoordigd. Uit de tabel blijkt dat ruim $20 \%$ van de werkzame personen in Nederland met een opleiding 'Bovenbouw HAVO/VWO' (401) werkzaam is in de provincie Noord-Holland. Zoals reeds uit de vorige tabel naar voren kwam, zijn ook de werkenden met een opleiding in het 'Hoger onderwijs verzorgend' in Noord-Holland relatief sterk vertegenwoordigd. Hetzelfde geldt overigens voor het opleidingstypen 'MBO politie en defensie' (491-494), 'MBO verpleging en ziekenverzorging' $(451,454)$ en 'MBO horeca en kappers (483). Daarnaast zijn op zowel VBO- als MBO-niveau in Noord-Holland verhoudingsgewijs veel arbeidskrachten werkzaam met een haven- of vervoersopleiding (341-349 en 441-449) of een economisch-administratieve (361-369 en 453,461-464) opleiding. 
Tabel 2.7. Opleidingstypen die relatief sterk in Noord-Holland zijn vertegenwoordigd, gemiddelde 1990-1991

\begin{tabular}{llr}
\hline Code & opleidingstype & $\%$ \\
\hline 401 & Bovenbouw HAVO/VWO & 21 \\
5,6 Verzorgend & Hoger onderwijs verzorgend & 18 \\
$491-494$ & MBO politie en defensie & 17 \\
451,454 & MBO verpleging en ziekenverzorging & 17 \\
483 & MBO horeca en kappers & 17 \\
5,6 Economisch & Hoger onderwijs economisch & 16 \\
$453,461-464$ & MBO economisch-administratief & 16 \\
$341-349$ & VBO haven en vervoer & 16 \\
301 & MAVO en onderbouw HAVO/VWO & 16 \\
$441-449$ & MBO haven en vervoer & 16 \\
$361-369$ & VBO economisch-administratief & 16 \\
$0,1,2$ & Basisonderwijs & 15 \\
471 & MBO sociaal-cultureel & 15 \\
& Totaal & 15 \\
\hline
\end{tabular}

Bron: CBS

De opleidingenstructuur wordt, zoals gezegd, in hoge mate bepaald door de sector- en beroepenstructuur. Dit is ook terug te vinden in de verschillen in de opleidingenstructuur tussen de verschillende RBA-gebieden in Noord-Holland. Uit tabel 2.8 blijkt dat in NHN het percentage werkenden met een VBO- (3) of MBO-opleiding (4) relatief hoog is, terwijl verhoudingsgewijs weinig werkenden een hogere opleiding (5-6) hebben afgerond. In AZW zijn de hoger opgeleiden (5-6) relatief sterk vertegenwoordigd.

In NHN zijn verhoudingsgewijs weinig beroepsbeoefenaren werkzaam met een opleiding 'Bovenbouw HAVO/VWO' (401) en 'Hoger onderwijs verzorgend' (5-6). Zoals mag worden verwacht op basis van de bedrijfsklassen- en de beroepenstructuur van de werkgelegenheid, is het aantal werkenden met een agrarische opleiding op MBO-niveau (421-429) daarentegen relatief groot in dit RBA-gebied. Hetzelfde geldt overigens voor het verzorgend onderwijs op VBO- (381-389) en MBO-niveau (481,484,486). Het 'Hoger onderwijs verzorgend' $(5-6)$ is relatief sterk vertegenwoordigd in $A Z W$, hetgeen onder andere zal samenhangen met de regionale en landelijke rol van de beide in dit RBA-gebied gevestigde academische ziekenhuizen. In KAM zijn daarentegen, evenals in NHN, relatief weinig beroepsbeoefenaren werkzaam met een opleiding 'Hoger onderwijs verzorgend' (5-6). De grote betekenis van de 'Basismetaalindustrie' in KAM heeft tot gevolgd dat het percentage werkenden met een opleiding 'MBO technisch' (436-439) of 'Hoger onderwijs technisch' (5-6) verhoudingsgewijs groot is ten opzichte van Noord-Holland als geheel, alhoewel deze opleidingstypen in de provincie vergeleken met het landelijk gemiddelde weer zijn ondervertegenwoordigd. 
Tabel 2.8. Percentage werkenden per opleidingstype in Noord-Holland, verbijzonderd naar RBA-gebied, gemiddelde 1989-1991

\begin{tabular}{|c|c|c|c|c|c|c|}
\hline \multirow[b]{2}{*}{ Code } & \multirow[b]{2}{*}{ opleidingstype } & \multirow[b]{2}{*}{ GV } & \multicolumn{2}{|c|}{ werk-RBA } & \multirow[b]{2}{*}{ KAM } & \multirow[b]{2}{*}{ totaal } \\
\hline & & & NHN & $A Z W$ & & \\
\hline $0,1,2$ & Basisonderwijs & 11 & 9 & 10 & 11 & 10 \\
\hline 301 & MAVO en onderbouw HAVO/VWO & 7 & 7 & 8 & 7. & 7 \\
\hline $321-329$ & VBO agrarisch & & $3^{*}$ & $1^{*}$ & $1^{*}$ & 1 \\
\hline $331-339$ & VBO technisch & $6^{*}$ & 8 & 6 & 8 & 7 \\
\hline $341-349$ & VBO haven en vervoer & . & . & $1^{*}$ & . & 1 \\
\hline $361-369$ & VBO economisch-administratief & . & $3^{*}$ & 2 & 2 & 2 \\
\hline $381-389$ & VBO verzorgend & . & 5 & 3 & 3 & 3 \\
\hline $391-394$ & VBO beveiliging en bewaking & & . & . & . & . \\
\hline 401 & Bovenbouw HAVO/VWO & $6^{*}$ & 4 & 8 & 6 & 7 \\
\hline $421-429$ & MBO agrarisch & . & 3 & $1^{*}$ & $1^{*}$ & 1 \\
\hline 431 & MBO technisch laboratorium & & & . & . & ${ }^{\circ}$ \\
\hline $436-439$ & MBO technisch & 10 & 11 & 8 & 12 & 10 \\
\hline $441-449$ & MBO haven en vervoer & . & . & $1^{*}$ & . & 1 \\
\hline 452 & MBO medisch laboratorium & & & 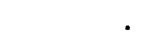 & & 0 \\
\hline $453,461-464$ & MBO economisch-administratief & 14 & 14 & 13 & 12 & 13 \\
\hline 451,454 & MBO verpleging en ziekenverzorging & . & 4 & 3 & 3 & 3 \\
\hline 466 & MBO bestuurlijk & . & . & $\therefore$ & . & 1 \\
\hline 471 & MBO sociaal-cultureel & 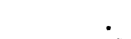 & - & $1^{*}$ & & 1 \\
\hline $481,484,486$ & MBO verzorgend & $4^{*}$ & 5 & 2 & 3 & 3 \\
\hline 483 & MBO horeca en kappers & . & 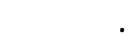 & $1^{*}$ & . & 1 \\
\hline $491-494$ & MBO politie en defensie & & 3 & 1 & $2^{*}$ & 2 \\
\hline 5,6 Verzorgend & Hoger onderwijs verzorgend & 15 & 11 & 17 & 10 & 14 \\
\hline 5,6 Technisch & Hoger onderwijs technisch & $4^{*}$ & $3^{\circ}$ & 4 & 6 & 4 \\
\hline \multirow[t]{2}{*}{ 5,6 Economisch } & Hoger onderwijs economisch & $6^{*}$ & $3^{*}$ & 7 & 5 & 6 \\
\hline & Totaal & 71.000 & 147.000 & 408.000 & 232.000 & 858.000 \\
\hline${ }^{*}=$ grote mar & & & & & & \\
\hline
\end{tabular}

Bron: CBS

In respectievelijk tabel B.2 en B.3 van bijlage B wordt per opleidingstype een overzicht gegeven van de belangrijkste bedrijfssectoren en beroepssegmenten waar degenen met de desbetreffende opleidingsachtergrond werkzaam zijn. Uit de tabellen komt naar voren dat de algemeen opgeleiden, zoals mocht worden verwacht, in relatief veel verschillende bedrijfssectoren en beroepssegmenten werkzaam zijn. Maar ook de technische opgeleiden op VBO- (331-339) en MBO-niveau (436-439) zijn werkzaam in uiteenlopende bedrijfssectoren en beroepssegmenten. Zoals verwacht, is dit ook het geval bij de werkenden die 'MBO economisch-administratief' (453,461-464) hebben afgerond. Ook de spreiding in de bedrijfssectoren en beroepssegmenten waarin de hoger technisch, economisch en verzorgend opgeleiden (5-6) werkzaam zijn, is verhoudingsgewijs groot. Met name bij het 'Hoger onderwijs verzorgend' $(5-6)$ is dit echter mogelijk een gevolg zijn van het samenvoegen van verschillende opleidingstypen.

Er moet echter worden opgemerkt dat de technisch opgeleiden (331-339, 436-439 en 5-6) doorgaans vaak werkzaam zijn in vrij nauw op de opleidingsrichting aansluitende beroepssegmenten. Het grote aantal beroepssegmenten waarin deze arbeidskrachten werkzaam zijn, wordt voornamelijk bepaald door de grote verscheidenheid aan richtingen binnen deze opleidingscategorieën. De economisch-administratief opgeleiden (361-369, 453,461-464 en 5-6) kunnen in een groot aantal verschillende economisch-administratieve beroepen (6) 
terechtkomen. Met betrekking tot de hoger technisch opgeleiden (5-6) moet worden opgemerkt dat meer dan $20 \%$ werkzaam is in 'Middelbare technische, ambachts- en industrieberoepen' (302), hetgeen beroepen betreft die qua functieniveau onder het niveau van de voltooide opleiding liggen. Van de werkzame personen met 'Hoger onderwijs economisch' (5-6) is een relatief groot percentage werkzaam in de beroepssegmenten 'Secretaressen, typisten' (6122) en 'Boekhoudkundige, belasting-en bankemployées' (6124). De beroepen behorend tot deze beroepssegmenten hebben een relatief laag functieniveau ten opzichte van de gevolgde opleiding.

\subsection{Leeftijdsstructuur}

De leeftijdsstructuur van de Nederlandse bevolking is sinds de jaren '60 aanzienlijk veranderd (CPB, 1992). Het aantal jongeren is sterk afgenomen, terwijl het aantal ouderen voortdurend is gestegen. De groene $d r u k^{13}$ is in de periode 1960-1990 met ruim 30\%-punten gedaald van $71 \%$ naar $42 \%$. Daarentegen is de grijze $d{ }^{2} k^{14}$ in dezelfde periode gestegen van $14 \%$ tot $21 \%$. Naar verwachting zal de grijze druk in de komende tijd nog verder toenemen. Ook voor de werkzame personen hebben de verschuivingen die er optreden in de leeftijdsstructuur van de bevolking belangrijke gevolgen. In deze paragraaf wordt een beeld geschetst van de leeftijdsstructuur van de werkzame personen in de provincie Noord-Holland.

Tabel 2.9 geeft een overzicht van de leeftijdsstructuur van de werkenden per bedrijfsklasse. Zoals mocht worden verwacht is het percentage jongeren (15 tot 24 jaar) relatief groot in de bedrijfsklassen 'Bouwnijverheid en -installatiebedrijven' (5), 'Detailhandel' (65-66) en 'Hotels, restaurants, cafés e.d.' (67). In de bedrijfsklasse 'Openbaar bestuur, defensie, wettelijke sociale verzekering' (90) is een relatief laag percentage jongeren werkzaam. Het percentage oudere arbeidskrachten, hier gedefinieerd als de werkzame personen tussen de 50 en 64 jaar, is verhoudingsgewijs hoog in de bedrijfsklasse 'Landbouw, visserij en bosbouw' (0). In deze bedrijfsklasse is de vergrijzingsproblematiek derhalve het grootst. Het percentage ouderen is verhoudingsgewijs laag bij de 'Gezondheids- en veterinaire diensten' (93). Tenslotte kan worden geconcludeerd dat in de bedrijfsklassen 'Luchtvaart' (75), 'Onderwijs' (92) en 'Sociaal-culturele en culturele instellingen' (95) veruit de meeste werkenden behoren tot de leeftijdsgroep van 25 tot 49 jaar. In de bedrijfsklassen 'Landbouw, visserij en bosbouw' (0), 'Machine-industrie' (35), 'Instrumenten-, optische en overige industrie' $(38,39)$ en 'Detailhandel' $(65-66)$ is het percentage werkenden in de leeftijdsklasse 25-49 jarigen duidelijk lager dan in andere bedrijfsklassen.

13. Dit is de bevolking van 0 tot 19 jaar uitgedrukt als percentage van de bevolking van 20 tot 64 jaar.

14. Dit is de bevolking ouder dan 65 jaar uitgedrukt als percentage van de bevolking van 20 tot 64 jaar. 
Tabel 2.9. Leeftijdsopbouw van de werkzame personen per bedrijfsklasse, gemiddelde 1989-1991

\begin{tabular}{|c|c|c|c|c|}
\hline Code & bedrijfsklasse & $\begin{array}{r}15-24 \\
\text { jaar }\end{array}$ & $\begin{array}{r}25-49 \\
\text { jaar }\end{array}$ & $\begin{array}{r}50-64 \\
\text { jaar }\end{array}$ \\
\hline 0 & Landbouw, visserij en bosbouw & $20^{\circ}$ & 53 & 24 \\
\hline 1 & Delfstoffenwinning & $\therefore$ & & . \\
\hline $20-21$ & Voedings- en genotmiddelenindustrie & $22^{*}$ & 67. & . \\
\hline $22-24$ & Kleding- en schoenenindustrie & $\cdot$ & $56^{\circ}$ & $\cdot$ \\
\hline 25,32 & Hout- en bouwmaterialenindustrie & & $75^{\circ}$ & \\
\hline 26,27 & Papier- en grafische industrie & $17^{*}$ & 69 & $13^{*}$ \\
\hline 28 & Aardolie- en steenkoolverwerking & & & \\
\hline $29-31$ & Chemie & $14^{*}$ & 72 & $17^{\circ}$ \\
\hline 33 & Basismetaalindustrie & & 72 & $19^{*}$ \\
\hline 34 & Metaalprodukten (excl. machines e.d) & $20^{*}$ & 65 & \\
\hline 35 & Machine-industrie & & 61 & $22^{\circ}$ \\
\hline 36 & Elektrotechnische industrie & $17^{*}$ & 71 & $\cdot$ \\
\hline 37 & Transportmiddelenindustrie & & 70 & . \\
\hline 38,39 & Instrumenten-, optische en overige industrie & $26^{*}$ & 58 & . \\
\hline 40 & Openbare nutsbedrijven & & 67 & \\
\hline 5 & Bouwnijverheid en -installatiebedrijven & 22 & 63 & $15^{\circ}$ \\
\hline $61-64$ & Groothandel & 19 & 68 & 14 \\
\hline $65-66$ & Detailhandel & 32 & 56 & 12 \\
\hline 67 & Hotels, restaurants, cafés e.d. & 23 & 66 & $9^{*}$ \\
\hline 68 & Reparatiebedrijven voor gebruiksgoederen & $22^{*}$ & 65 & \\
\hline 71-74 & Weg- en watervervoer & $15^{*}$ & 72 & $13^{\circ}$ \\
\hline 75 & Luchtvaart & $10^{\circ}$ & 81 & $8^{\circ}$ \\
\hline 76-77 & Hulpbedrijven van het vervoer en communicatiebedrijven & $15^{*}$ & 76 & $9^{*}$ \\
\hline 81 & Bankwezen & 13 & 77 & $9^{*}$ \\
\hline 82 & Verzekeringswezen & $17^{*}$ & 71 & . \\
\hline $83-85$ & Handel onroerend goed, zakelijke dienstverlening & & & \\
\hline & en verhuur roerende goederen & 15 & 72 & 13 \\
\hline 90 & Openbaar bestuur, defensie, wettelijke sociale verzekering & 11 & 78 & 11 \\
\hline 92 & Onderwijs & & 83 & 15 \\
\hline 93 & Gezondheids- en veterinaire diensten & 13 & 78 & 9 \\
\hline 94 & Maatschappelijke dienstverlening & 14 & 72 & 14. \\
\hline 95 & Sociaal-culturele en culturele instellingen & . & 80. & $15^{\circ}$ \\
\hline 96 & Sport en recreatie & . & $75^{\circ}$ & \\
\hline 91,97 & Religieuze en overige sociale organisaties & & 65 & $24^{\circ}$ \\
\hline \multirow[t]{2}{*}{98} & Overige dienstverlenende bedrijven & $21^{*}$ & 66 & $13^{*}$ \\
\hline & Totaal & 16 & 71 & 13 \\
\hline \multicolumn{5}{|c|}{$*=$ grote marges } \\
\hline
\end{tabular}

De werkenden in de hogere beroepen ${ }^{15}$ zijn, als gevolg van de relatief lange studieduur, in het algemeen ouder dan 24 jaar. Uit de cijfers met betrekking tot de leeftijdsstructuur per beroepssegment blijkt dat in de 'Agrarische beroepen' (2) relatief veel ouderen werkzaam zijn. Dit is overeenkomstig het grote aantal ouderen in de bedrijfsklasse 'Landbouw, visserij en bosbouw' (0). Bij de beroepssegmenten 'Middelbare technische, ambachts- en industrieberoepen' (302), 'Middelbare commerciële beroepen' (622) en 'Portiers, schoonmaak- e.a. lager dienstverlenend personeel' (8211) is eveneens een hoog percentage werkenden tussen de 50 en 64 jaar oud.

15. Dit zijn beroepen waarbij meer dan de helft van de beroepsbeoefenaren een opleiding in het WO of HBO heeft afgerond (zie Van de Loo, Dekker en De Grip, 1992). Het gaat hierbij om de ROAberoepsklassen, waarbij het derde digit gelijk is aan 3 . 
Tabel 2.10. Leeftijdsopbouw van de werkzame personen per beroepssegment, gemiddelde 1989-1991

\begin{tabular}{|c|c|c|c|c|}
\hline Code & beroepssegment & $\begin{array}{r}15-24 \\
\text { jaar }\end{array}$ & $\begin{array}{r}25-49 \\
\text { jaar }\end{array}$ & $\begin{array}{r}50-64 \\
\text { jaar }\end{array}$ \\
\hline 0 & Pedagogische beroepen & . & 83 & 15 \\
\hline 1 & Culturele beroepen & & 78 & $16^{*}$ \\
\hline 2 & Agrarische beroepen & 21 & 57 & 25 \\
\hline 301 & Lagere technische, ambachts- en industrieberoepen & & $67^{*}$ & \\
\hline 302 & Middelbare technische, ambachts- en industrieberoepen & $5^{*}$ & 74 & 22 \\
\hline 303 & Hogere technische, ambachts- en industrieberoepen & & 86 & • \\
\hline 311 & Lagere voedings- en genotmiddelenberoepen & $33^{*}$ & 56 & . \\
\hline 321 & Lagere textielberoepen & & $64^{*}$ & . \\
\hline 331 & Lagere hout- en papierberoepen & $20^{*}$ & 65 & . \\
\hline 341 & Lagere grafische beroepen & $19^{*}$ & 71 & . \\
\hline 351 & Lagere chemische beroepen & & $71^{*}$ & \\
\hline 361 & Lagere metaalberoepen & 18. & 68 & $12^{*}$ \\
\hline 362 & Middelbare metaalberoepen & $27^{*}$ & $60^{\circ}$ & . \\
\hline 363 & Hogere metaalberoepen & 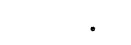 & $80^{\circ}$ & . \\
\hline 371 & Lagere elektrotechnische beroepen & & $71^{\circ}$ & . \\
\hline 372 & Middelbare elektrotechnische beroepen & $25^{*}$ & 68 & . \\
\hline 373 & Hogere elektrotechnische beroepen & . & & . \\
\hline 381 & Lagere bouwmaterialen-, glas- en aardewerkberoepen & & $57^{*}$ & \\
\hline 391 & Lagere bouw- en installatieberoepen & $23^{*}$ & 60 & $17^{*}$ \\
\hline 392 & Middelbare bouw- en installatieberoepen & . & $80^{\circ}$ & $\cdot$ \\
\hline 393 & Hogere bouw- en installatieberoepen & . & $83^{*}$ & . \\
\hline 40 & Transportberoepen & 30 & 58 & $13^{*}$ \\
\hline 41 & Maritieme e.a. waterwegtransportberoepen & & & \\
\hline 42 & Rail- en wegtransportberoepen & $10^{*}$ & 76 & $12^{\circ}$ \\
\hline 43 & Lucht- en overige transportberoepen & & 79 & . \\
\hline 5021 & Gediplomeerde verpleegkundigen, verloskundigen & $11^{*}$ & 82 & . \\
\hline 5022 & Leerling-verpleegkundigen, zieken- en kraamverzorgenden & 28: & 69 & . \\
\hline $5023-5025$ & Dokters-, tandarts-, apothekersassistenten en andere paramedici & $22^{*}$ & 67 & \\
\hline 503 & Hogere medische en paramedische beroepen & . & 85 & $10^{\circ}$ \\
\hline 603 & Hogere economisch-administratieve beroepen & . & 81 & $16^{*}$ \\
\hline 6111 & Postdistributiepersoneel & . & 75 & . \\
\hline 6112 & Datatypisten, computeroperators & . & $80^{*}$ & . \\
\hline 6121 & Leidinggevend administratief personeel & . & 79 & . \\
\hline 6122 & Secretaressen, typisten & 22 & 69 & $8^{\circ}$ \\
\hline 6123 & Bibliotheek- en archiefmedewerkers & & $71^{\circ}$ & . \\
\hline 6124 & Boekhoudkundige, belasting- en bankemployées & 19 & 69 & 12 \\
\hline 6125 & Commercieel-administratieve employées & 20 & 69 & 12 \\
\hline 6126 & Telefonisten, balie-employées, enquêteurs e.d. & $25^{*}$ & 69 & . \\
\hline 6131 & Systeemanalisten, -programmeurs en -beheerders & $\cdot$ & 90 & . \\
\hline 6132 & Economen, accountants e.a. economische specialisten & & 75 & \\
\hline 621 & Lagere commerciële beroepen & 44 & 47 & $9^{*}$ \\
\hline 622 & Middelbare commerciële beroepen & $8^{*}$ & 73 & 18 \\
\hline 633 & Hogere bestuurlijke en juridische beroepen & . & 88 & . \\
\hline 702 & Middelbare sociaal-culturele beroepen & . & 86 & \\
\hline 703 & Hogere sociaal-culturele beroepen & & 83 & $10^{*}$ \\
\hline 811 & Lagere horecaberoepen & 30 & 60 & $8^{*}$ \\
\hline 812 & Middelbare horecaberoepen & & 80 & $20^{*}$ \\
\hline 8211 & Portiers, schoonmaak- e.a. lager dienstverlenend personeel & $14^{*}$ & 68 & 18 \\
\hline 8212 & Kinder-, gezins-, bejaardenverzorgenden & $25^{*}$ & 63 & $13^{*}$ \\
\hline 822 & Middelbare verzorgende beroepen & & $60^{\circ}$ & . \\
\hline 912 & Middelbare politie-, brandweer-en bewakingsberoepen & $15^{\circ}$ & 74 & . \\
\hline \multirow[t]{2}{*}{922} & Middelbare militaire beroepen & $\cdot$ & $73^{*}$ & . \\
\hline & Totaal & 16 & 71 & 13 \\
\hline
\end{tabular}

Bron: CBS

Jongeren zijn oververtegenwoordigd in de 'Agrarische beroepen' (2). Aangenomen mag worden dat dit een gevolg van de inzet van jongeren bij sterk seizoensgebonden activiteiten. In de 
'Transportberoepen' (40) is een ook relatief hoog percentage jongeren werkzaam. In enkele economisch-administratieve beroepen (6) is het percentage jongeren relatief hoog, te weten: 'Secretaressen, typisten' (6122), 'Commercieel-administratieve employées' (6125) en 'Lagere commerciële beroepen' (621). Met betrekking tot de verzorgende en dienstverlenende beroepen (8) is het percentage jongeren relatief hoog in de 'Lagere horecaberoepen' (811). Bij de medische en paramedische beroepen (5) valt op dat meer dan $80 \%$ van de werkenden in het beroepssegment 'Gediplomeerde verpleegkundigen, verloskundigen' (5021) tussen de 25 en 49 jaar oud is. Hetzelfde geldt voor de sociaal-culturele beroepssegmenten (7) en de 'Pedagogische beroepen' (0).

Tabel 2.11. Leeftijdsopbouw van de werkzame personen per opleidingstype, gemiddelde 1990-1991

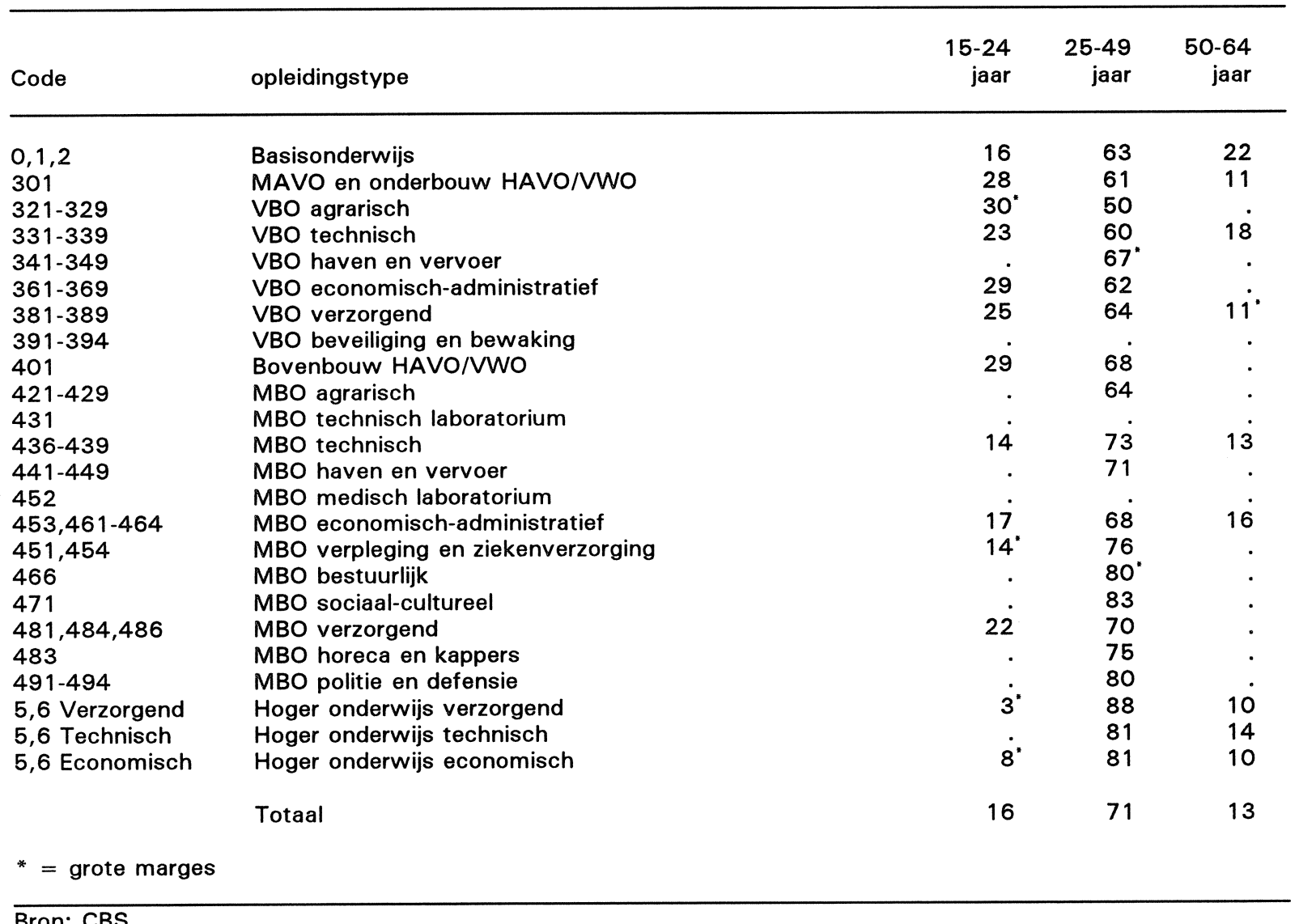

De leeftijdsopbouw per opleidingstype is sterk afhankelijk van het opleidingsniveau (zie tabel 2.11). Van de 'ongeschoolden', dat zijn de werkenden met uitsluitend basisonderwijs $(0,1,2)$, is een relatief hoog percentage tussen de 50 en 64 jaar oud. Niettemin bedraagt het percentage jongeren binnen deze opleidingscategorie nog steeds $16 \%$. Ook bij de technisch opgeleiden op VBO-niveau (331-339) en de economisch-administratief opgeleiden op MBO-niveau $(453,461-464)$ is een relatief hoog percentage 50 jaar of ouder. Daarentegen wordt een aantal andere opleidingstypen juist gekenmerkt door een relatief hoog percentage jongeren, te weten: 'MAVO en onderbouw HAVO/VWO' (301), 'VBO technisch' (331-339), 'VBO economischadministratief' (361-369), 'VBO verzorgend' (381-389), 'Bovenbouw HAVO/VWO' (401) en 
'MBO verzorgend' $(481,484,486)$. Meer dan $80 \%$ van de werkzame personen die een hogere opleiding (5-6) hebben voltooid is tussen 25 en 49 jaar oud. Een tweetal opleidingstypen op MBO-niveau wordt eveneens gekenmerkt door een verhoudingsgewijs hoog percentage werkzame personen dat tussen de 25 en 49 jaar oud is, namelijk 'MBO sociaal-cultureel' (471) en 'MBO politie en defensie' (491-494). Een relatief laag percentage van de werkenden met een opleiding 'VBO agrarisch' (321-329) en 'VBO technisch' (331-339) is tussen de 25 en 49 jaar oud.

\subsection{Vrouwen op de arbeidsmarkt}

De afgelopen decennia is het aantal vrouwen dat zich aanbiedt op de arbeidsmarkt sterk gestegen. In de periode 1960-1990 is de participatiegraad van vrouwen meer dan verdubbeld (zie Ministerie van Sociale Zaken en Werkgelegenheid, 1990). Vrouwen zijn echter veelal werkzaam in andere beroepen dan mannen (zie ook Van Mourik en Siegers, 1988 en ROA, 1992). Er is wat dit betreft sprake van een duidelijk segregatie-effect. Hierdoor kunnen typische 'vrouwenberoepen' en daaraan gerelateerde 'vrouwenopleidingen' worden onderscheiden. Daarbij wordt gesproken van vrouwenberoepen en vrouwenopleidingen indien vrouwen meer dan $60 \%$ van de werkenden uitmaken (Siegers, 1979). De arbeidsmarktpositie van vrouwen wordt in beeld gebracht door middel van het percentage werkende vrouwen in de onderscheiden bedrijfsklassen, beroepssegmenten en de opleidingstypen. Vanwege het feit dat vrouwen vaak werkzaam zijn in deeltijd banen, zal telkens tevens een indicatie worden gegeven van de mate waarin in deeltijd wordt gewerkt ${ }^{16}$.

In tabel 2.12 wordt per bedrijfsklasse het percentage werkende vrouwen en het percentage dat in deeltijd werkzaam is, gepresenteerd. Het aandeel van vrouwen in de totale werkgelegenheid in de provincie Noord-Holland bedraagt $40 \%$. De participatiegraad van vrouwen in NoordHolland ligt daarmee boven het gemiddelde voor geheel Nederland, waar vrouwen slechts $35 \%$ van het totaal aantal werkenden uitmaken (zie ROA, 1993). In de bedrijfsklassen 'Gezondheidsen veterinaire diensten' (93) en 'Maatschappelijke dienstverlening' (94) vormen de vrouwen respectievelijk $70 \%$ en $80 \%$ van het totaal aantal werkenden. Bovendien bestaat meer dan de helft van de werkenden in de bedrijfsklassen 'Onderwijs' (92), 'Sociaal-culturele en culturele instellingen' (95), 'Overige dienstverlenende bedrijven' (98) en 'Detailhandel' (65-66) uit vrouwen.

Van het totaal aantal werkende vrouwen in Noord-Holland werkt ruim 50\% tussen de 12 en 34 uur per week. In de bedrijfsklassen 'Onderwijs' (92), 'Gezondheids- en veterinaire diensten' (93) en 'Maatschappelijke dienstverlening' (94) werken relatief veel vrouwen in deeltijd. In de 'Detailhandel' (65-66) en 'Sociaal-culturele en culturele instellingen' (95) is het percentage vrouwen dat in deeltijd werkzaam is ongeveer gelijk aan het gemiddelde in de provincie.

16. Daarbij is, volgens de definitie van de werkzame personen, uitgegaan van vrouwen die minimaal 12 uur per week werken. 
Tabel 2.12. Percentage vrouwen per bedrijfsklasse en aandeel deeltijd werkenden hiervan, gemiddelde 19891991

\begin{tabular}{|c|c|c|c|c|}
\hline \multirow[b]{3}{*}{ Code } & \multirow[b]{3}{*}{ bedrijfsklasse } & \multirow[b]{3}{*}{ vrouwen } & \multicolumn{2}{|c|}{ deeltijd werk } \\
\hline & & & $12-19$ & $20-34$ \\
\hline & & & uur & uur \\
\hline 0 & Landbouw, visserij en bosbouw & 27 & . & $33^{*}$ \\
\hline 1 & Delfstoffenwinning & & • & . \\
\hline $20-21$ & Voedings- en genotmiddelenindustrie & 28. & - & - \\
\hline $22-24$ & Kleding- en schoenenindustrie & $44^{*}$ & . & . \\
\hline 25,32 & Hout- en bouwmaterialenindustrie & & $\cdot$ & $\therefore$ \\
\hline 26,27 & Papier- en grafische industrie & 37 & · & $32^{*}$ \\
\hline $\begin{array}{l}28 \\
29-31\end{array}$ & Aardolie- en steenkoolverwerking & 28 & $\cdot$ & $\cdot$ \\
\hline $29-31$ & Chemie & 28 & $\cdot$ & . \\
\hline 33 & Basismetaalindustrie & - & . & . \\
\hline 34 & Metaalprodukten (excl. machines e.d) & $\cdot$ & . & . \\
\hline 35 & Machine-industrie & & . & - \\
\hline 36 & Elektrotechnische industrie & $21^{*}$ & . & . \\
\hline 37 & Transportmiddelenindustrie & & . & . \\
\hline 38,39 & Instrumenten-, optische en overige industrie & $32^{*}$ & . & . \\
\hline 40 & Openbare nutsbedrijven & & . & . \\
\hline 5 & Bouwnijverheid en -installatiebedrijven & $13^{*}$ & & \\
\hline $61-64$ & Groothandel & 33 & $10^{\circ}$ & 28 \\
\hline $65-66$ & Detailhandel & 54 & 17 & 32 \\
\hline 67 & Hotels, restaurants, cafés e.d. & 41 & $17^{\circ}$ & $30^{\circ}$ \\
\hline 68 & Reparatiebedrijven voor gebruiksgoederen & & . & . \\
\hline $71-74$ & Weg-en watervervoer & $17^{*}$ & . & \\
\hline 75 & Luchtvaart & 29 & . & $36^{*}$ \\
\hline $76-77$ & Hulpbedrijven van het vervoer en communicatiebedrijven & 35 & . & $38^{*}$ \\
\hline 81 & Bankwezen & 40 & . & $23^{*}$ \\
\hline 82 & Verzekeringswezen & 42 & . & . \\
\hline \multirow[t]{2}{*}{$83-85$} & Handel onroerend goed, zakelijke dienstverlening & & & \\
\hline & en verhuur roerende goederen & 42 & $10^{*}$ & 31 \\
\hline 90 & Openbaar bestuur, defensie, wettelijke sociale verzekering & 30 & $11^{\circ}$ & 36 \\
\hline 92 & Onderwijs & 52 & 20 & 43 \\
\hline 93 & Gezondheids- en veterinaire diensten & 70 & 14 & 43 \\
\hline 94 & Maatschappelijke dienstverlening & 80 & 24 & 48 \\
\hline \multirow{5}{*}{$\begin{array}{l}95 \\
96 \\
91,97 \\
98\end{array}$} & Sociaal-culturele en culturele instellingen & 50 & . & 48 \\
\hline & Sport en recreatie & $42^{*}$ & . & . \\
\hline & Religieuze en overige sociale organisaties & $35^{*}$ & . & \\
\hline & Overige dienstverlenende bedrijven & 53 & $25^{*}$ & $40^{\circ}$ \\
\hline & Totaal & 40 & 15 & 36 \\
\hline$*$ & es & & & \\
\hline
\end{tabular}

Bron: CBS

Uit tabel 2.13 komt duidelijk naar voren dat vrouwen veelal in andere beroepen werkzaam zijn dan mannen. Meer dan de helft van de werkenden in de medische en paramedische (5), de sociaal-culturele (7) en de verzorgende en dienstverlenende (8) beroepen bestaat uit vrouwen. Van de vrouwen die werkzaam zijn in de beroepssegmenten 'Portiers, schoonmaak- e.a. lager dienstverlenend personeel' (8211) en 'Kinder-, gezins-, bejaardenverzorgenden' (8212) werkt een relatief groot percentage in deeltijd. Van de in de beroepen 'Gediplomeerde verpleegkundigen, zieken- en kraamverzorgenden' (5021), 'Hogere sociaal-culturele beroepen' (703) en 'Lagere horecaberoepen' (811) werkzame vrouwen is een verhoudingsgewijs groot percentage tussen 20 en 34 uur per week werkzaam. 
Tabel 2.13. Percentage vrouwen per beroepssegment en aandeel deeltijd werkenden hiervan, gemiddelde 1989 1991

\begin{tabular}{|c|c|c|c|c|}
\hline \multirow[b]{2}{*}{ Code } & \multirow[b]{2}{*}{ beroepssegment } & \multirow[b]{2}{*}{ vrouwen } & \multicolumn{2}{|c|}{ deeltijd werk } \\
\hline & & & uur & uur \\
\hline 0 & Pedagogische beroepen & 49 & $18^{*}$ & 43 \\
\hline 1 & Culturele beroepen & 47 & . & 33" \\
\hline 2 & $\begin{array}{l}\text { Agrarische beroepen } \\
\text { agere technische ambachts- en industrieberoepen }\end{array}$ & 23 & . & $33^{*}$ \\
\hline 301 & Lagere technische, ambachts- en industrieberoepen & & . & . \\
\hline 302 & Middelbare technische, ambachts- en industrieberoepen & 11 & . & - \\
\hline 303 & Hogere technische, ambachts- en industrieberoepen & $\cdot$ & - & - \\
\hline 311 & Lagere voedings- en genotmiddelenberoepen & $45^{*}$ & $\cdot$ & - \\
\hline 321 & Lagere textielberoepen & 45 & - & $\cdot$ \\
\hline 331 & Lagere hout- en papierberoepen & & - & - \\
\hline 341 & Lagere grafische beroepen & $24^{*}$ & $\cdot$ & $\cdot$ \\
\hline 351 & Lagere chemische beroepen & . & - & - \\
\hline 361 & Lagere metaalberoepen & - & - & · \\
\hline 362 & Middelbare metaalberoepen & - & - & - \\
\hline 363 & Hogere metaalberoepen & . & - & - \\
\hline 371 & Lagere elektrotechnische beroepen & - & - & - \\
\hline 372 & Middelbare elektrotechnische beroepen & . & - & $\cdot$ \\
\hline 373 & Hogere elektrotechnische beroepen & - & . & - \\
\hline 381 & Lagere bouwmaterialen-, glas- en aardewerkberoepen & $\cdot$ & $\cdot$ & $\cdot$ \\
\hline 391 & Lagere bouw-en installatieberoepen & . & - & $\cdot$ \\
\hline 392 & Middelbare bouw- en installatieberoepen & $\cdot$ & $\cdot$ & · \\
\hline 393 & Hogere bouw-en installatieberoepen & $0^{\circ}$ & - & $\cdot$ \\
\hline 40 & Transportberoepen & 20 & . & - \\
\hline 41 & Maritieme e.a. waterwegtransportberoepen & . & • & · \\
\hline 42 & Rail- en wegtransportberoepen & . & $\cdot$ & - \\
\hline 43 & Lucht- en overige transportberoepen & $\dot{8}$ & $\therefore$ & . \\
\hline 5021 & Gediplomeerde verpleegkundigen, verloskundigen & 80 & $14^{\circ}$ & 46 \\
\hline 5022 & Leerling-verpleegkundigen, zieken- en kraamverzorgenden & 86 & $16^{*}$ & $32^{\circ}$ \\
\hline $5023-5025$ & Dokters-, tandarts-, apothekersassistenten en andere paramedici & 89 & . & $44^{\circ}$ \\
\hline 503 & Hogere medische en paramedische beroepen & 53 & . & $43^{\circ}$ \\
\hline 603 & Hogere economisch-administratieve beroepen & $26^{*}$ & . & . \\
\hline 6111 & Postdistributiepersoneel & $25^{*}$ & . & . \\
\hline 6112 & Datatypisten, computeroperators & & . & - \\
\hline 6121 & Leidinggevend administratief personeel & $36^{*}$ & & $\therefore$ \\
\hline 6122 & Secretaressen, typisten & 98 & $7^{*}$ & 31 \\
\hline 6123 & Bibliotheek- en archiefmedewerkers & $71^{*}$ & . & . \\
\hline 6124 & Boekhoudkundige, belasting- en bankemployées & 51 & 14. & 30 \\
\hline 6125 & Commercieel-administratieve employées & 52 & $10^{*}$ & 32 \\
\hline 6126 & Telefonisten, balie-employées, enquêteurs e.d. & 78 & $16^{*}$ & 40 \\
\hline 6131 & Systeemanalisten, -programmeurs en -beheerders & $13^{*}$ & . & . \\
\hline 6132 & Economen, accountants e.a. economische specialisten & $25^{*}$ & & \\
\hline 621 & Lagere commerciële beroepen & 63 & $18^{*}$ & 35 \\
\hline 622 & Middelbare commerciële beroepen & 25 & . & . \\
\hline 633 & Hogere bestuurlijke en juridische beroepen & $29^{*}$ & . & . \\
\hline 702 & Middelbare sociaal-culturele beroepen & $50^{*}$ & . & \\
\hline 703 & Hogere sociaal-culturele beroepen & 56 & . & 48 \\
\hline 811 & Lagere horecaberoepen & 52 & $23^{*}$ & 42 \\
\hline 812 & Middelbare horecaberoepen & $40^{\circ}$ & & \\
\hline 8211 & Portiers, schoonmaak- e.a. lager dienstverlenend personeel & 59 & 33 & 36 \\
\hline 8212 & Kinder-, gezins-, bejaardenverzorgenden & 97 & 32 & 45 \\
\hline 822 & Middelbare verzorgende beroepen & $80^{\circ}$ & . & $50^{\circ}$ \\
\hline 912 & Middelbare politie-, brandweer- en bewakingsberoepen & . & . & . \\
\hline \multirow[t]{2}{*}{922} & Middelbare militaire beroepen & $\cdot$ & $\cdot$ & $\cdot$ \\
\hline & Totaal & 40 & 15 & 36 \\
\hline
\end{tabular}


Binnen de economisch-administratieve beroepen zijn er duidelijk verschillen waar te nemen in het aandeel van vrouwen in het totaal aantal werkenden. In de beroepssegmenten 'Secretaressen, typisten' (6122), 'Boekhoudkundige, belasting- en bankemployées' (6124), 'Commercieel-administratieve employées' (6125), 'Telefonisten, balie-employées, enquêteurs e.d.' (6126) en 'Lagere commerciële beroepen' (621) zijn verhoudingsgewijs veel vrouwen werkzaam. Een relatief groot percentage vrouwen dat werkzaam is in het beroepssegment 'Telefonisten, balie-employées, enquêteurs e.d.' (6126) heeft een werkweek van 20 tot 35 uur. Daarentegen is het aantal vrouwen in de 'Middelbare commerciële beroepen' (622) relatief laag. Het aandeel van vrouwen in de 'Pedagogische beroepen' en de 'Culturele beroepen' bedraagt ongeveer $50 \%$. Daarbij heeft een relatief groot percentage vrouwen dat werkzaam is in de 'Pedagogische beroepen' (0) een baan met een werkweek tussen 20 en 34 uur. In de technische (3), transport- (4) en openbare orde- en veiligheidsberoepen (9) zijn relatief weinig vrouwen werkzaam.

Tabel 2.14. Percentage vrouwen per opleidingstype en aandeel deeltijd werkenden hiervan, gemiddelde 19901991

\begin{tabular}{|c|c|c|c|c|}
\hline Code & opleidingstype & vrouwen & $\begin{array}{c}\text { deelt } \\
12-19 \\
\text { uur }\end{array}$ & $\begin{array}{l}\text { werk } \\
20-34 \\
\text { uur }\end{array}$ \\
\hline $0,1,2$ & Basisonderwijs & 33 & 24 & 41 \\
\hline 301 & MAVO en onderbouw HAVO/VWO & 52 & 15 & 33 \\
\hline $321-329$ & VBO agrarisch & & . & . \\
\hline $331-339$ & VBO technisch & $7^{*}$ & . & . \\
\hline $341-349$ & VBO haven en vervoer & & . & \\
\hline $361-369$ & VBO economisch-administratief & 62 & & $31^{\circ}$ \\
\hline $381-389$ & VBO verzorgend & 86 & 21 & 42 \\
\hline $391-394$ & VBO beveiliging en bewaking & & & \\
\hline 401 & Bovenbouw HAVO/VWO & 45 & $12^{*}$ & 28 \\
\hline $421-429$ & MBO agrarisch & - & . & . \\
\hline 431 & MBO technisch laboratorium & 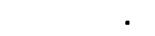 & . & . \\
\hline $436-439$ & MBO technisch & 7 & . & . \\
\hline $441-449$ & MBO haven en vervoer & & . & . \\
\hline 452 & MBO medisch laboratorium & $100^{*}$ & & \\
\hline $453,461-464$ & MBO economisch-administratief & 47 & 14 & 29 \\
\hline 451,454 & MBO verpleging en ziekenverzorging & 86 & 20 & 40 \\
\hline 466 & MBO bestuurlijk & & $\cdot$ & $\cdot$ \\
\hline 471 & MBO sociaal-cultureel & $67^{*}$ & & \\
\hline $481,484,486$ & MBO verzorgend & 81 & $14^{*}$ & 41 \\
\hline 483 & MBO horeca en kappers & $50^{\circ}$ & - & - \\
\hline $491-494$ & MBO politie en defensie & & 0 & \\
\hline \multirow{3}{*}{$\begin{array}{l}\text { 5,6 Verzorgend } \\
5,6 \text { Technisch } \\
5,6 \text { Economisch }\end{array}$} & Hoger onderwijs verzorgend & 57. & 12 & 44 \\
\hline & $\begin{array}{l}\text { Hoger onderwijs technisch } \\
\text { Hoger onderwijs economisch }\end{array}$ & $\begin{array}{l}11^{*} \\
38\end{array}$ & $\dot{.}$ & $22^{\circ}$ \\
\hline & Totaal & 40 & 15 & 36 \\
\hline${ }^{*}=$ grote marg & & & & \\
\hline
\end{tabular}

Bron: CBS

Tabel 2.14 geeft een overzicht het percentage vrouwen per opleidingstype. De tabel laat zien dat het bestaan van typische vrouwenberoepen voor een belangrijk deel reeds wordt veroorzaakt door de opleidingskeuze van vrouwen. Het zijn voornamelijk de medische $(451,454)$ en verzorgende $(381-389,481,484,486$ en 5-6) opleidingstypen waarbij meer dan de helft van 
het totaal aantal werkenden met deze opleidingsachtergrond uit vrouwen bestaat. Daarnaast is het aandeel van vrouwen in het totaal aantal werkenden met een economisch-administratieve opleidingsachtergrond op VBO-niveau (361-369) en een 'MAVO en onderbouw HAVO/VWO' (301) opleiding relatief groot.

Een tweetal opleidingstypen valt op door het relatief hoge percentage vrouwen dat in deeltijd werkt. Het gaat daarbij om de opleidingstypen 'VBO verzorgend' (381-389) en 'MBO verpleging en ziekenverzorging' $(451,454)$. Ook de ongeschoolde vrouwen $(0,1,2)$ werken relatief vaak in deeltijd. Overigens nemen vrouwen, terwijl ze gemiddeld $40 \%$ van de werkzame personen in de provincie Noord-Holland uitmaken, slechts één derde van de totale ongeschoolde arbeid voor hun rekening.

\subsection{Conclusie}

In dit hoofdstuk is de huidige werkgelegenheidsstructuur nader in beeld gebracht. Daarbij is eerst achtereenvolgens de sector-, beroepen- en opleidingenstructuur van de werkgelegenheid in beeld gebracht, waarbij telkens ook is nagegaan in hoeverre er op bepaalde punten sprake is van duidelijke verschillen tussen de vier RBA-gebieden binnen de provincie Noord-Holland. Tenslotte is de leeftijdsstructuur van de werkgelegenheid en de arbeidsmarktpositie van vrouwen nader belicht.

Het grootste werkgelegenheidsaandeel komt voor rekening van de bedrijfsklassen 'Openbaar bestuur, defensie, wettelijke sociale verzekering' (90) en 'Gezondheids- en veterinaire diensten' (93). Verder zijn in de bedrijfsklassen 'Groothandel' (61-64), 'Detailhandel' (65-66) en 'Handel onroerend goed, zakelijke dienstverlening en verhuur roerende goederen' (83-85) belangrijk voor de werkgelegenheid in de provincie Noord-Holland. In de industriële bedrijfsklassen (2-3) werkt in totaal ongeveer $15 \%$ van de arbeidskrachten. Ruim één vijfde van het totaal aantal werkenden in Noord-Holland werkt in de technische beroepen (3), terwijl in de economischadministratieve beroepen (6) $37 \%$ van de werkenden werkzaam is. Met betrekking tot de opleidingsachtergrond kan worden opgemerkt dat de werkzame personen in Noord-Holland relatief hoog geschoold (5-6) is. Met name werkenden met het heterogene opleidingstype 'Hoger onderwijs verzorgend' (5-6) zijn sterk vertegenwoordigd in de provincie. Hetzelfde geldt voor het opleidingstype 'Bovenbouw HAVO/VWO' (401). Daarentegen hebben verhoudingsgewijs weinig werkenden een technische opleiding op VBO-niveau (331-339) of MBO-niveau (436-439) voltooid.

De belangrijkste verschillen in de werkgelegenheidsstructuur tussen de vier RBA-gebieden binnen de provincie Noord-Holland worden in belangrijke mate veroorzaakt door bepaalde regionale kernactiviteiten. Te denken valt hierbij bijvoorbeeld aan de aanwezigheid van de publieke omroepen in GV, de tuinbouw en de Marinevestiging in NHN, twee academische ziekenhuizen en de hoofdkantoren van enkele grote banken in AZW en de luchthaven Schiphol en het Hoogovenconcern in KAM. 
Het percentage jongeren is relatief groot in de bedrijfsklassen 'Bouwnijverheid en -installatiebedrijven' (5), 'Detailhandel' (65-66) en 'Hotels, restaurants, cafés e.d.' (67). Daarnaast zijn jongeren zijn sterk vertegenwoordigd in de 'Agrarische beroepen' (2), 'Transportberoepen' (40), enkele economisch-administratieve beroepen (6) en de 'Lagere horecaberoepen' (811). Het percentage oudere arbeidskrachten is verhoudingsgewijs hoog in de bedrijfsklasse 'Landbouw, visserij en bosbouw' (0) en daarmee samenhangend ook in de 'Agrarische beroepen' (2). Bovendien zijn er verhoudingsgewijs veel ouderen werkzaam in de 'Middelbare technische, ambachts- en industrieberoepen' (302), 'Middelbare commerciële beroepen' (622) en 'Portiers, schoonmaak- e.a. lager dienstverlenend personeel' (8211). De werkenden in de hogere beroepen zijn, zoals mag worden verwacht, in het algemeen ouder dan 24 jaar. Het percentage jongeren onder de werkenden met een algemene (301 en 401) en VBOopleiding (3) is relatief hoog.

Ten opzichte van geheel Nederland is de participatiegraad van vrouwen in Noord-Holland relatief hoog. Van de totale werkgelegenheid in de bedrijfsklassen 'Gezondheids- en veterinaire diensten' (93) en 'Maatschappelijke dienstverlening' (94) wordt een zeer groot gedeelte ingenomen door vrouwen. Een groot gedeelte van deze vrouwen heeft een deeltijd baan. Ook zijn vrouwen veelal in andere beroepen werkzaam dan mannen. Zo vormen vrouwen meer dan de helft van de werkenden in de medische en paramedische (5), de sociaal-culturele (7) en de verzorgende en dienstverlenende (8) beroepen. Daarentegen zijn er in de technische (3), transport- (4) en openbare orde en veiligheidsberoepen (9) relatief weinig vrouwen werkzaam. Het bestaan van typische vrouwenberoepen wordt in belangrijke mate veroorzaakt door de opleidingskeuze van vrouwen. Het zijn voornamelijk de medische $(451,454)$ en verzorgende (381-389, 481,484,486 en 5-6) opleidingstypen waarbij meer dan de helft van het totaal aantal werkenden met deze opleidingsachtergrond uit vrouwen bestaat. Daarbij werken voornamelijk vrouwen met 'VBO verzorgend' (381-389) en 'MBO verpleging en ziekenverzorging' $(451,454)$ vaker in deeltijd.

Voor wat betreft de mogelijkheden om op basis van de EBB de regionale werkgelegenheidsstructuur in kaart te brengen, kan worden geconcludeerd dat op provinciaal niveau vrij veel gegevens verbijzonderd naar bedrijfsklasse, beroepssegment en opleidingstype kunnen worden weergegeven. Op RBA-niveau is het aantal bedrijfsklassen, beroepssegmenten en opleidingstypen waarvoor regionale arbeidsmarktinformatie kan worden gepresenteerd kleiner. Met name voor GV is slechts in beperkte mate betrouwbare arbeidsmarktinformatie beschikbaar. Naast de verbijzondering naar RBA-gebied heeft ook de onderverdeling naar leeftijd, geslacht en wekelijkse arbeidsduur gevolgen voor de hoeveelheid informatie die kan worden gepresenteerd. Ook de tabellen waarbij informatie over branche, beroepen en opleidingen wordt gecombineerd, blijken slechts in zeer beperkte mate informatie te kunnen geven. Daarbij moet worden bedacht dat verbijzondering er niet alleen toe leidt dat er voor meer 'cellen' van een dergelijke matrix geen informatie kan worden gepresenteerd, maar ook het aantal werkenden voor de cellen waarover wel gepubliceerd kan worden, kleiner wordt. Zoals is aangegeven in hoofdstuk 1, verkleint een verregaande verbijzondering de betrouwbaarheid van de gegevens. Doordat gebruik is gemaakt van twee- of driejaarsgemiddelden speelt dit laatste probleem weliswaar wat 
$-29-$

minder, maar desalniettemin zijn de marges bij aantallen werkenden van $5.000-10.000$ toch nog relatief groot. Om de hoeveelheid te presenteren gegevens en de betrouwbaarheid er van te laten toenemen, is het wenselijk om in het vervolg bij de verbijzondering naar RBA-gebied, leeftijd, geslacht en wekelijkse arbeidsduur uit te gaan van een hoger aggregatieniveau van branches, beroepen en opleidingen. 


\section{FORENSENSTROMEN}

\subsection{Inleiding}

Forensenstromen geven een beeld van de verhouding tussen vraag en aanbod op de regionale arbeidsmarkt. Bij een grote forensenstroom kan er sprake zijn van grote verschillen tussen de vraag naar en het aanbod van werk in de desbetreffende regio. Indien bepaalde regio's betere werkgelegenheidsperspectieven bieden, zal dit een aanzuigende werking hebben op de werkzoekenden in de aangrenzende regio's. Daarentegen duidt een kleine forensenstroom op een goede aansluiting tussen de vraag naar arbeidskrachten en het aanbod van in de regio woonachtige beroepsbeoefenaren. Overigens weerspiegelen regionale pendelstromen vanzelfsprekend ook de al dan niet geplande scheiding tussen woon- en werkregio's.

De beroepen- en opleidingenstructuur van de in de regio woonachtige werkzame personen kan echter ook invloed hebben op de aantrekkelijkheid van de regio als vestigingsplaats voor bedrijven en instellingen. Wanneer wordt beoogd de werkgelegenheid voor de in de regio woonachtige beroepsbevolking te vergroten, is het echter niet voldoende alleen naar de structuur van de regionale werkgelegenheid te kijken, maar moet tevens worden nagegaan welke vraag op de arbeidsmarkt in belangrijke mate wordt vervuld door pendelaars uit andere regio's.

In dit hoofdstuk wordt nader ingegaan op de regionale mobiliteit in de provincie Noord-Holland. Voordat de sector-, beroepen- en opleidingenstructuur van de pendelstromen worden gepresenteerd, zullen eerst enkele algemene kenmerken van de forensenstromen worden belicht. Daarbij wordt een beeld geschetst van de totale omvang van de forensenstromen tussen de provincie Noord-Holland en de rest van Nederland, de regionale mobiliteit tussen de vier RBA-gebieden en de pendelstromen per leeftijdscategorie en per geslacht. In de slotparagraaf zullen de belangrijkste conclusies worden opgesomd.

Tabel 3.1. Aantal werkenden naar woonregio en werkregio, gemiddelde 1989-1991

\begin{tabular}{lrrr}
\hline Werkregio & Noord-Holland & woonregio & rest Nederland \\
\hline Noord-Holland & 756.000 & 94.000 & 850.000 \\
Rest Nederland & 41.500 & 4.768 .500 & 4.810 .000 \\
Totaal & 797.000 & 4.862 .000 & 5.660 .000 \\
\hline
\end{tabular}

Bron: CBS

In tabel 3.1. wordt een overzicht gegeven van de totale omvang van de forensenstromen tussen de provincie Noord-Holland en de rest van Nederland. Het in- en uitgaande pendelverkeer in Noord-Holland bedraagt in totaal 135.500 personen: 94.000 werkenden in de provincie NoordHolland wonen in een andere provincie, terwijl 41.500 mensen die in de provincie wonen elders werkzaam zijn. Per saldo is er derhalve sprake van een netto ingaande pendel voor de provincie 
Noord-Holland van 52.500 personen.

In tabel 3.2 wordt een beeld geschetst van de omvang van de forensenstromen tussen de vier RBA-gebieden in Noord-Holland. Bovendien geeft de tabel een beeld van de in de provincie werkzame personen die niet in Noord-Holland woonachtig zijn ${ }^{17}$. Van de in GV werkende personen is bijna één kwart woonachtig buiten de provincie; $70 \%$ van degenen die in deze regio werken, woont binnen dit RBA-gebied. Veruit de meeste arbeidskrachten die werkzaam zijn in NHN, zijn ook in dit RBA-gebied woonachtig (94\%). Van degenen die werkzaam zijn in AZW woont respectievelijk $5 \%$ en $9 \%$ in NHN en KAM. Van de werkzame personen in KAM is een groot aantal woonachtig in de RBA-gebieden NHN en AZW. Overigens wonen veel van de personen die in AZW of KAM werkzaam zijn buiten de provincie, respectievelijk $11 \%$ en $12 \%$. Ten aanzien van de mobiliteitsstromen binnen de provincie kan worden geconcludeerd, dat er bij de uitgaande pendel van NHN duidelijk sprake is van eenrichtingverkeer in de richting van beide aangrenzende RBA-gebieden. Daarentegen zijn er met name tussen de RBA-gebieden KAM en $A Z W$ omvangrijke forensenstromen in beide richtingen.

Tabel 3.2. Aantal werkenden naar woon-RBA en werk-RBA, gemiddelde 1989-1991

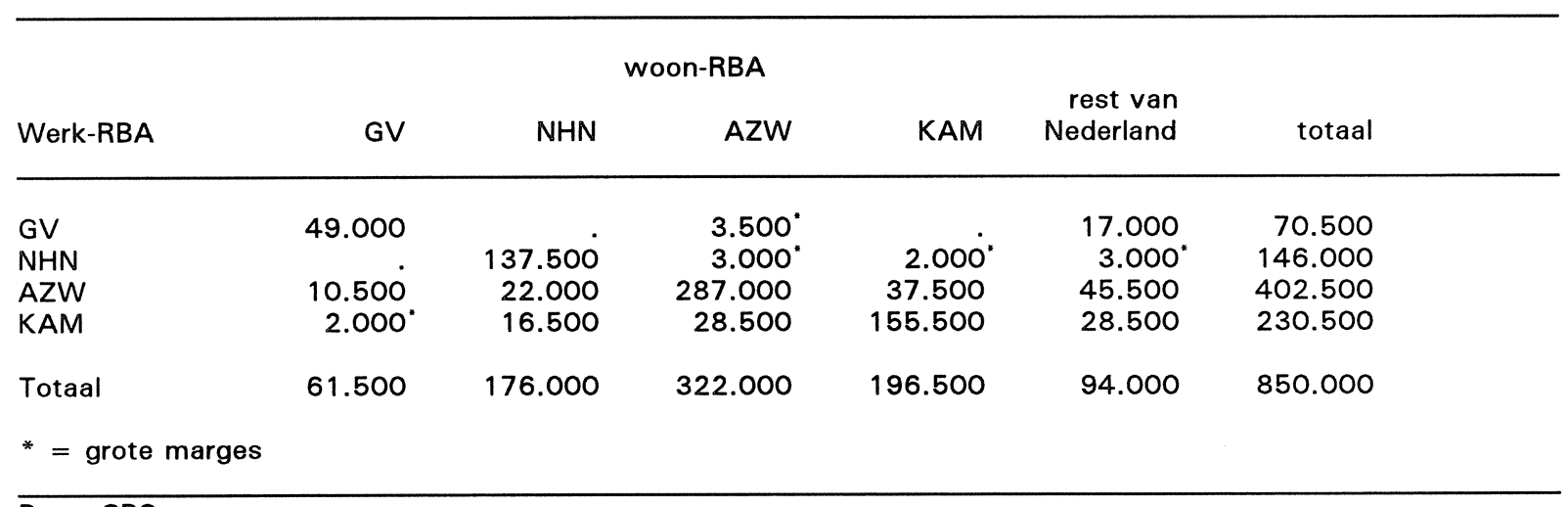

Bron: CBS

Voordat op de forensenstromen per bedrijfssector, beroepssegment en opleidingstype zal worden ingegaan, wordt eerst een algemeen beeld gegeven van de forensenstromen verbijzonderd naar leeftijd en geslacht. Daarbij wordt zowel de pendel binnen de provincie Noord-Holland in beeld gebracht, als de inkomende forensenstromen van buiten de provincie en de uitgaande pendel naar de overige regio's in Nederland. De pendel binnen de provincie heeft daarbij betrekking op degenen die werkzaam zijn in een ander RBA-gebied dan waar men woonachtig is. Zowel de ingaande als de uitgaande pendel is telkens gerelateerd aan de in Noord-Holland werkzame personen ${ }^{18}$. Dit maakt het mogelijk de netto (inkomende) pendel te bepalen door het percentage uitgaande pendel van het percentage inkomende pendel af te trekken.

17. Doordat alleen de in Noord-Holland werkzame personen in deze analyse zijn betrokken, kan niet worden aangegeven hoeveel mensen die in één van de vier RBA-gebieden binnen de provincie Noord-Holland woonachtig zijn, buiten de provincie werken.

18. Hierbij moet worden opgemerkt dat het voor de hand ligt om de uitgaande pendel te relateren aan de in de provincie Noord-Holland woonachtige werkzame personen (zie Hoevenberg, Willems en De Grip, 1993). Daar deze gegevens niet beschikbaar zijn, is dit hier niet mogelijk. 
Tabel 3.3. In- en uitgaande forensenstromen naar leeftijd, gemiddelde 1989-1991

\begin{tabular}{lrrrr}
\hline & \multicolumn{2}{c}{ inkomende } & \multicolumn{2}{c}{ uitgaande } \\
Leeftijd & aantal & $\begin{array}{r}\text { pendel } \\
\%\end{array}$ & aantal & $\%$ \\
\hline $15-24$ jaar & & & & 16 \\
$25-49$ jaar & 30.500 & 22 & 22.000 & 21 \\
$50-64$ jaar & 165.000 & 27 & 126.000 & 19 \\
Totaal & 26.000 & 24 & 21.000 & 20 \\
\hline
\end{tabular}

Bron: CBS

Tabel 3.3 schetst een beeld van forensenstromen per leeftijdscategorie. Daarbij zijn de forensenstromen tussen de vier RBA-gebieden niet meer expliciet in beeld gebracht. Uit de tabel blijkt dat maar liefst $26 \%$ van de werkenden in een van de RBA-gebieden binnen de provincie Noord-Holland niet in datzelfde RBA-gebied woonachtig is. Daarentegen is $20 \%$ van de werkenden die in één van de vier RBA-gebieden in Noord-Holland wonen, elders werkzaam. Per saldo is er derhalve sprake van een netto inkomende pendel voor de provincie Noord-Holland van $6 \%$.

Tabel 3.3 laat ook zien dat de ingaande en uitgaande forensenstromen voor jongeren en ouderen respectievelijk 5\%-punten tot 3\%-punten lager zijn dan het RBA-grensoverschrijdend woon-werkverkeer van werkenden van 25 tot 49 jaar oud. Van deze laatste groep woont $27 \%$ in een andere regio dan het RBA-gebied waar men werkzaam is, terwijl $21 \%$ van degenen die in één van de RBA-gebieden in Noord-Holland wonen, elders werkzaam is. Al met al behoort drie kwart van de pendelaars tot deze leeftijdscategorie.

Tabel 3.4. In- en uitgaande forensenstromen naar geslacht, gemiddelde 1989-1991

\begin{tabular}{lrrrr}
\hline & \multicolumn{2}{c}{$\begin{array}{c}\text { inkomende } \\
\text { pendel }\end{array}$} & \multicolumn{2}{c}{$\begin{array}{c}\text { uitgaande } \\
\text { pendel }\end{array}$} \\
Geslacht & aantal & $\%$ & aantal & $\%$ \\
\hline Mannen & 152.500 & 30 & 115.500 & 23 \\
Vrouwen & 69.000 & 20 & 53.500 & 16 \\
Totaal & 221.500 & 26 & 169.000 & 20 \\
\hline
\end{tabular}

Bron: CBS

Uit tabel 3.4 blijkt dat vrouwen minder vaak pendelen dan mannen. Zo is $30 \%$ van de mannen woonachtig buiten de regio waar men werkzaam is, tegenover $20 \%$ van de vrouwen. Daarbij bedraagt voor de provincie Noord-Holland de netto inkomende pendel van mannen en vrouwen respectievelijk $7 \%$ en $4 \%$. Al met al zijn mannen goed voor bijna $70 \%$ van de totale pendel. 


\subsection{Forensenstromen per bedrijfssector}

In tabel 3.5 worden de forensenstromen verbijzonderd naar bedrijfssector. Bij de bedrijfssector 'Vervoer en communicatie' (71-77) is zowel de ingaande als de uitgaande pendel relatief hoog. Bij deze sector is echter ook het verschil tussen de inkomende en uitgaande pendel het grootst. In deze sector is $37 \%$ van de werkenden woonachtig buiten de regio waar men werkt en bedraagt de netto inkomende pendel $15 \%$. Aangenomen mag worden dat de aanwezigheid van de luchthaven Schiphol hierbij een belangrijke rol speelt. Ook bij de 'Metaal-, elektrotechnische en transportmiddelenindustrie' (33-39) is er sprake van een relatief grote netto inkomende pendel. De inkomende pendel in deze sector heeft betrekking op $33 \%$ van de werkenden, terwijl de uitgaande pendel $24 \%$ bedraagt. Zoals in hoofdstuk 2 is aangegeven, is deze sector relatief sterk vertegenwoordigd binnen de industriële sectoren in de provincie Noord-Holland. De bedrijfssector 'Andere tertiaire diensten' $(67,68,81,82,84,85,98,99)$ wordt eveneens gekenmerkt door grote inkomende en uitgaande pendelstromen. Daarbij is er ook sprake van een relatief grote netto inkomende pendel. Deze bedrijfssector is, zoals gezegd, relatief sterk vertegenwoordigd in AZW. Bovendien vertoont deze sector verreweg de grootste pendelstromen in absolute zin. Met een inkomende en uitgaande pendel van respectievelijk 47.000 en 36.500 personen is deze sector goed voor ruim één vijfde van de totale forensenstromen.

Tabel 3.5. In- en uitgaande forensenstromen per bedrijfssector, gemiddelde 1989-1991

\begin{tabular}{|c|c|c|c|c|c|}
\hline \multirow[b]{2}{*}{ Code } & \multirow[b]{2}{*}{ bedrijfssector } & \multicolumn{2}{|c|}{$\begin{array}{l}\text { inkomende } \\
\text { pendel }\end{array}$} & \multicolumn{2}{|c|}{$\begin{array}{l}\text { uitgaande } \\
\text { pendel }\end{array}$} \\
\hline & & aantal & $\%$ & aantal & $\%$ \\
\hline \multirow{15}{*}{$\begin{array}{l}01-03 \\
20-21 \\
22-24 \\
25-27,32 \\
29-31 \\
33-39 \\
11-19,28,40 \\
51,52,83 \\
61-66 \\
71-77 \\
67,68,81,82 \\
84,85,98,99 \\
91,94-97,929 \\
93 \\
90,92, \text { excl } 929\end{array}$} & Landbouw, visserij en bosbouw & 2.000 & $9^{*}$ & . & . \\
\hline & Voedings- en genotmiddelenindustrie & 4.000 & $22^{*}$ & 3.500 & $19^{\circ}$ \\
\hline & Kleding-en schoenenindustrie & . & . & . & - \\
\hline & Overige industrie & 8.500 & 28 & 7.000 & 23 \\
\hline & Chemie & 4.500 & $31^{*}$ & 3.500 & $24^{\circ}$ \\
\hline & Metaal-, elektrotechnische, transportmiddelenindustrie & 22.000 & 33 & 16.000 & 24 \\
\hline & Delfstoffen en rest nijverheid & 2.000 & $20^{*}$ & . & . \\
\hline & Bouw en woningbezit & 7.500 & 22 & 5.500 & 16 \\
\hline & Handel & 32.500 & 25 & 24.500 & 19 \\
\hline & Vervoer en communicatie & 27.500 & 37 & 16.500 & 22 \\
\hline & & & & & \\
\hline & Andere tertiaire diensten & 47.000 & 29 & 36.500 & 22 \\
\hline & Andere kwartaire diensten & 15.000 & 19 & 12.000 & 15 \\
\hline & Gezondheids- en veterinaire diensten & 16.500 & 22 & 14.500 & 19 \\
\hline & $\begin{array}{l}\text { Openbaar bestuur, defensie, } \\
\text { wettelijke sociale verzekering en onderwijs }\end{array}$ & 30.500 & 24 & 26.000 & 21 \\
\hline & Totaal waargenomen & $219.500^{a}$ & & $165.500^{b}$ & \\
\hline & Totaal & 221.500 & 26 & 169.000 & 20 \\
\hline $\begin{array}{l}a=99 \% \text { van de } \\
b=98 \% \text { van de }\end{array}$ & $\begin{array}{l}\text { ale inkomende pendel } \\
\text { ale uitgaande persdel }\end{array}$ & & & & \\
\hline$*=$ grote marg & & & & & \\
\hline
\end{tabular}

Bron: CBS 


\subsection{Forensenstromen per beroepssegment}

Tabel 3.6. In- en uitgaande forensenstromen per beroepssegment, gemiddelde 1989-1991

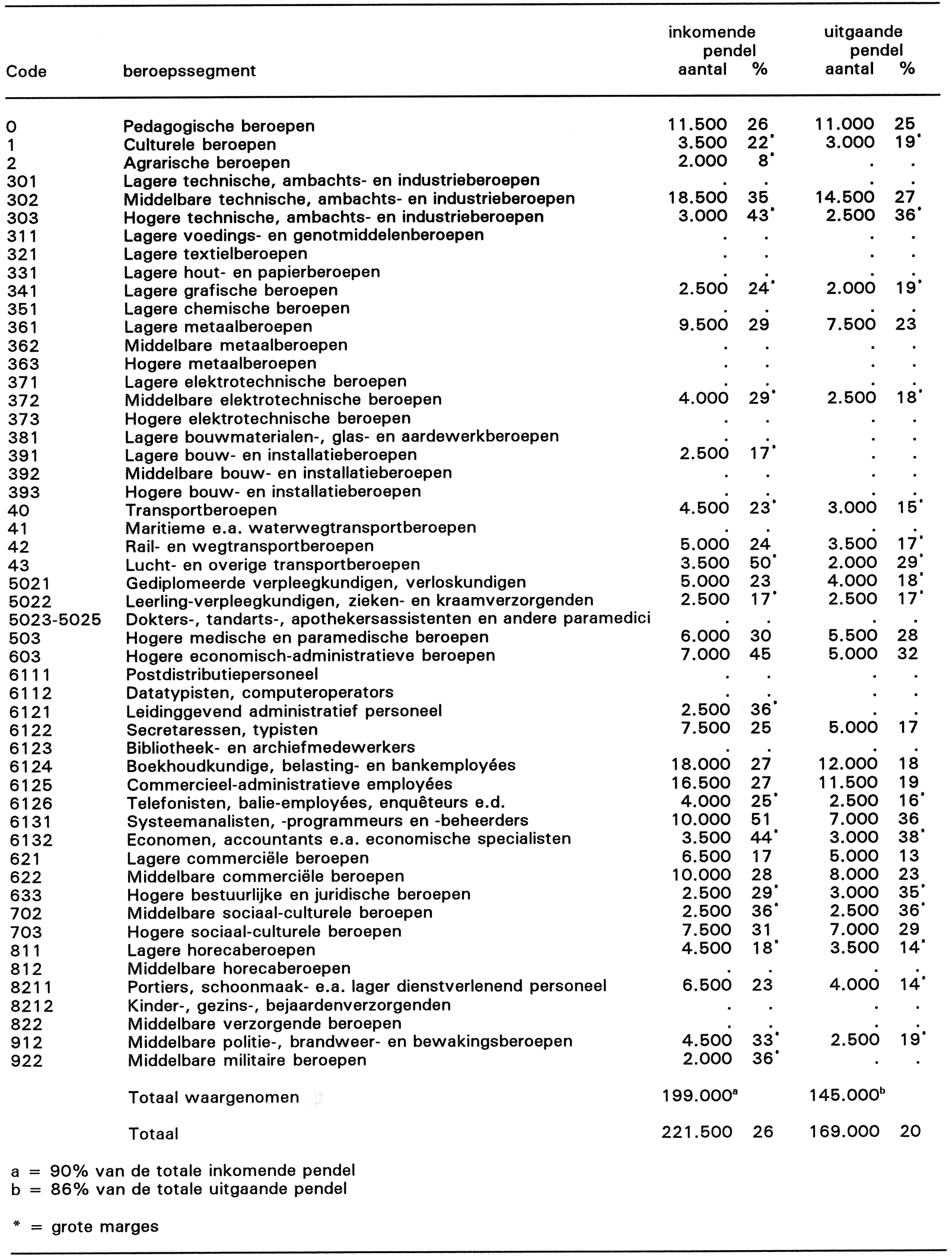


In tabel 3.6 wordt een overzicht gegeven van de forensenstromen per beroepssegment. Bij de economisch-administratieve beroepen (6) is het RBA-grensoverschrijdend woon-werkverkeer het grootst. Deze beroepen zijn goed voor circa $40 \%$ van de totale inkomende pendel, terwijl ongeveer $35 \%$ van de uitgaande pendel op deze beroepen betrekking heeft. Bij een aantal beroepssegmenten in de economisch-administratieve beroepen (6) is het verschil tussen de inkomende en uitgaande forensenstromen relatief groot. Dit is vooral het geval bij de 'Hogere economisch-administratieve beroepen' (603) en het relatief nieuwe beroepssegment 'Systeemanalisten, -programmeurs en -beheerders' (6131). In dit laatste beroepssegment woont meer dan de helft in een andere regio dan waar men werkzaam is. Daarnaast is de netto inkomende pendel verhoudingsgewijs hoog voor de beroepssegmenten 'Secretaressen, typisten' (6122), 'Boekhoudkundige, belasting- en bankemployées' (6124), 'Commercieel-administratieve employées' (6125) en 'Lagere commerciële beroepen' (621).

Van de totale ingaande en uitgaande forensenstromen heeft daarentegen slechts $20 \%$ betrekking op de technische beroepen, waarbij er bij de 'Middelbare technische, ambachts- en industrieberoepen' (302) sprake is van de grootste pendelstromen. De netto inkomende pendel bedraagt $8 \%$ voor dit beroepssegment. Een tweetal andere beroepssegmenten wordt gekenmerkt door relatief hoge pendelstromen, te weten: 'Hogere medische en paramedische beroepen' (503) en 'Hogere sociaal-culturele beroepen' (703). Daarbij bedraagt de netto inkomende pendel in beide gevallen slechts $2 \%$.

\subsection{Forensenstromen per opleidingstype}

In tabel 3.7 worden de forensenstromen per opleidingstype nader belicht. Uit de tabel blijkt dat lager opgeleiden doorgaans in de buurt van hun woonplaats werken. Bij de ongeschoolden $(0,1,2)$ is zowel de ingaande als de uitgaande pendel zeer laag, al is er bij deze groep toch sprake van een netto inkomende pendelstroom van 6\%. Op VBO-niveau is de pendel het grootste voor het 'VBO technisch' (331-339). Bij dit opleidingstype is er ook sprake van een relatief grote netto inkomende pendel van $7 \%$. Een groot deel van de inkomende en uitgaande pendel heeft betrekking op werkenden met een opleidingsachtergrond op MBO-niveau (inclusief 'Bovenbouw HAVO/VWO' (401)): $40 \%$ van de inkomende en $35 \%$ van de uitgaande pendelaars heeft een opleidingsachtergrond op dit niveau. De opleidingstypen 'MBO technisch' (436-439), 'MBO economisch-administratief' (453,461-464) en 'Bovenbouw HAVO/VWO' (401) vertonen daarbij het grootste verschil tussen de inkomende en uitgaande pendel. De pendelstromen zijn echter relatief het grootste bij de hoger opgeleiden (5-6). Van de totale uitgaande pendel heeft $35 \%$ een opleiding op HBO- of WO-niveau gevolgd, terwijl van de totale inkomende pendel circa $30 \%$ uit hoger opgeleiden (5-6) bestaat. Bij de in kaart gebrachte opleidingstypen is er sprake van een netto inkomende pendelstroom van circa 8.000 hoger opgeleiden (5-6). Bij de hoger technisch en economisch opgeleiden (5-6) zijn de pendelstromen verhoudingsgewijs het grootst. Van deze opleidingstypen woont circa $40 \%$ in een andere regio dan waar men werkt. 
Tabel 3.7. In- en uitgaande forensenstromen per opleidingstype, gemiddelde 1990-1991

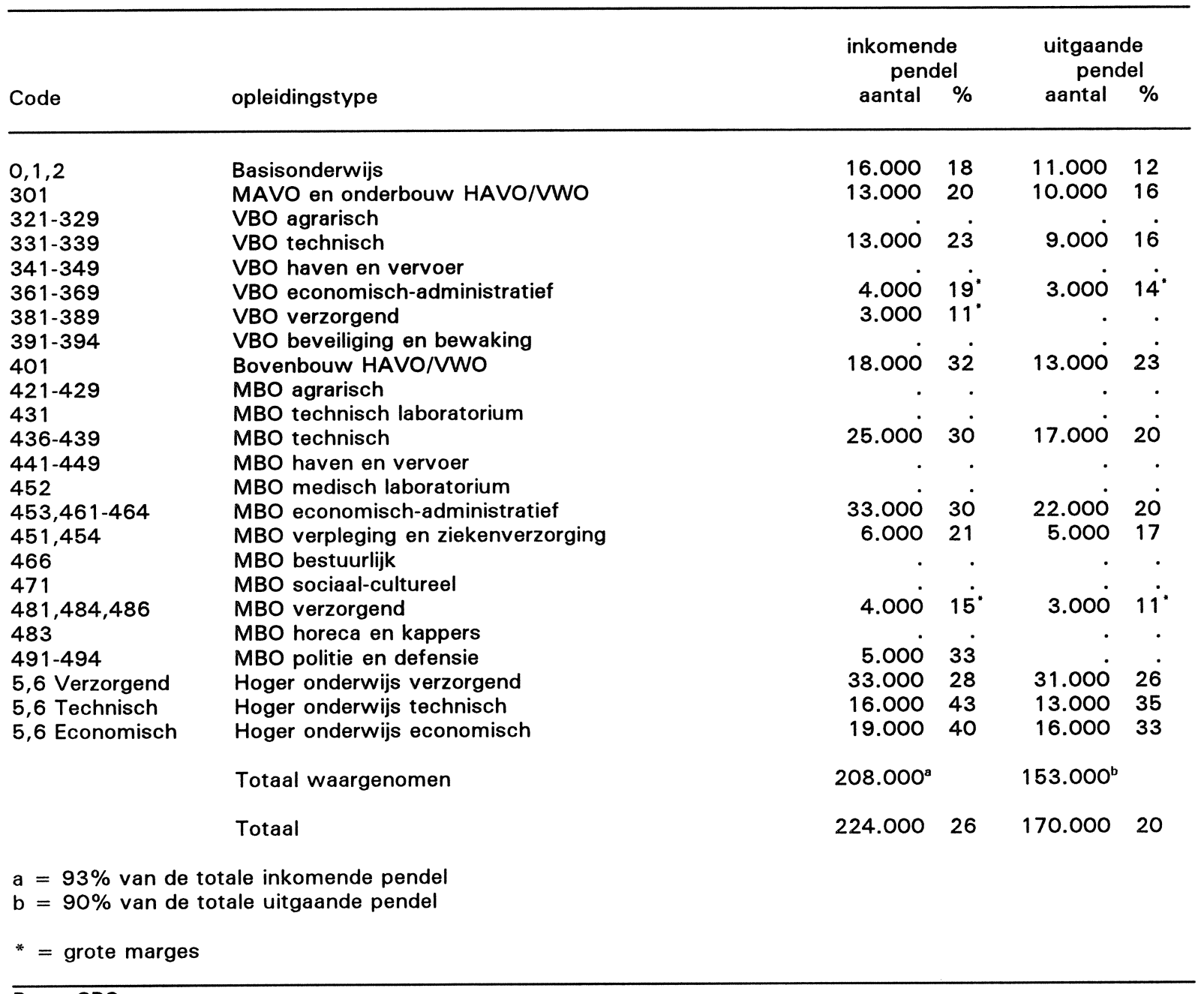

Bron: CBS

In tabel B.4 van bijlage B wordt per opleidingscategorie ${ }^{19}$ een overzicht gegeven van de belangrijkste beroepssectoren ${ }^{20}$ waarin veel RBA-grensoverschrijdend woon-werkverkeer plaatsvindt. In het algemeen kan worden opgemerkt dat er vooral regionale mobiliteit wordt gemeten in de beroepssectoren die nauw aansluiten op de opleidingsachtergrond van de werkenden. Voor de opleidingen op MBO-niveau blijkt uit de tabel dat de forensenstromen van de algemeen (401) en de economisch-administratief $(453,461-464)$ opgeleiden veelal betrekking hebben op de werkenden in de beroepssegmenten 'Lager en middelbare administratieve beroepen' (611-612) en 'Commerciële beroepen' (62). De verhoudingsgewijs grootste regionale mobiliteit bij 'MBO agrarisch, technisch, vervoer en laboratorium' $(42-44,452)$ vindt plaats in het beroepssegment 'Metaal, elektrotechnische, bouwmaterialen-, glas- en aardewerkberoepen'

19. In bijlage A wordt een overzicht gegeven van de in dit rapport onderscheiden opleidingscategorieën. Binnen het onderwijs op MAVO/VBO-niveau, wordt een onderscheid gemaakt tussen het algemeen onderwijs en het beroepsonderwijs. Het onderwijs op MBO-niveau wordt onderverdeeld in een viertal hoofdrichtingen.

20. In bijlage A wordt een overzicht gegeven van de in dit rapport onderscheiden beroepssectoren. 
(36-39). De werkenden met een andere opleidingsachtergrond op MBO-niveau (rest 4) worden gekenmerkt door relatief grote pendelstromen in de 'Medische en paramedische beroepen' (5) en de 'Verzorgende en dienstverlenende beroepen en openbare orde en veiligheidsberoepen' $(8,9)$. Dit is echter niet verwonderlijk aangezien in deze opleidingscategorie voornamelijk medische en verzorgende opleidingen zijn samengevoegd.

Voor de hoger opgeleiden (5-6) is het RBA-grensoverschrijdend woon-werkverkeer het grootste bij de 'Pedagogische, culturele en sociaal-culturele beroepen' $(0,1,7)$. In absolute zin is hierbij overigens de inkomende pendel gelijk aan de uitgaande pendel. Daarnaast komen er relatief grote forensenstromen voor bij een tweetal economisch-administratieve beroepen. Het gaat daarbij om de 'Lagere en middelbare administratieve beroepen' (611-612) en 'Hogere economisch-administratieve beroepen' $(60,613,63)$. Het verschil tussen de inkomende en uitgaande pendel is daarbij juist het grootst bij de 'Lagere en middelbare administratieve beroepen' (611-612), met een netto inkomende pendel van 3.000 personen. Voor de hoger opgeleiden zijn de forensenstromen in de technische beroepen (3) duidelijk kleiner, hetgeen het gevolg kan zijn van het feit dat hoger opgeleide technici nogal eens werkzaam zijn in leidinggevende beroepen.

De pendel bij werkenden met 'MAVO en onderbouw HAVO/VWO' heeft voornamelijk betrekking op de 'Lagere en middelbare administratieve beroepen' (611-612). Bij de werkzame personen met een VBO-opleiding is er met name sprake van een RBA-grensoverschrijdend woonwerkverkeer bij de 'Lagere en middelbare administratieve beroepen' (611-612). Daarnaast is de inkomende pendel voor de beroepssector 'Metaal-, elektrotechnische, bouwmaterialen-, glas- en aardewerkberoepen' (36-39) verhoudingsgewijs groot.

\subsection{Conclusie}

Het RBA-grensoverschrijdend woon-werkverkeer in de provincie Noord-Holland is in dit hoofdstuk nader belicht. In het algemeen kan worden geconcludeerd dat er sprake is van een netto inkomende pendel van 52.500 personen, dit is $6 \%$ van het aantal in de provincie werkzame personen. Binnen de provincie is er sprake van aanzienlijke pendelstromen vanuit NHN naar de beide aangrenzende RBA-gebieden. Daarnaast zijn er met name tussen de RBAgebieden KAM en AZW omvangrijke forensenstromen in beide richtingen. Bijna drie kwart van de pendelaars behoort tot de 25-49 jarigen. Daarbij zijn vooral de mannen regionaal mobiel.

$\mathrm{Er}$ is voornamelijk sprake is van aanzienlijke forensenstromen in die segmenten van de arbeidsmarkt die in de werkgelegenheidsstructuur van een bepaald RBA-gebied een belangrijke rol spelen. Zo heeft de aanwezigheid van de luchthaven Schiphol een duidelijke invloed op de forensenstromen. Daarnaast is er sprake van grote pendelstromen in de in KAM sterk vertegenwoordigde 'Metaal-, elektrotechnische, transportmiddelenindustrie' (33-39). De bedrijfssector 'Andere tertiaire diensten' $(67,68,81,82,84,85,98,99)$ wordt gekenmerkt door een grote netto inkomende pendel. Deze bedrijfssector is relatief sterk vertegenwoordigd in AZW. Met betrekking tot de beroepen kan worden opgemerkt dat de economisch-administra- 
tieve beroepen (6) verhoudingsgewijs grote pendelstromen kennen, terwijl de pendel in de technische beroepen (3) duidelijk lager is. De economische-administratieve beroepen (6) zijn daarbij al met al goed voor circa $40 \%$ van de totale inkomende pendel. Ook het opleidingsniveau van de werkenden is duidelijk van invloed op de omvang van het forensisme. De hoger opleiden (5-6) wonen verhoudingsgewijs vaak in een andere regio dan waar ze werken. Van de uitgaande pendel heeft maar liefst $35 \%$ betrekking op hoger opgeleiden. Daarentegen is de pendel bij de laag opgeleiden $(0,1,2,3)$ gering.

Met betrekking tot de in dit hoofdstuk gepresenteerde informatie moet worden opgemerkt dat, met name voor de onderscheiden beroepssegmenten en in mindere mate ook voor de opleidingstypen, slechts in beperkte mate betrouwbare informatie over pendelstromen kan worden verkregen. Voor de tabel die per opleidingscategorie een overzicht geeft van de inkomende en uitgaande pendelstromen van de beroepssectoren kan slechts in zeer beperkte mate betrouwbare informatie worden gegeven. Overeenkomstig hetgeen in hoofdstuk 2 reeds is opgemerkt, zou de hoeveelheid informatie en de betrouwbaarheid ervan kunnen toenemen als de gepresenteerde informatie naar beroep en opleiding op een hoger aggregatieniveau zou plaatsvinden. 


\section{BAANVINDERS}

\subsection{Inleiding}

Om meer inzicht te krijgen in de omvang en de aard van de baanmobiliteit in de provincie NoordHolland, kan worden gekeken naar het aantal baanvinders. Daarbij gaat het om degenen die op de enquêtedatum een werkkring in loondienst hadden waarin ze korter dan én jaar werkzaam waren (zie Bierings en Windmeijer, 1992) ${ }^{21}$. Het begrip baanvinders heeft hier, in tegenstelling tot het artikel van Bierings en Windmeijer (1992), niet alleen betrekking op degenen die op de enquêtedatum een werkkring in loondienst hadden, waarin ze korter dan éen jaar werkzaam zijn, maar ook op zelfstandigen en meewerkende gezinsleden.

Baanvinders kunnen mensen zijn die van werkkring zijn gewisseld (baan-baanmobiliteit), werklozen die een baan hebben gevonden, herintreders of nieuwkomers op de arbeidsmarkt. Deze vier groepen zullen hier niet expliciet worden onderscheiden. Wel zal het aantal baanvinders worden verbijzonderd naar bedrijfstak, beroepssector en opleidingscategorie. Daarbij zal ook telkens een indicatie worden gegeven van het percentage jongeren en vrouwen binnen de onderscheiden categorieën baanvinders. Als eerste wordt echter ingegaan op de regionale mobiliteit van de baanvinders en wordt een beeld geschetst van de betekenis van voltijd en deeltijd functies voor mannelijke en vrouwelijke baanvinders. De afsluitende paragraaf zet de belangrijkste conclusies op een rijtje.

Tabel 4.1. Aantal baanvinders naar woon-RBA en werk-RBA, gemiddelde 1989-1991

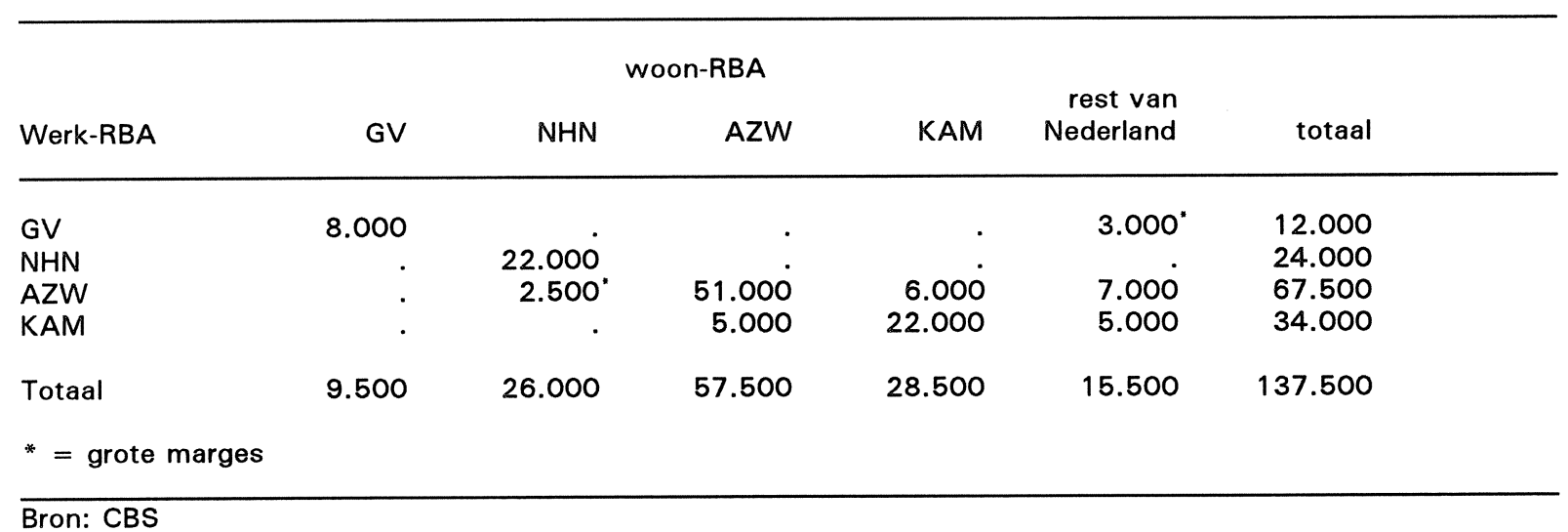

Tabel 4.1 geeft een overzicht van het RBA-grensoverschrijdend woon-werkverkeer onder de baanvinders binnen de provincie Noord-Holland. Daarnaast geeft de tabel aan hoeveel baanvinders niet in de provincie woonachtig $\mathrm{zijn}^{22}$. In totaal hebben de laatste jaren gemiddeld

21. Daarbij moet worden bedacht dat het feitelijk aantal baanvinders wordt onderschat, omdat degenen die in het afgelopen jaar een baan hebben gevonden en al weer zijn kwijtgeraakt niet worden meegenomen. Deze onderschatting zal vooral optreden bij seizoensgebonden arbeid.

22. Evenals in hoofdstuk 3, kan hier niet worden achterhaald hoeveel personen in Noord-Holland wonen en elders werken. 
jaarlijks 137.500 personen in het jaar voorafgaand aan de enquêtedatum een nieuwe werkkring gevonden. De woon- en werkregiospreiding van de deze baanvinders komt grotendeels overeen met die van de totale werkzame personen in Noord-Holland. Van de in Noord-Holland werkzame baanvinders is $11 \%$ niet in deze provincie woonachtig. Van de in GV werkende baanvinders, woont éen kwart buiten de provincie Noord-Holland. Daarentegen is veruit het grootste deel (92\%) van de in NHN werkzame baanvinders in hetzelfde RBA-gebied woonachtig. Van de baanvinders die in AZW werken, woont $76 \%$ in datzelfde RBA-gebied, terwijl $65 \%$ van de in KAM werkzame baanvinders in hetzelfde RBA-gebied woont. Overigens woont een aanzienlijke groep in AZW werkzame baanvinders in KAM (9\%), terwijl een niet veel kleinere groep baanvinders dat in KAM werkt, woonachtig is in AZW (5.000 baanvinders). In procenten van het totaal aantal baanvinders in KAM is deze laatstgenoemde groep zelfs groter $(15 \%)$. Bovendien is een aanzienlijk deel van de baanvinders die in deze twee RBA-gebieden werkzaam zijn, woonachtig buiten de provincie Noord-Holland.

Tabel 4.2. Aantal baanvinders naar wekelijkse arbeidstijd en geslacht, gemiddelde 1989-1991

\begin{tabular}{|c|c|c|c|}
\hline Arbeidsuren & mannen & vrouwen & totaal \\
\hline $\begin{array}{l}12-19 \text { uur } \\
20-34 \text { uur } \\
\geq 35 \text { uur }\end{array}$ & $\begin{array}{r}4.500^{\circ} \\
9.000 \\
57.000\end{array}$ & $\begin{array}{r}9.000 \\
20.000 \\
37.500\end{array}$ & $\begin{array}{l}13.500 \\
29.500 \\
94.500\end{array}$ \\
\hline $\begin{array}{l}\text { Totaal } \\
*=\text { grote marges }\end{array}$ & 70.500 & 67.000 & 137.500 \\
\hline
\end{tabular}

Bron: CBS

Uit tabel 4.2 blijkt dat bijna $70 \%$ van de baanvinders in de provincie Noord-Holland full-time (35 uur of meer per week) werkzaam is. Van de totale werkzame personen in Noord-Holland werkt $73 \% 35$ uur of meer per week. Vrouwen vormen bijna de helft van het totaal aantal baanvinders in de provincie, terwijl $40 \%$ van de totale werkzame personen uit vrouwen bestaat. Daarbij zijn vrouwen met name in deeltijdbanen terechtgekomen. Twee maal zoveel vrouwen als mannen hebben een nieuwe werkkring gevonden met een wekelijkse arbeidsduur van 12 tot 20 uur. Hetzelfde is het geval bij de banen van 20 tot 35 uur per week. Daarentegen is $60 \%$ van de banen van 35 uur of meer per week bij mannen terechtgekomen.

\subsection{Baanvinders per bedrijfstak}

In tabel 4.3 wordt het aantal baanvinders per bedrijfstak ${ }^{23}$ gepresenteerd, waarbij dit aantal tevens wordt gerelateerd aan het totaal aantal werkenden in de desbetreffende bedrijfstak ${ }^{24}$. Van het totaal aantal werkenden in de provincie Noord-Holland heeft $16 \%$ in het jaar

23. In bijlage A wordt een overzicht gegeven van de in dit rapport onderscheiden bedrijfstakken.

24. Hiervoor zijn de in hoofdstuk 2 besproken aantallen van de bedrijfsklassenstructuur van de werkgelegenheid gebruikt. Doordat beide sectorindelingen echter van elkaar afwijken, kunnen er afrondfouten zijn opgetreden bij het bepalen van de aantallen werkzame personen per bedrijfstak. 
voorafgaande aan de enquêtedatum een nieuwe werkkring gevonden. De bedrijfstakken 'Bouwnijverheid en -installatiebedrijven' (5) en 'Handel, hotel- en restaurantwezen, reparatiebedrijven voor gebruiksgoederen' (6) worden gekenmerkt door een relatief hoog percentage baanvinders. Daarentegen vallen de bedrijfstakken 'Vervoer en communicatie' (7) en 'Overige dienstverlening' (9) op door een verhoudingsgewijs laag percentage baanvinders. De overige bedrijfstakken wijken niet of nauwelijks af van het gemiddelde beeld. Absoluut gezien zijn de meeste baanvinders te vinden in de bedrijfstakken 'Handel, hotel- en restaurantwezen, reparatiebedrijven voor gebruiksgoederen' (6) en 'Overige dienstverlening' (9). Tezamen zijn beide sectoren goed voor $55 \%$ van het totaal aantal baanvinders in de provincie Noord-Holland.

Tabel 4.3. Aantal en percentage baanvinders per bedrijfstak, gemiddelde 1989-1991

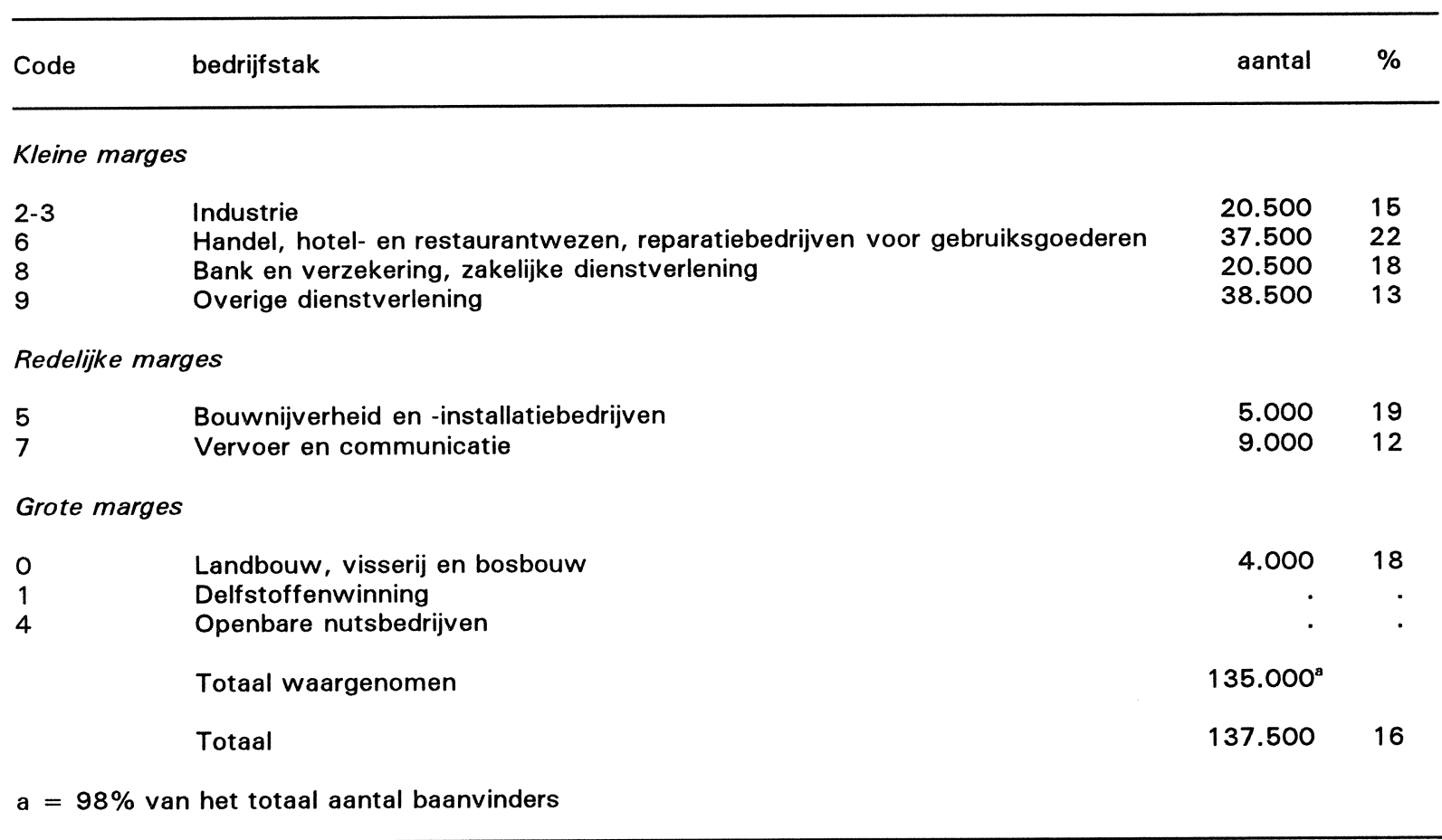

Bron: CBS

Tabel 4.4 schetst een beeld van het aandeel van jongeren en vrouwen in het totaal aantal baanvinders per bedrijfstak. Uit de tabel komt naar voren dat $43 \%$ van de baanvinders in NoordHolland jonger dan 25 jaar is. Bij de bedrijfstakken 'Industrie' (2-3) en 'Handel, hotel- en restaurantwezen, reparatiebedrijven voor gebruiksgoederen' (6) is circa $50 \%$ van de baanvinders jonger dan 25 jaar. Het percentage jongeren onder de baanvinders is verhoudingsgewijs laag bij de bedrijfstakken 'Bank en verzekering, zakelijke dienstverlening' (8) en 'Overige dienstverlening' (9). Mede gezien het hoge percentage vrouwen onder de baanvinders bij de laatstgenoemde bedrijfstak zijn er, naast de baan-baanmobiliteit, in deze bedrijfstak mogelijk veel herintredende vrouwen onder de baanvinders.

Zoals reeds eerder is opgemerkt vormen vrouwen bijna de helft van het totaal aantal baanvinders in de provincie Noord-Holland. Relatief veel vrouwelijke baanvinders zijn, zoals gezegd, te vinden in de bedrijfstak 'Overige dienstverlening' (9), hetgeen een bedrijfstak is 
waarin relatief veel vrouwen werken. Daarentegen zijn er in de bedrijfstak 'Industrie' (2-3) verhoudingsgewijs weinig vrouwen onder de baanvinders.

Tabel 4.4. Percentage jongeren en vrouwen in het aantal baanvinders per bedrijfstak, gemiddelde 1989-1991

\begin{tabular}{|c|c|c|c|}
\hline Code & bedrijfstak & $\begin{array}{r}r e n \\
\%\end{array}$ & $\begin{array}{r}\text { vrouwen } \\
\%\end{array}$ \\
\hline 0 & Landbouw, visserij en bosbouw & $63^{*}$ & . \\
\hline 1 & Delfstoffenwinning & & \\
\hline $2-3$ & Industrie & 49 & 34 \\
\hline 4 & Openbare nutsbedrijven & & . \\
\hline 5 & Bouwnijverheid en -installatiebedrijven & $50^{*}$ & \\
\hline 6 & Handel, hotel- en restaurantwezen, reparatiebedrijven voor gebruiksgoederen & 51 & 49 \\
\hline 7 & Vervoer en communicatie & $50^{*}$ & $33^{\circ}$ \\
\hline 8 & Bank en verzekering, zakelijke dienstverlening & 37 & 49 \\
\hline \multirow[t]{2}{*}{9} & Overige dienstverlening & 32 & 65 \\
\hline & Totaal & 43 & 49 \\
\hline$*=$ & ges & & \\
\hline
\end{tabular}

Bron: CBS

\subsection{Baanvinders per beroepssector}

Tabel 4.5 geeft een overzicht van het aantal baanvinders per beroepssector en het percentage van het totaal aantal werkenden dat als baanvinder kan worden getypeerd ${ }^{25}$. Het percentage baanvinders in de beroepssector 'Transportberoepen' (4) is verhoudingsgewijs hoog. Het percentage baanvinders in deze beroepssector is ook duidelijk hoger dan in de bedrijfstak 'Vervoer en communicatie' (7) (zie tabel 4.3). Verder heeft een relatief hoog percentage van de werkenden in de beroepssectoren 'Lagere en middelbare administratieve beroepen' (611-612), 'Commerciële beroepen' (62) en 'Verzorgende en dienstverlenende beroepen en openbare orde en veiligheidsberoepen' $(8,9)$ in het voorafgaande jaar een nieuwe werkkring gevonden. Absoluut gezien zijn de meeste baanvinders te vinden bij de 'Lagere en middelbare administratieve beroepen' (611-612). Ruim 25\% van het totaal aantal baanvinders is werkzaam in deze beroepssector.

Het percentage baanvinders is daarentegen verhoudingsgewijs laag bij de beroepssectoren 'Pedagogische, culturele en sociaal-culturele beroepen' $(0,1,7)$, 'Technische, ambachts- en industrieberoepen' (30) en 'Hogere economisch-administratieve beroepen' $(60,613,63)$. Zoals in hoofdstuk 2 reeds is opgemerkt, gaat het hierbij voornamelijk, om beroepssectoren waarin relatief veel arbeidskrachten van 25 jaar of ouder werkzaam zijn.

25. Hiervoor zijn de in hoofdstuk 2 besproken aantallen van de werkgelegenheidsstructuur per beroepssegment gebruikt. Doordat beide beroepenindelingen echter van elkaar afwijken, kunnen er afrondfouten zijn opgetreden bij het bepalen van de aantallen werkzame personen per beroepssector. 
Tabel 4.5. Aantal en percentage baanvinders per beroepssector, gemiddelde 1989-1991

\begin{tabular}{ll}
\hline Code beroepssector & aantal $\%$ \\
\hline
\end{tabular}

Kleine marges

2,31-35 Agrarische, voedings- en genotmiddelen-, textiel-,

hout- en papier-, grafische, chemische beroepen $\quad 11.000 \quad 17$

36-39 Metaal-, elektrotechnische, bouwmaterialen-, glas- en aardewerkberoepen $\quad 13.500 \quad 16$

$5 \quad$ Medische en paramedische beroepen $\quad 10.00015$

611-612 Lagere en middelbare administratieve beroepen $\quad 36.00019$

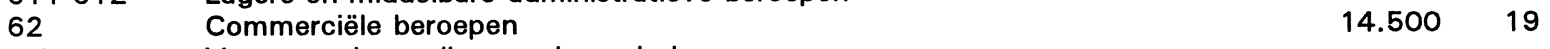

$\begin{array}{llll}8,9 & \begin{array}{l}\text { Verzorgende en dienstverlenende beroepen } \\ \text { en openbare orde- en veiligheidsberoepen }\end{array} & 20.000 & 19\end{array}$

Redelijke marges

$\begin{array}{llrr}0,1,7 & \text { Pedagogische, culturele en sociaal-culturele beroepen } & 9.500 & 10 \\ 30 & \text { Technische, ambachts- en industrieberoepen } & 6.500 & 10 \\ 4 & \text { Transportberoepen } & 9.500 & 20 \\ 60,613,63 & \text { Hogere economisch-administratieve beroepen } & 6.000 & 12 \\ & & 137.500 & 16\end{array}$

Bron: CBS

Tabel 4.6. Percentage jongeren en vrouwen in het aantal baanvinders per beroepssector, gemiddelde 1989-1991

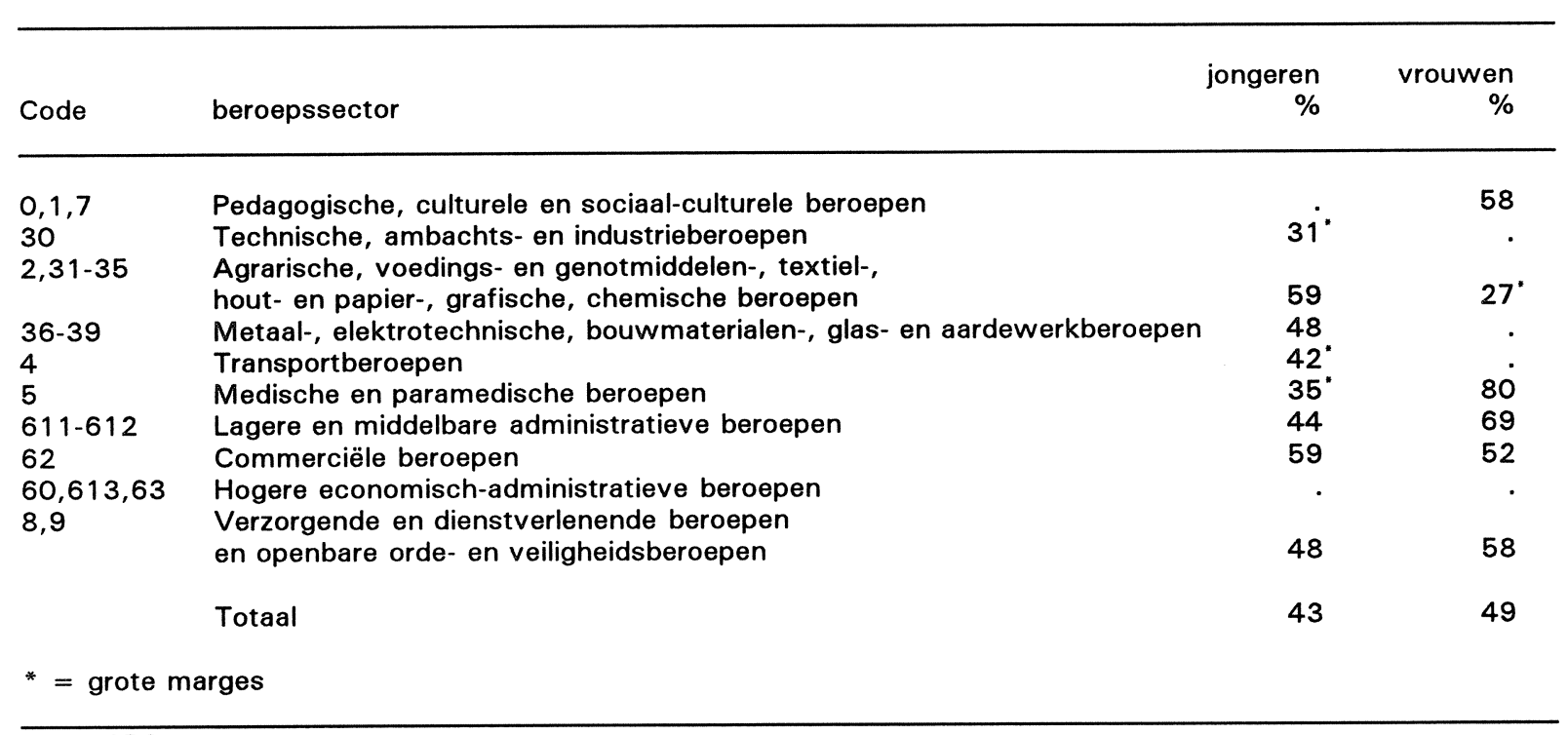

Bron: CBS

In tabel 4.6 wordt per beroepssector het percentage jongeren en vrouwen onder de baanvinders weergegeven. Het percentage baanvinders dat jonger is dan 25 jaar, is relatief hoog bij de 'Agrarische, voedings- en genotmiddelen-, textiel-, hout- en papier-, grafische, chemische beroepen' (2,31-35). Dit is in overeenstemming met het hoge percentage jongeren dat werkzaam is in de beroepssegmenten 'Agrarische beroepen' (2) en 'Lagere voedings- en genotmiddelenberoepen' (311) (zie tabel 2.10). Ook het hoge percentage baanvinders in de 'Commerciële beroepen' (62) dat jonger is dan 25 jaar, weerspiegelt het hoge percentage jongeren in het totaal aantal werkenden in deze beroepssector. Daarnaast is het percentage jonge baanvinders relatief hoog bij de 'Metaal-, elektrotechnische, bouwmaterialen-, glas- en 
aardewerkberoepen' (36-39) en de 'Verzorgende en dienstverlenende beroepen en openbare orde- en veiligheidsberoepen' $(8,9)$.

Het percentage vrouwelijke baanvinders is het hoogste bij de 'Medische en paramedische beroepen' (5); $80 \%$ van alle baanvinders in deze beroepssector is vrouw. Ook in de 'Lagere en middelbare administratieve beroepen' (611-612), de 'Pedagogische, culturele en sociaalculturele beroepen' $(0,1,7)$ en de 'Verzorgende en dienstverlenende beroepen en openbare ordeen veiligheidsberoepen' $(8,9)$ is het percentage vrouwen onder de baanvinders relatief hoog. Zoals uit tabel 2.13 kan worden afgeleid, gaat het hier veelal om typische vrouwenberoepen.

\subsection{Baanvinders per opleidingscategorie}

Tabel 4.7 geeft een overzicht van het aantal baanvinders per opleidingscategorie, waarbij dit aantal tevens wordt gerelateerd aan het totaal aantal werkenden in de desbetreffende opleidingscategorie $^{26}$. De opleidingscategorieën 'MAVO en onderbouw HAVO/VWO' (301) en 'Bovenbouw HAVO/VWO' (401) worden gekenmerkt door relatief hoge percentages baanvinders. Al met al heeft éen vijfde van het totaal aantal baanvinders in Noord-Holland een dergelijke algemene opleidingsachtergrond (301 en 401). Het grootste aantal baanvinders (bijna één derde) heeft echter betrekking op arbeidskrachten met een MBO-opleiding (4). De hoger opgeleiden (5-6) maken ruim één vijfde van het totaal aantal baanvinders uit.

Tabel 4.7. Aantal en percentage baanvinders per opleidingscategorie, gemiddelde 1989-1991

\begin{tabular}{|c|c|c|c|}
\hline Code & opleidingscategorie & aantal & $\%$ \\
\hline \multicolumn{4}{|l|}{ Kleine marges } \\
\hline $\begin{array}{l}0,1,2 \\
301 \\
\text { rest } 3 \\
401 \\
42-44,452 \\
453,461-464 \\
\text { rest } 4 \\
5-6\end{array}$ & $\begin{array}{l}\text { Basisonderwijs } \\
\text { MAVO en onderbouw HAVO/VWO } \\
\text { VBO } \\
\text { Bovenbouw HAVO/VWO } \\
\text { MBO agrarisch, technisch, vervoer en laboratorium } \\
\text { MBO economisch-administratief } \\
\text { MBO overig } \\
\text { Hoger onderwijs }\end{array}$ & $\begin{array}{l}16.000 \\
14.000 \\
22.000 \\
14.000 \\
15.000 \\
16.000 \\
13.000 \\
29.000\end{array}$ & $\begin{array}{l}18 \\
22 \\
18 \\
25 \\
14 \\
15 \\
14 \\
14\end{array}$ \\
\hline & Totaal (waargenomen) & 138.000 & 16 \\
\hline
\end{tabular}

Bron: CBS

Het percentage jongeren en vrouwen in het totaal aantal baanvinders per opleidingscategorie wordt in tabel 4.8 gepresenteerd. Hieruit blijkt dat de baanvinders met 'MAVO en onderbouw HAVO/VWO' (301), een VBO-opleiding (rest 3) of 'Bovenbouw HAVO/VWO' relatief jong zijn. In hoofdstuk 2 is reeds opgemerkt, dat het percentage jongeren met deze opleidingsachtergrond

26. Hiervoor zijn de in hoofdstuk 2 besproken aantallen van de werkgelegenheidsstructuur per opleidingstype gebruikt. Doordat beide opleidingenindelingen echter van elkaar afwijken, kunnen er afrondfouten zijn opgetreden bij het bepalen van de aantallen werkzame personen per opleidingscategorie. 
dat werkzaam is in de provincie Noord-Holland verhoudingsgewijs hoog is. Hierbij kan het enerzijds gaan om nieuwkomers op de arbeidsmarkt, maar anderzijds speelt ook het 'job shopping' een belangrijke rol. Het percentage baanvinders dat jonger is dan 25 jaar, is verhoudingsgewijs laag voor de opleidingscategorie 'MBO agrarisch, technisch, vervoer en laboratorium' (42-44,452).

Tabel 4.8. Percentage jongeren en vrouwen in het aantal baanvinders per opleidingscategorie, gemiddelde 19891991

\begin{tabular}{|c|c|c|c|}
\hline Code & opleidingscategorie & $\begin{array}{r}\text { jongeren } \\
\%\end{array}$ & $\begin{array}{r}\text { vrouwen } \\
\%\end{array}$ \\
\hline $\begin{array}{l}0,1,2 \\
301 \\
\text { rest } 3 \\
401 \\
42-44,452 \\
453,461-464 \\
\text { rest } 4 \\
5-6\end{array}$ & $\begin{array}{l}\text { Basisonderwijs } \\
\text { MAVO en onderbouw HAVO/VWO } \\
\text { VBO } \\
\text { Bovenbouw HAVO/VWO } \\
\text { MBO agrarisch, technisch, vervoer en laboratorium } \\
\text { MBO economisch-administratief } \\
\text { MBO overig } \\
\text { Hoger onderwijs }\end{array}$ & $\begin{array}{l}44 \\
64 \\
55 \\
57 \\
33 \\
44 \\
31 \\
14\end{array}$ & $\begin{array}{l}38 \\
50 \\
41 \\
50 \\
20 \\
63 \\
77 \\
52\end{array}$ \\
\hline & Totaal & 41 & 49 \\
\hline
\end{tabular}

Bron: CBS

Voor een tweetal opleidingscategorieën, namelijk 'MBO economisch-administratief' (453,461-464) en 'MBO overig' (rest 4) is het percentage vrouwen onder de baanvinders verhoudingsgewijs hoog. Bij het 'MBO overig' (rest 4) gaat het om een opleidingscategorie waarin met name medische en verzorgende opleidingen zijn samengevoegd. Bij deze opleidingen, evenals voor het 'MBO economisch-administratief' (453,461-464), is ook het percentage vrouwen in het totaal aantal werkenden relatief hoog. Daarnaast kan worden geconstateerd dat bij de hoger opgeleiden (5-6) iets meer dan de helft van de baanvinders vrouw is. Dit percentage is hoger dan het aandeel van vrouwen in het totaal aantal werkenden met een hogere opleiding $(44 \%)$. Relatief laag is het percentage vrouwen onder de ongeschoolde baanvinders, dat wil zeggen degenen met alleen 'Basisonderwijs' $(0,1,2)$. Aangenomen mag worden dat dit een indicatie vormt van de geringere participatie van ongeschoolde vrouwen in de betaalde arbeid, hetgeen ook uit tabel 2.14 valt af te lezen. Daarnaast wordt het 'VBO' (rest 3) gekenmerkt door een relatief laag percentage vrouwelijke baanvinders.

In tabel 4.9 wordt per RBA-gebied de verdeling van de baanvinders over de onderscheiden opleidingscategorieën gepresenteerd. Zoals bij tabel 4.7 al is geconstateerd hebben relatief veel baanvinders een hogere opleiding (5-6) voltooid. Dit is met name het geval in AZW. In hoofdstuk 2 is reeds opgemerkt dat veel werkzame hoger opgeleiden in dit RBA-gebied een opleidingsachtergrond in de verzorgende richting hebben. NHN wordt gekenmerkt door een relatief hoog percentage baanvinders met een VBO-opleiding (rest 3 ). 
Tabel 4.9. Percentage baanvinders naar werkregio per opleidingscategorie, gemiddelde 1990-1991

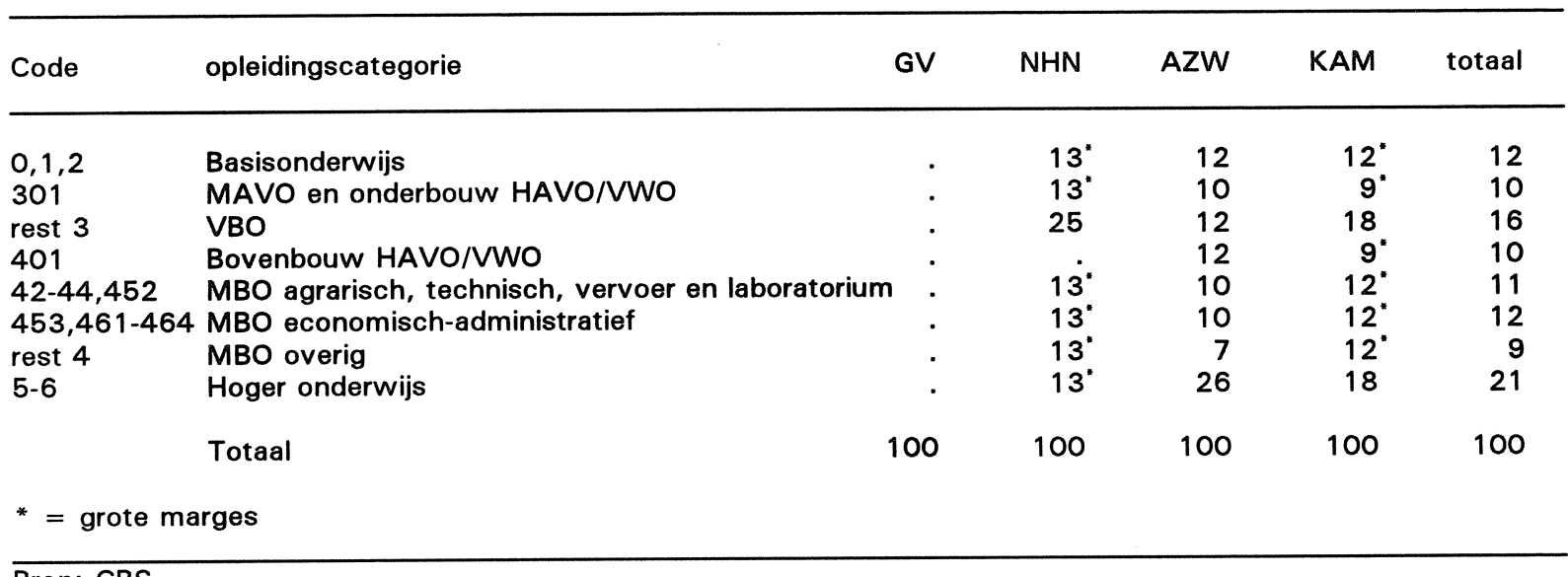

Bron: CBS

In tabel B.5 van bijlage B wordt per opleidingscategorie een overzicht gegeven van de belangrijkste beroepssectoren waar baanvinders met de desbetreffende opleidingsachtergrond terechtkomen. Van de baanvinders met 'MAVO en onderbouw HAVO/VWO' (301) en 'Bovenbouw HAVO/VWO' (401) is ruim 35\% werkzaam in de 'Lagere en middelbare administratieve beroepen' (611-612). Van de baanvinders met een economisch-administratieve opleiding op MBO niveau $(453,461-464)$ is bijna twee derde werkzaam in de 'Lagere en middelbare administratieve beroepen' (611-612). Ook van de hoger opgeleide baanvinders (5-6) is nog bijna $25 \%$ werkzaam in de 'Lagere en middelbare administratieve beroepen' (611-612). In hoofdstuk 2 is reeds naar voren gekomen, dat van de werkzame personen met 'Hoger onderwijs economisch' een relatief groot percentage werkzaam is in de beroepssegmenten 'Secretaressen, typisten' (6122) en 'Boekhoudkundige, belasting- en bankemployées' (6124). Wellicht dat het bij baanvinders echter deels gaat om startfuncties van nieuwkomers op de arbeidsmarkt, waarbij doorgroei naar een hoger functieniveau mogelijk is in een latere fase van de loopbaan (zie ook De Grip, Heijke en Willems, 1992). Daarnaast is ongeveer één vijfde van de baanvinders met een hogere opleiding (5-6) werkzaam in de 'Pedagogische, culturele en sociaal-culturele beroepen' $(0,1,7)$.

\subsection{Conclusie}

In dit hoofdstuk is de positie van baanvinders op de arbeidsmarkt in beeld gebracht. Daarbij stond achtereenvolgens de sector-, beroepen- en opleidingenstructuur van de werkgelegenheid van baanvinders centraal. Al met al is in de periode 1998-1991 gemiddeld $16 \%$ van de werkenden in de provincie Noord-Holland korter dan eén jaar in een nieuwe werkkring werkzaam geweest. Deze baanvinders kunnen mensen zijn die van werkkring zijn gewisseld of werklozen die een baan hebben gevonden, maar ook nieuwkomers op de arbeidsmarkt of herintredende vrouwen. Vrouwen maken in het algemeen de helft uit van het totaal aantal baanvinders in de provincie, hetgeen kan duiden op een toenemende participatiegraad van vrouwen en/of een grotere baan-baanmobiliteit. Overigens hebben vrouwen voornamelijk in deeltijdbanen werk gevonden. 
Verder blijkt dat het aantal baanvinders in de bedrijfstakken 'Handel, hotel- en restaurantwezen, reparatiebedrijven voor gebruiksgoederen' (6) en 'Bouwnijverheid en -installatiebedrijven' (5) en in de beroepssectoren 'Lager en middelbare administratieve beroepen' (611-612), 'Commerciële beroepen' (62) en 'Verzorgende en dienstverlenende beroepen en openbare orde- en veiligheidsberoepen' $(8,9)$ verhoudingsgewijs hoog is. Veel baanvinders zijn er ook onder de werkenden met een algemene opleidingsachtergrond (301 en 401).

Veel vrouwelijke baanvinders zijn te vinden in enkele duidelijke vrouwenberoepen. Het gaat daarbij met name om de 'Medische en paramedische beroepen' (5) en de 'Lagere en middelbare administratieve beroepen' (611-612). Bijna twee derde van de baanvinders in de 'Overige dienstverlening' (9) is vrouw. De jongere baanvinders komen veelal in de 'Agrarische, voedingsen genotmiddelen-, textiel-, hout- en papier-, grafische, chemische beroepen' (2,31-35) en de 'Commerciële beroepen' (62) terecht en zijn ook vaak werkzaam in de bedrijfstakken 'Industrie' (2-3) en 'Handel, hotel- en restaurantwezen, reparatiebedrijven voor gebruiksgoederen' (6).

Voor wat betreft de mogelijkheden om op basis van de EBB regionale arbeidsmarktinformatie over baanvinders te presenteren, kan worden geconcludeerd dat op een hoog aggregatieniveau van branche, beroep en opleiding vrij veel betrouwbare gegevens kunnen worden gepresenteerd. De verbijzondering naar RBA-gebied, leeftijd en geslacht heeft echter gevolgen voor de hoeveelheid informatie die kan worden weergegeven. Ook voor de tabel waar de informatie over baanvinders per opleidingscategorie wordt verbijzonderd naar de beroepssectoren kan slechts in beperkte mate betrouwbare informatie worden gegeven. Niet alleen kan er voor veel cellen van de desbetreffende matrix geen informatie worden gepresenteerd, maar ook het aantal werkenden in de cellen waarover wel gepubliceerd kan worden, wordt kleiner, waardoor de betrouwbaarheid van de informatie afneemt. 


\section{VERSCHILLEN IN WERKGELEGENHEIDSSTRUCTUUR}

\subsection{Inleiding}

In dit hoofdstuk komen de verschillen in de werkgelegenheidsstructuur tussen de werkzame personen, de inkomende en uitgaande forensenstromen en de baanvinders aan de orde. Alvorens een beeld wordt geschetst van de verschillen in de sector-, beroepen- en opleidingenstructuur wordt ingegaan, wordt eerst ingegaan op een aantal algemene aspecten: de werkgelegenheidsstructuur voor jongeren, vrouwen en de wekelijkse arbeidstijd naar geslacht.

Tabel 5.1. Vergelijking van de werkgelegenheidsstructuur van jongeren en vrouwen tussen werkzame personen, inkomende en uitgaande pendel en baanvinders

\begin{tabular}{lrrrr}
\hline & $\begin{array}{r}\text { werkzame } \\
\text { personen } \\
\%\end{array}$ & $\begin{array}{r}\text { inkomende } \\
\text { pendel } \\
\%\end{array}$ & $\begin{array}{r}\text { uitgaande } \\
\text { pendel } \\
\%\end{array}$ & $\begin{array}{r}\text { baan- } \\
\text { vinders } \\
\%\end{array}$ \\
\hline $\begin{array}{l}\text { Jongeren (15-24 jaar oud) } \\
\text { Vrouwen }\end{array}$ & 16 & 14 & 13 & 43 \\
\hline
\end{tabular}

Bron: CBS

Tabel 5.1. geeft een overzicht van het aandeel van jongeren en vrouwen in de werkgelegenheid van de onderscheiden groepen. Uit de tabel blijkt dat het percentage jongeren bij de baanvinders beduidend hoger is dan het percentage jongeren in het totaal aantal werkenden in de provincie Noord-Holland. Het werkgelegenheidsaandeel van jongeren in de pendelstromen komt overeen met het aandeel in de totale werkgelegenheid van deze leeftijdsgroep. Vrouwen blijken veelal in de eigen regio werkzaam te zijn. Zowel bij de inkomende als bij de uitgaande pendel zijn vrouwen sterk ondervertegenwoordigd. Daarentegen zijn vrouwen sterk vertegenwoordigd bij de baanvinders.

Tabel 5.2. Vergelijking van de werkgelegenheidsstructuur naar geslacht en wekelijkse arbeidstijd tussen werkzame personen en baanvinders

\begin{tabular}{llrrr}
\hline & $\begin{array}{r}\text { werkzame personen } \\
\text { mannen } \\
\%\end{array}$ & $\begin{array}{r}\text { vrouwen } \\
\%\end{array}$ & $\begin{array}{r}\text { baanvinders } \\
\text { mannen } \\
\%\end{array}$ & $\begin{array}{r}\text { vrouwen } \\
\%\end{array}$ \\
\hline $12-19$ uur & 2 & 15 & $6^{*}$ & 13 \\
$20-34$ uur & 9 & 36 & 13 & 30 \\
$\geq 35$ uur & 89 & 50 & 81 & 56 \\
Totaal & 100 & 100 & 100 & 100 \\
\hline * grote marges & & & & \\
\hline
\end{tabular}

Bron: CBS

In tabel 5.2. wordt het verschil in de wekelijkse arbeidsduur tussen de werkzame personen en 
de baanvinders in beeld gebracht ${ }^{27}$. Van de vrouwen die in het jaar voorafgaande aan de enquêtedatum een nieuwe werkkring hebben gevonden, heeft $56 \%$ een baan van 35 uur per week of meer. Van alle werkzame vrouwen in de provincie Noord-Holland heeft $50 \%$ een fulltime baan. Bij mannen is het omgekeerde beeld te zien. Bij de mannelijke baanvinders zijn de full-time werkenden enigszins ondervertegenwoordigd, al is nog steeds ruim $80 \%$ full-time werkzaam.

\subsection{Verschillen in de sectorstructuur}

Omdat de gehanteerde indelingen niet eenduidig tot elkaar herleidbaar zijn, wordt de sectorale werkgelegenheidsstructuur van de werkzame personen op verschillende aggregatieniveaus vergeleken met enerzijds de sectorstructuur van de forensenstromen (zie tabel 5.3) en anderzijds de sectorale werkgelegenheidsstructuur van de baanvinders (zie tabel 5.4).

Tabel 5.3. Vergelijking van de sectorstructuur van de werkgelegenheid tussen werkzame personen en inkomende en uitgaande pendel

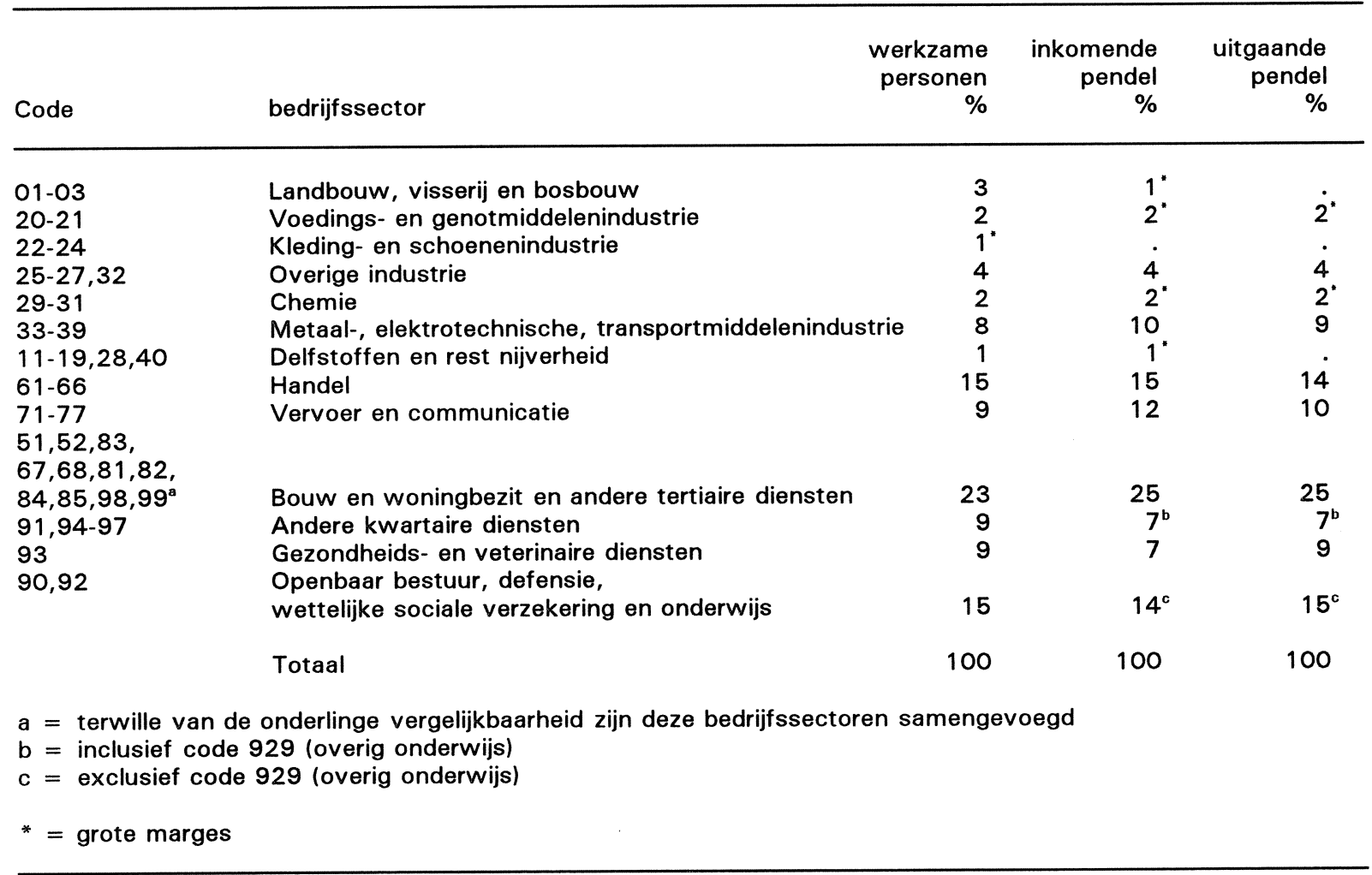

Bron: CBS

Uit tabel 5.3 blijkt dat de grootste verschillen in de werkgelegenheidsstructuur tussen de werkenden en de pendelstromen voorkomen bij de bedrijfssector 'Vervoer en communicatie' (71-77). Deze sector is oververtegenwoordigd bij de inkomende en uitgaande forensenstromen. Met name bij de inkomende pendel is deze sector relatief belangrijk. Bij de bedrijfssectoren

27. Bij de pendelstromen is op dit punt geen informatie voorhanden. 
'Metaal-, elektrotechnische, transportmiddelenindustrie' (33-39) en 'Bouw en woningbezit en andere tertiaire diensten' $(51,52,67,68,81-85,98,99)$ is er ook sprake van relatief grote pendelstromen. Het omgekeerde beeld is te zien bij de bedrijfssector 'Andere kwartaire diensten' (91,94-97). Het in deze tabel gesignaleerde verschil zal in werkelijkheid nog iets groter zijn, omdat de bedrijfsgroep 'Overig onderwijs' (929) bij de werkzame personen niet tot deze categorie is gerekend, terwijl dit bij de forensenstromen wel het geval is. De inkomende pendel bij de sector 'Gezondheids- en veterinaire diensten' (93) is relatief laag in vergelijking met zowel de werkzame personen als de uitgaande pendel.

Tabel 5.4. Vergelijking van de sectorstructuur van de werkgelegenheid tussen werkzame personen en baanvinders

\begin{tabular}{|c|c|c|c|}
\hline Code & bedrijfstak & $\begin{array}{r}\text { werkzame } \\
\text { personen } \\
\%\end{array}$ & $\begin{array}{r}\text { baan- } \\
\text { vinders } \\
\%\end{array}$ \\
\hline 0 & Landbouw, visserij en bosbouw & 3 & $3^{*}$ \\
\hline 1 & Delfstoffenwinning & & \\
\hline $2-3$ & Industrie & 16 & 15 \\
\hline 4 & Openbare nutsbedrijven & 1 & . \\
\hline 5 & Bouwnijverheid en installatiebedrijven & 3 & 4 \\
\hline 6 & $\begin{array}{l}\text { Handel, hotel- en restaurantwezen, reparatiebedrijven } \\
\text { voor gebruiksgoederen }\end{array}$ & 20 & 27 \\
\hline 7 & Vervoer en communicatie & 9 & 7 \\
\hline 8 & Bank en verzekering, zakelijke dienstverlening & 13 & 15 \\
\hline \multirow[t]{2}{*}{9} & Overige dienstverlening & 35 & 28 \\
\hline & Totaal & 100 & 100 \\
\hline$*=$ & & & \\
\hline
\end{tabular}

Bron: CBS

Tabel 5.4 geeft aan dat in de bedrijfstakken 'Handel, hotel- en restaurantwezen, reparatiebedrijven voor gebruiksgoederen' (6) en 'Overige dienstverlening' (9) grote verschillen optreden in de sectorale werkgelegenheidsstructuur tussen de totale werkzame personen en de baanvinders. De eerstgenoemde bedrijfstak is oververtegenwoordigd bij de baanvinders. Bij de 'Overige dienstverlening' (9) is het aantal baanvinders daarentegen relatief laag.

\subsection{Verschillen in de beroepenstructuur}

Tabel 5.5 geeft een overzicht van de werkgelegenheidsstructuur naar beroep voor de vier onderscheiden groepen. Uit de tabel blijkt dat de inkomende en uitgaande pendelstromen relatief groot zijn bij de 'Hogere economisch-administratieve beroepen' $(60,613,63)$. Bij de 'Pedagogische, culturele en sociaal-culturele beroepen' $(0,1,7)$ is de uitgaande pendel relatief groot. Bij deze laatstgenoemde beroepssector is er tevens sprake van een oververtegenwoordiging in de uitgaande pendel ten opzichte van de inkomende forensenstromen. De beroepssectoren 'Metaal, elektrotechnische, bouwmaterialen-, glas- en aardewerkberoepen' (36-39) en 'Verzorgende en dienstverlenende beroepen en openbare orde- en veiligheidsberoepen' $(8,9)$ zijn ondervertegenwoordigd in de inkomende en uitgaande forensenstromen. Bij 
de 'Lagere en middelbare administratieve beroepen' (611-612) is de uitgaande pendel relatief laag. Bij de 'Metaal, elektrotechnische, bouwmaterialen-, glas- en aardewerkberoepen' (36-39) is het werkgelegenheidsaandeel van deze beroepssector in de uitgaande pendel beduidend lager dan in de inkomende pendel. Ook bij de 'Lagere en middelbare administratieve beroepen' (611-612) is de uitgaande pendel enigszins ondervertegenwoordigd ten opzichte van de inkomende pendel.

Bij de 'Lagere en middelbare administratieve beroepen' (611-612) en de 'Verzorgende en dienstverlenende beroepen en openbare orde- en veiligheidsberoepen' $(8,9)$ zijn er relatief veel baanvinders. Daarentegen kennen de 'Technische, ambachts- en industrieberoepen' (30) relatief weinig baanvinders. Hetzelfde geldt ook voor de 'Pedagogische, culturele en sociaal-culturele beroepen' $(0,1,7)$.

Tabel 5.5. Vergelijking van de beroepenstructuur van de werkgelegenheid tussen werkzame personen, inkomende en uitgaande pendel en baanvinders

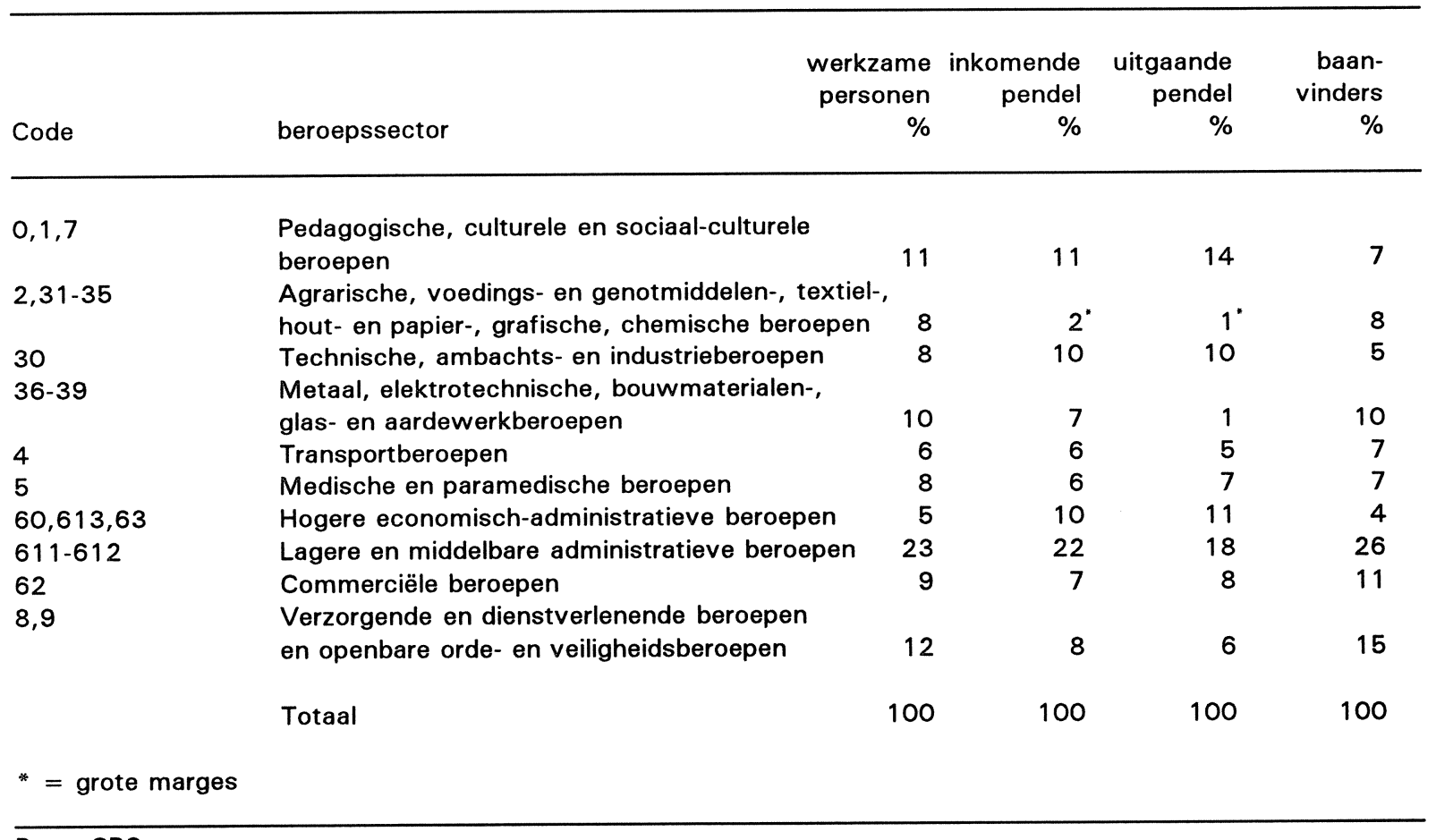

Bron: CBS

In tabel 5.6 wordt de beroepenstructuur van de jongeren die in de provincie Noord-Holland werkzaam zijn, vergeleken met de beroepenstructuur van de jongeren die in het jaar voorafgaande aan de enquêtedatum een nieuwe werkkring hebben gevonden. Voor slechts een tweetal beroepssectoren is er tussen beide groepen sprake van enig verschil in het werkgelegenheidsaandeel. Van de baanvinders jonger dan 25 jaar, is $16 \%$ werkzaam in de beroepssector 'Verzorgende en dienstverlenende beroepen en openbare orde- en veiligheidsberoepen' $(8,9)$. Het aandeel van deze beroepssector in de totale werkgelegenheid van jongeren in de provincie Noord-Holland bedraagt $13 \%$. Van het totaal aantal werkende jongeren in de provincie Noord-Holland is $9 \%$ werkzaam in de 'Agrarische, voedings- en genotmiddelen-, 
textiel-, hout- en papier-, grafische, chemische beroepen' (2,31-35), hetgeen $2 \%$-punten lager is dan het percentage baanvinders jonger dan 25 jaar dat in deze beroepssector werkzaam is. Bij de overige beroepssectoren is er geen sprake van over- noch ondervertegenwoordiging van het werkgelegenheidsaandeel van baanvinders jonger dan 25 jaar ten opzichte van de totale werkzame personen.

Tabel 5.6. Beroepenstructuur van de werkgelegenheid van jongeren, werkzame personen en baanvinders

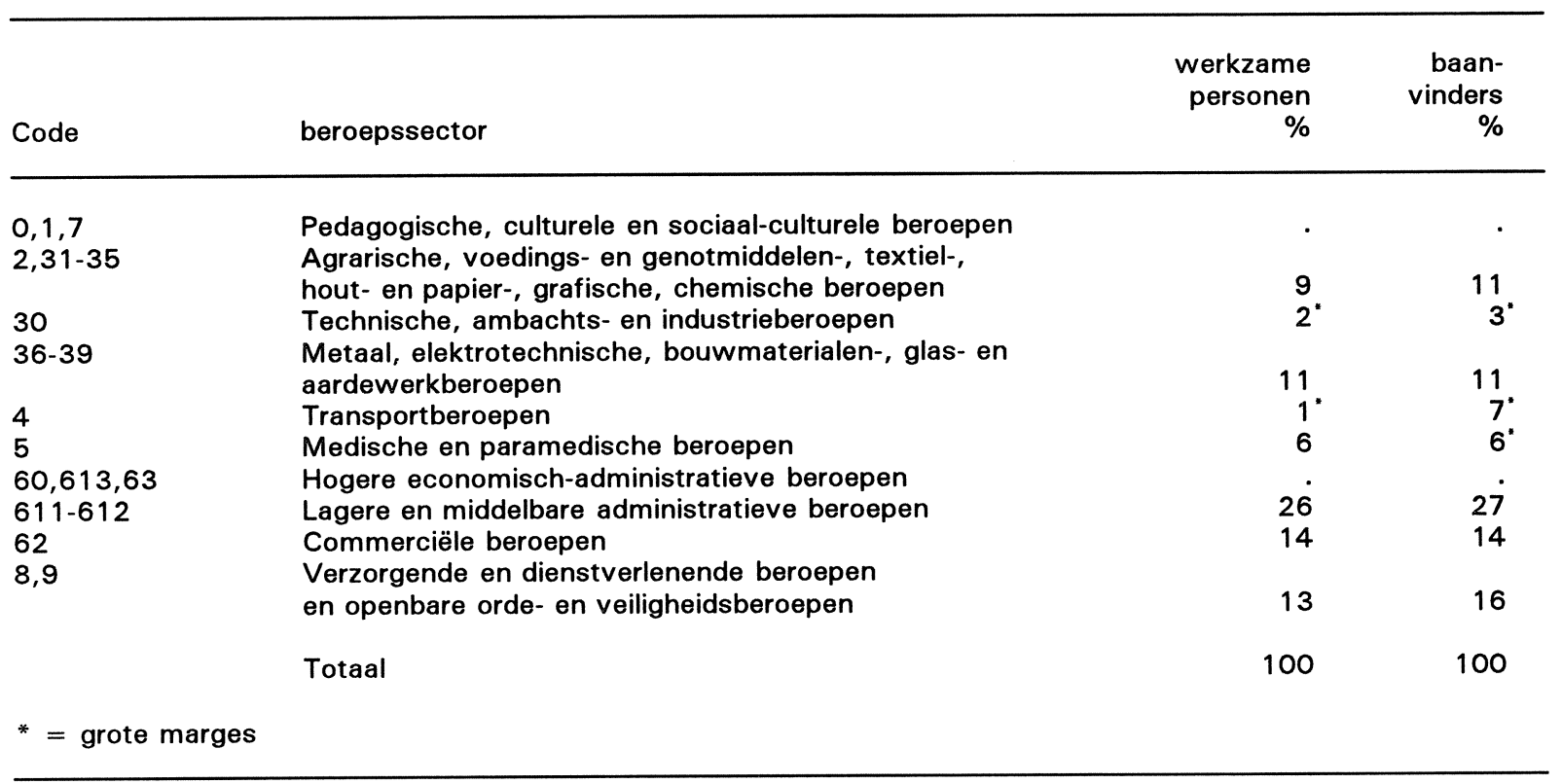

Bron: CBS

Tabel 5.7. Beroepenstructuur van de werkgelegenheid van vrouwen, werkzame personen en baanvinders

\begin{tabular}{|c|c|c|c|}
\hline Code & beroepssector & $\begin{array}{r}\text { werkzame } \\
\text { personen } \\
\%\end{array}$ & $\begin{array}{r}\text { baan- } \\
\text { vinders } \\
\%\end{array}$ \\
\hline $\begin{array}{l}0,1,7 \\
2,31-35\end{array}$ & $\begin{array}{l}\text { Pedagogische, culturele en sociaal-culturele beroepen } \\
\text { Agrarische, voedings- en genotmiddelen-, textiel-, } \\
\text { hout- en papier-, grafische, chemische beroepen }\end{array}$ & $\begin{array}{r}14 \\
3\end{array}$ & 8 \\
\hline $\begin{array}{l}30 \\
36-39\end{array}$ & $\begin{array}{l}\text { Technische, ambachts- en industrieberoepen } \\
\text { Metaal, elektrotechnische, bouwmaterialen-, glas- en } \\
\text { aardewerkberoepen }\end{array}$ & 2 & . \\
\hline 4 & Transportberoepen & $i$ & : \\
\hline 5 & Medische en paramedische beroepen & 14 & 12 \\
\hline $60,613,63$ & Hogere economisch-administratieve beroepen & 3 & \\
\hline $\begin{array}{l}611-612 \\
62\end{array}$ & $\begin{array}{l}\text { Lagere en middelbare administratieve beroepen } \\
\text { Commerciële beroepen }\end{array}$ & $\begin{array}{l}34 \\
10\end{array}$ & $\begin{array}{l}37 \\
11\end{array}$ \\
\hline \multirow{3}{*}{8,9} & Verzorgende en dienstverlenende beroepen & & \\
\hline & en openbare orde- en veiligheidsberoepen & 16 & 17 \\
\hline & Totaal & 100 & 100 \\
\hline \multicolumn{2}{|c|}{$*$ = grote marges } & & \\
\hline
\end{tabular}

Bron: CBS

Tabel 5.7 geeft inzicht in de verschillen tussen de beroepenstructuur van het totaal aantal in Noord-Holland werkende vrouwen en de beroepenstructuur van vrouwen die in het jaar 
voorafgaande aan de enquêtedatum een nieuwe werkkring hebben gevonden. Van de vrouwelijke baanvinders is maar liefst $37 \%$ werkzaam in de 'Lagere en middelbare administratieve beroepen' (611-612), terwijl het werkgelegenheidsaandeel van deze beroepssector in het totaal aantal vrouwen dat werkzaam is in de provincie Noord-Holland $34 \%$ bedraagt. Van de werkende vrouwen in Noord-Holland is $14 \%$ werkzaam in de 'Pedagogische, culturele en sociaal-culturele beroepen' $(0,1,7)$. Het percentage vrouwelijke baanvinders dat in deze beroepen werk heeft gevonden, ligt hier duidelijk onder; het werkgelegenheidsaandeel bedraagt in dat geval $8 \%$. Verder is er sprake van een klein verschil in het werkgelegenheidsaandeel tussen beide groepen bij de 'Medische en paramedische beroepen' (5). De totale werkgelegenheid voor vrouwen in deze beroepen is $2 \%$-punten hoger dan het werkgelegenheidsaandeel voor vrouwelijke baanvinders in deze beroepssector.

\subsection{Verschillen in de opleidingenstructuur}

Tabel 5.8 geeft een overzicht van de werkgelegenheidsstructuur naar opleiding voor de vier onderscheiden groepen. In vergelijking met aandeel in het totaal aantal werkenden in NoordHolland zijn de ongeschoolden $(0,1,2)$ en de VBO-ers (rest 3) ondervertegenwoordigd in de inkomende en uitgaande forensenstromen. De inkomende en uitgaande pendelstromen zijn daarentegen relatief hoog voor de hoger opgeleiden (5-6). Bij deze opleidingscategorie is er ook sprake van oververtegenwoordiging in de uitgaande pendel ten opzichte van de inkomende pendel. De hoger opgeleiden (5-6) hebben ook een relatief klein aandeel in het totaal aantal baanvinders. De MAVO-ers (301) en HAVO/VWO-ers (401) zijn oververtegenwoordigd bij de baanvinders.

Tabel 5.8. Vergelijking van de opleidingenstructuur van de werkgelegenheid tussen werkzame personen, inkomende en uitgaande pendel en baanvinders

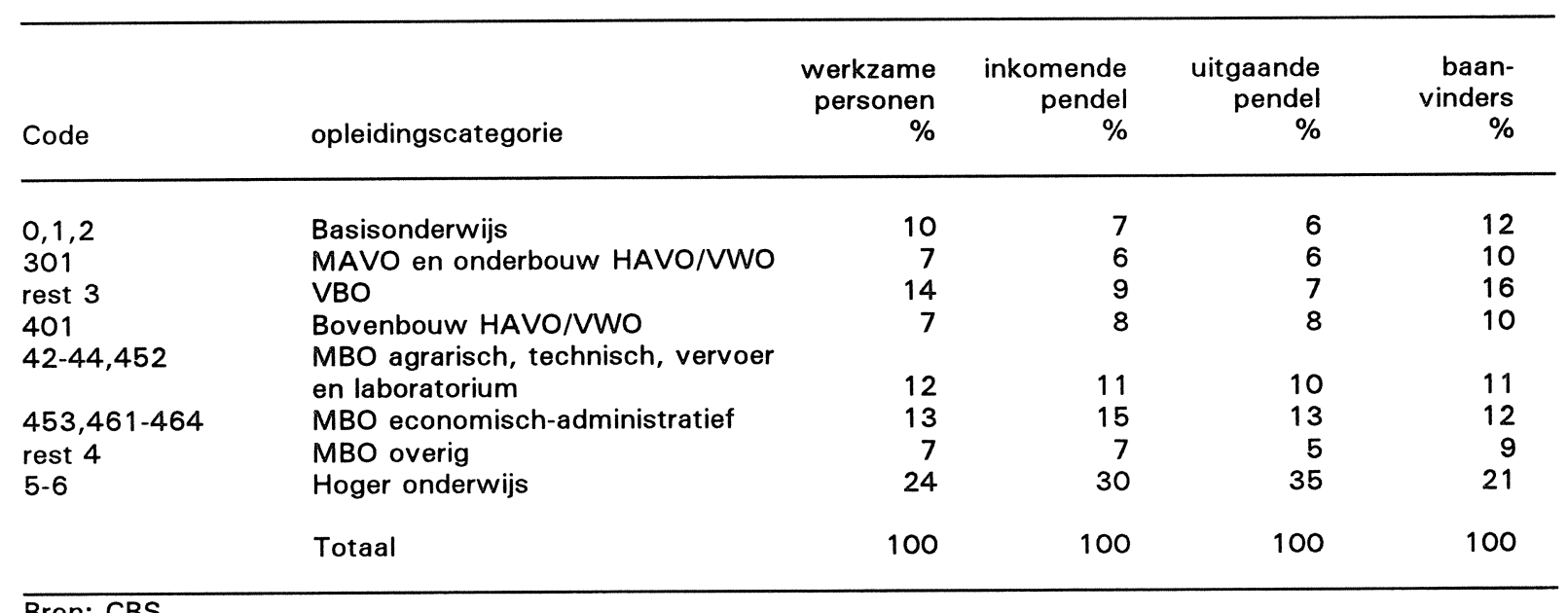

Bron: CBS

Tabel 5.9 vergelijkt de opleidingenstructuur van de jongeren die in de provincie Noord-Holland werkzaam met de opleidingenstructuur van de jongeren die in het jaar voorafgaande aan de enquêtedatum een nieuwe werkkring hebben gevonden. Voor slechts een tweetal opleidingscategorieën is er sprake van enige verschil in het werkgelegenheidsaandeel. Evenals in tabel 5.8 
naar voren kwam, zijn de MAVO-ers en HAVO/VWO-ers (301 en 401) oververtegenwoordigd bij de baanvinders, respectievelijk met $3 \%$-punten en $2 \%$-punten. Het werkgelegenheidsaandeel van de ongeschoolden $(0,1,2)$ is bij de baanvinders $2 \%$-punten hoger dan bij het totaal aantal werkzame personen. Bij de overige opleidingscategorieën is het verschil in het werkgelegenheidsaandeel tussen de werkzame personen en de baanvinders gering.

Tabel 5.9. Opleidingenstructuur van de werkgelegenheid van jongeren, werkzame personen en baanvinders

\begin{tabular}{|c|c|c|c|}
\hline Code & opleidingscategorie & $\begin{array}{r}\text { werkzame } \\
\text { personen } \\
\%\end{array}$ & $\begin{array}{r}\text { baan- } \\
\text { vinders } \\
\%\end{array}$ \\
\hline $\begin{array}{l}0,1,2 \\
301 \\
\text { rest } 3 \\
401 \\
42-44,452 \\
453,461-464 \\
\text { rest } 4 \\
5-6\end{array}$ & $\begin{array}{l}\text { Basisonderwijs } \\
\text { MAVO en onderbouw HAVO/VWO } \\
\text { VBO } \\
\text { Bovenbouw HAVO/VWO } \\
\text { MBO agrarisch, technisch, vervoer en laboratorium } \\
\text { MBO economisch-administratief } \\
\text { MBO overig } \\
\text { Hoger onderwijs }\end{array}$ & $\begin{array}{r}10 \\
13 \\
21 \\
12 \\
9 \\
13 \\
7 \\
5\end{array}$ & $\begin{array}{r}12 \\
16 \\
21 \\
14 \\
9 \\
12 \\
7 \\
7\end{array}$ \\
\hline & Totaal & 100 & 100 \\
\hline
\end{tabular}

Bron: CBS

In tabel 5.10 wordt het verschil tussen de opleidingenstructuur van het totaal aantal in NoordHolland werkende vrouwen en de opleidingenstructuur van vrouwen die in het jaar voorafgaande aan de enquêtedatum een nieuwe werkkring hebben gevonden, weergegeven. Van de vrouwen die recentelijk een nieuwe werkkring hebben gevonden heeft $22 \%$ hoger onderwijs (5-6) gevolgd, terwijl het aandeel van de hoger opgeleiden (5-6) in het totaal aantal vrouwen dat werkzaam is in de provincie Noord-Holland $26 \%$ bedraagt. Van de werkende vrouwen in NoordHolland heeft $7 \%$ en HAVO/VWO-opleiding (401) voltooid. Het percentage vrouwelijke baanvinders met deze opleiding is $3 \%$-punten hoger.

Tabel 5.10. Opleidingenstructuur van de werkgelegenheid van vrouwen, werkzame personen en baanvinders

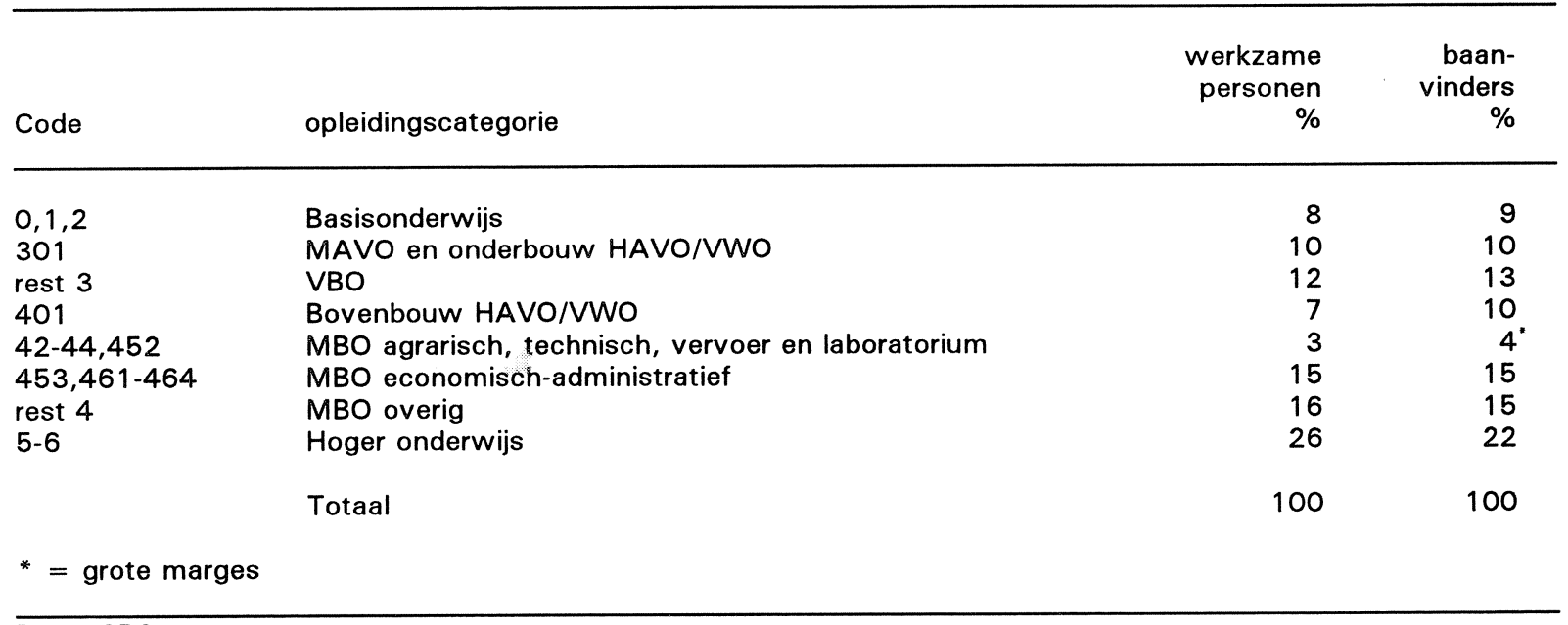


Als laatste wordt ingegaan op de verschillen in de beroepenstructuur van arbeidskrachten met een bepaalde opleidingsachtergrond (zie daarvoor de tabellen B.3, B.4 en B.5 van bijlage B). Daarbij moet worden opgemerkt dat op dit punt de informatie over de werkzame personen nauwelijks vergelijkbaar is met de beroepenstructuur per opleidingscategorie bij de inkomende en uitgaande pendel en de baanvinders. Dit wordt veroorzaakt doordat de informatie voor de werkzame personen op een lager aggregatieniveau beschikbaar is dan de informatie voor de pendelstromen en de baanvinders. Bij het aggregeren van de informatie over de werkzame personen naar het aggregatieniveau van de informatie over de pendel en de baanvinders, zal een vertekening plaatsvinden als gevolg van het feit dat verschillende cellen op het lagere aggregatieniveau geen informatie bevatten, omdat het aantal werkzame personen onder de vereiste ondergrens voor publikatie ligt. Bovendien moet worden bedacht dat er ook in het algemeen slechts in beperkte mate betrouwbare informatie beschikbaar is omtrent de beroepenstructuur per opleidingscategorie voor de vier onderscheiden groepen, omdat het bij veel van de cellen om minder dan 5.000 personen gaat.

Dit alles betekent dat alleen voor het 'MBO economisch-administratief' (453,461-464) een vergelijking zou kunnen worden gemaakt tussen de beroepenstructuur van de werkzame personen, de pendelstromen en de baanvinders. Van de werkzame personen met deze opleidingsachtergrond is ongeveer $50 \%$ werkzaam in de 'Lagere en middelbare administratieve beroepen' (611-612) ${ }^{28}$. Hetzelfde geldt voor de inkomende pendel, terwijl de uitgaande pendel beduidend lager is. Het percentage baanvinders werkzaam in deze beroepssector met een economisch-administratieve opleiding op MBO-niveau (453,461-464) bedraagt $63 \%$.

Voor de andere beroepengegevens per opleidingscategorie kan slechts een vergelijking worden gemaakt tussen de werkgelegenheidsstructuur van de forensenstromen en de baanvinders. Zowel voor de MAVO-ers als voor de HAVO/VWO-ers (301 en 401) geldt dat het percentage van de pendelaars dat in de 'Lagere en middelbare administratieve beroepen' (611-612) werkzaam is, hoger is dan het percentage baanvinders dat in deze beroepen werkt. Het omgekeerde geldt voor de hoger opgeleiden (5-6). Zoals in hoofdstuk 4 reeds is opgemerkt, is het percentage hoger opgeleide baanvinders dat werkzaam is in de 'Lagere en middelbare administratieve beroepen' (611-612) relatief hoog. Ten opzichte van de baanvinders zijn de hoger opgeleiden (5-6) relatief sterk vertegenwoordigd in de forensenstromen bij de 'Pedagogische, culturele en sociaal-culturele beroepen' $(0,1,7)$.

28. Doordat voor een aantal beroepssegmenten binnen deze beroepssector geen informatie voorhanden is omtrent het aantal werkzame personen, is hier sprake van een onderschatting. 


\section{BESLUIT}

In dit hoofdstuk wordt een aantal voorstellen gedaan voor indelingen naar sector, beroep en opleiding ten behoeve van de toekomstige dataverzameling. Daarvoor zou een viertal criteria als leidraad kunnen dienen:

1. Arbeidsmarktcriterium.

2. Vergelijkbaarheidscriterium.

3. Betrouwbaarheidscriterium.

4. Celvullingscriterium.

Het arbeidsmarktcriterium houdt in dat bij het opstellen van sector-, beroepen- en opleidingenindelingen rekening dient te worden gehouden met de bestaande segmenten op de arbeidsmarkt. Indien de beschikbare data en de betrouwbaarheid van deze data vereisen dat er categorieën worden samengevoegd, zullen alleen categorieën worden samengenomen waarbij er in enigermate sprake is van 'soortgelijke activiteiten'. Op basis van het vergelijkbaarheidscriterium wordt ervoor gezorgd dat de indelingen op de verschillende aggregatieniveaus steeds tot elkaar herleidbaar zijn. Dit betekent dat, een indeling op een lager aggregatieniveau eenduidig moet kunnen worden gerelateerd aan het hogere aggregatieniveau. Immers, het verdelen van een categorie die op een gedesaggregeerd niveau wordt onderscheiden over meerdere categorieën op een hoger aggregatieniveau maakt de onderlinge vergelijkbaarheid van de gegevens onmogelijk.

Bij het samenstellen van arbeidsmarktinformatie is het van belang om zoveel mogelijk betrouwbare gegevens te verkrijgen. Op basis van het betrouwbaarheidscriterium gaan wij ervan uit, dat er sprake is van redelijk betrouwbare informatie bij minimaal 5.000 personen in een cel $^{29}$. Het is echter onmogelijk om gedetailleerde arbeidsmarktinformatie te verschaffen, waarbij in alle relevante cellen tenminste 5.000 personen aanwezig zijn. Derhalve wordt het celvullingscriterium geoperationaliseerd door het formuleren van de randvoorwaarde, dat van tenminste $90 \%$ van het totaal aantal personen, waarop de desbetreffende tabel betrekking heeft, bekend moet zijn in welke cel zij zich bevinden.

Achtereenvolgens zullen in dit hoofdstuk de sector-, beroepen en opleidingenindelingen aan de orde komen op basis waarvan de benodigde informatie over de verschillende aspecten van de arbeidsmarkt in de toekomst zouden kunnen worden gegenereerd ${ }^{30}$. Daarbij zal telkens een tweetal indelingen worden voorgesteld. In eerste instantie wordt steeds nagegaan welke indeling kan worden gehanteerd voor het genereren van arbeidsmarktinformatie van de werkzame personen voor de hele provincie Noord-Holland verbijzonderd naar sector, beroep en

29. Bij $70 \%$-betrouwbaarheidsmarges van de steekproeffouten van de EBB, bedraagt de marge bij 5.000 personen in een cel ongeveer 400 , dat wil zeggen minder dan $10 \%$.

30. Daarbij moet overigens worden opgemerkt dat voor de hier voorgestelde indelingen slechts gebruik kan worden gemaakt van de in het kader van dit project verzamelde data. In hoeverre de toekomstige, op basis van de voorgestelde indelingen, verzamelde informatie zal voldoen aan het betrouwbaarheids- en het celvullingscriterium, kan derhalve nog niet worden nagegaan. 
opleiding. Aangezien er hierbij geen verdere verbijzondering van de gegevens plaatsvindt, kan bij het presenteren van deze informatie gebruik worden gemaakt van vrij ver gedesaggregeerde indelingen.

Vervolgens wordt een voorstel gedaan voor de sector-, beroepen en opleidingenindeling bij het samenstellen van informatie met betrekking tot de pendelstromen en de baanvinders. Aangezien het hierbij om kleinere aantallen werkzame personen gaat, zullen de indelingen hier betrekking hebben op een hoger aggregatieniveau. Om een goede vergelijking tussen de werkgelegenheidsstructuur van de werkzame personen, de inkomende en uitgaande pendel en de baanvinders te mogelijk te maken, moet voor al deze drie invalshoeken de desbetreffende arbeidsmarktinformatie op dit hogere aggregatieniveau worden gegenereerd ${ }^{31}$. Immers, als deze geaggregeerde informatie zou ontbreken, moet de gedesaggregeerde informatie met betrekking tot de totale werkzame personen worden gesommeerd, waardoor er afrondfouten ontstaan (zie hoofdstuk 4).

Ook is nog bekeken op basis van welke indelingen de sector-, beroepen- en opleidingenstructuur van de werkgelegenheid verbijzonderd naar RBA-gebied in beeld zouden kunnen worden gebracht. Gebleken is echter dat de indelingen die worden voorgesteld bij het genereren van arbeidsmarktinformatie voor de forensenstromen en de baanvinders ook geschikt zijn voor het genereren van naar RBA-gebied verbijzonderde informatie over de werkgelegenheidsstructuur van de werkzame personen. Opgemerkt moet worden dat voor GV op basis van in dit rapport gebruikte indeling slechts in beperkte mate informatie beschikbaar is. Door de in dit hoofdstuk voorgestelde indelingen zal de informatie over dit RBA-gebied kunnen toenemen. Het is echter niet bekend in welke orde de voorgestelde indelingen bijdragen tot meer informatie over GV.

\section{Sectorindeling}

Voor informatie over werkzame personen naar branche voor de hele provincie Noord-Holland kan gebruik worden gemaakt van de SBI-bedrijfsklassen (zie hiervoor tabel 6.1). Hierbij moet worden opgemerkt dat er in de in dit onderzoek onderscheiden bedrijfsklassen 'Kleding- en schoenenindustrie' (22-24) en 'Hout- en bouwmaterialenindustrie' $(25,32)$ in de periode 19891991 gemiddeld minder dan 5.000 personen werkzaam waren. Voor de bedrijfstak 'Delfstoffenwinning' en de bedrijfsklasse 'Aardolie- en steenkoolverwerking' is zelfs in het geheel geen informatie beschikbaar is de desbetreffende periode.

31. Overigens moet worden beseft dat het gebruik van meerdere indelingen zal leiden tot hogere kosten, daar in dat geval dezelfde soort tabellen op meerdere aggregatieniveaus moeten worden gegenereerd. 
Tabel 6.1. SBI-bedrijfsklassenindeling

\begin{tabular}{|c|c|}
\hline Code & naam \\
\hline 01 & Land- en tuinbouw \\
\hline 02 & Bosbouw \\
\hline 03 & Visserij \\
\hline 11 & Kolenmijnbouw \\
\hline 12 & Aardolie- en aardgaswinning en -exploitatie \\
\hline 19 & Overige delfstoffenwinning \\
\hline $20 / 21$ & Voedings- en genotmiddelenindustrie \\
\hline 22 & Textielindustrie \\
\hline 23 & Kledingindustrie \\
\hline 24 & Leder-, schoen- e.a. lederwarenindustrie (excl. kleding) \\
\hline 25 & Hout- en meubelindustrie (excl. metalen meubelen) \\
\hline 26 & Papier- en papierwarenindustrie \\
\hline 27 & Grafische industrie, uitgeverijen \\
\hline 28 & Aardolie-industrie \\
\hline 29 & Chemische industrie \\
\hline 30 & Kunstmatige en synthetische garen- en vezelindustrie \\
\hline 31 & Rubber- en kunstofverwerkende industrie \\
\hline 32 & Bouwmaterialen-, aardewerk en glasindustrie \\
\hline 33 & Basismetaalindustrie \\
\hline 34 & Metaalproduktie-industrie (excl. machines en transportmiddelen) \\
\hline 35 & Machine-industrie \\
\hline 36 & Elektrotechnische industrie \\
\hline 37 & Transportmiddelenindustrie \\
\hline 38 & Instrumenten- en optische industrie \\
\hline 39 & Overige industrie \\
\hline 40 & Openbare nutsbedrijven \\
\hline 51 & Bouwnijverheid \\
\hline 52 & Bouwinstallatiebedrijven \\
\hline $61-64$ & Groothandel \\
\hline $65-66$ & Detailhandel \\
\hline 67 & Hotels, restaurants, cafés e.d. \\
\hline 68 & Reparatiebedrijven voor gebruiksgoederen \\
\hline 71 & Spoorwegen \\
\hline 72 & Wegvervoer \\
\hline 73 & Zeevaart \\
\hline 74 & Binnenvaart \\
\hline 75 & Luchtvaart \\
\hline 76 & Hulpbedrijven vervoer \\
\hline 77 & Communicatiebedrijven \\
\hline 81 & Bankwezen \\
\hline 82 & Verzekeringswezen \\
\hline 83 & Exploitatie van en handel in onroerende goederen e.d. \\
\hline 84 & Zakelijke dienstverlening \\
\hline 85 & Verhuur van machines e.a. roerende goederen \\
\hline 90 & Openbaar bestuur, defensie en wettelijke sociale verzekering \\
\hline 91 & Religieuze organisaties e.d. \\
\hline 92 & Onderwijs \\
\hline 93 & Gezondheids- en veterinaire diensten \\
\hline 94 & Maatschappelijke dienstverlening \\
\hline 95 & Sociaal-culturele en culturele instellingen \\
\hline 96 & Sport en recreatie \\
\hline 97 & Bedrijfs- en werknemersorganisaties, researchinstellingen, overige sociale organisaties \\
\hline 98 & Overige dienstverlenende bedrijven \\
\hline 99 & Particuliere huishoudens met personeel in loondienst \\
\hline
\end{tabular}

In tabel 6.2 wordt de sectorindeling gepresenteerd die kan worden gehanteerd bij het genereren van informatie over de werkgelegenheidsstructuur van de pendelstromen en de baanvinders. Deze indeling komt grotendeels overeen met de ROA-sectorindeling (zie Berendsen, De Grip, Wieling en Willems, 1992a). Een tweetal ROA-sectoren is samengenomen, namelijk 'Hout- en bouwmaterialenindustrie' $(25,32)$ en 'Papier- en grafische industrie' $(26-27)$. Verder is in de 
ROA-sectoren 'Handel' (61-66), 'Vervoer en communicatie' (71-77) en 'Maatschappelijke dienstverlening' (91,94-97) een nadere detaillering aangebracht. In vergelijking met de indeling die in dit onderzoek is gebruikt voor het in beeld brengen van de werkgelegenheidsstructuur bij de baanvinders, geeft de hier voorgestelde indeling meer gedetailleerde arbeidsmarktinformatie. Met name voor de industrie, handel, vervoer en communicatie en de zakelijke en maatschappelijke dienstverlening is meer specifieke informatie beschikbaar. Ook voor de pendelstromen is op basis van deze indeling adequate informatie voorhanden voor de genoemde bedrijfstakken.

Tabel 6.2. Voorgestelde indeling voor bedrijfssectoren

\begin{tabular}{ll}
\hline Code & naam \\
\hline $01-03$ & Landbouw, visserij en bosbouw \\
$20-21$ & Voedings- en genotmiddelenindustrie \\
$22-24$ & Kleding- en schoenenindustrie \\
$25-27,32$ & Overige industrie \\
$29-31$ & Chemie \\
$33,34,35,38,39$ & Metaalindustrie \\
36 & Elektrotechnische industrie \\
37 & Transportmiddelenindustrie \\
$11-19,28,40$ & Energie \\
51,52 & Bouw \\
$61-64$ & Groothandel \\
$65-66$ & Detailhandel \\
67 & Horeca \\
$71-74$ & Weg- en watervervoer \\
75 & Luchtvaart \\
$76-77$ & Hulpbedrijven van het vervoer en communicatiebedrijven \\
$81-82$ & Banken en verzekeringen \\
$68,83-85,98,99$ & Overige commerciële dienstverlening \\
94 & Maatschappelijke dienstverlening \\
$91,95-97$ & Overige maatschappelijke dienstverlening \\
93 & Gezondheidszorg \\
90 & Openbaar bestuur, politie en defensie \\
92 & Onderwijs \\
\hline
\end{tabular}

Voor het in beeld brengen van de sectorale werkgelegenheidsstructuur verbijzonderd naar RBAgebied, kan worden opgemerkt, dat van $96 \%$ van de werkenden bekend is in welke sector en RBA-gebied men werkzaam is. Wel moet daarbij worden bedacht dat voor bijna twee derde deel van het totaal aantal cellen geen of minder betrouwbare informatie kan worden verschaft. Voor $33 \%$ van de cellen wordt geen informatie gegeven en $31 \%$ van de cellen bevat minder dan 5.000 werkenden. Om dit betrouwbaarheidsprobleem op te lossen, kan dezelfde indeling worden gehanteerd die in tabel 6.2 wordt voorgesteld voor het genereren van de sectorale werkgelegenheidsstructuur van de forensenstromen en de baanvinders.

\section{Beroepenindeling}

Voor informatie over werkzame personen naar beroep voor de hele provincie Noord-Holland kan gebruik worden gemaakt van de ROA-beroepsklassen. Hiermee kan op gedetailleerd niveau informatie over de beroepenstructuur van de werkgelegenheid worden verkregen. Aangenomen mag worden dat er op dit aggregatieniveau voldoende betrouwbare informatie beschikbaar zijn (zie Berendsen, De Grip, Wieling en Willems, 1992a). Er zal overigens wel enig informatieverlies 
optreden bij de technische beroepen. Het is vooralsnog niet geheel duidelijk hoe groot de dekkingsgraad zal zijn, indien van de ROA-beroepsklassen gebruik wordt gemaakt ${ }^{32}$.

Tabel 6.3. ROA-beroepsklassenindeling

\begin{tabular}{|c|c|}
\hline Code & naam \\
\hline 0131 & Leerkrachten basis- en speciaal onderwijs \\
\hline 0132 & Docenten voortgezet en hoger onderwijs \\
\hline 0133 & Schoolhoofden e.a. onderwijskundigen \\
\hline 0221 & Sportinstructeurs, officials, beroepssportlieden \\
\hline 1131 & Taal- en letterkundigen, vertalers, tolken \\
\hline 1231 & Pastorale beroepen \\
\hline 1321 & Fotografen, filmers, vormgevers en etaleurs \\
\hline 1331 & Beeldende en uitvoerde kunstenaars \\
\hline 2011 & Uitvoerend agrarisch personeel \\
\hline 2012 & Zelfstandige agrariërs \\
\hline 2031 & Landbouw(technische) ingenieurs \\
\hline 3011 & Heftruck- en hefvorkchauffeurs \\
\hline 3012 & Machinisten bouw en industrie \\
\hline 3021 & Leidinggevenden produktie, bedrijfskundigen en directeuren \\
\hline 3022 & Technische en medische vertegenwoordigers \\
\hline 3023 & Technische tekenaars \\
\hline 3024 & Technische analisten en amanuenses \\
\hline 3031 & Bèta-onderzoekers en technische vakspecialisten \\
\hline 3111 & Voedings- en genotmiddelenbereiders \\
\hline 3112 & Bakkers en (industrieel) bakkerijpersoneel \\
\hline 3211 & Produktiepersoneel textielindustrie \\
\hline 3212 & Stoffeerders, schoen- en lederwarenmakers \\
\hline 3213 & Kleding- e.a. textielproduktenmakers \\
\hline 3311 & Houtwaren-, papier- en kartonmakers \\
\hline 3312 & Timmerlieden e.a. houtbewerkers \\
\hline 3411 & Drukkers en produktiepersoneel grafische industrie \\
\hline 3511 & Produktiepersoneel chemische industrie \\
\hline 3611 & Delfstoffen(be)werkers, metaalvervaardigers \\
\hline 3612 & Machinale metaalbewerkers \\
\hline 3613 & Lassers en constructiewerkers \\
\hline 3614 & Machinebank-, plaatwerkers en gereedschapsmakers \\
\hline 3615 & Onderhoudsmonteurs, fietsen- en instrumentmakers \\
\hline 3621 & Automonteurs en (motor) rijwielherstellers \\
\hline 3622 & Middelbare (scheeps) werktuig(bouw) kundigen \\
\hline 3631 & Hogere werktuigbouwkundigen \\
\hline 3711 & Monteurs en controleurs van elektrotechnische produkten \\
\hline 3712 & Monteurs energievoorziening en elektriciteitsnetten \\
\hline 3721 & Elektriciens, elektro- en telecom(onderhouds)monteurs \\
\hline 3722 & Elektrotechnische opzichters en uitvoerders \\
\hline 3731 & Hogere elektrotechnici \\
\hline 3811 & Produktiepersoneel bouwmaterialen-, glas- en aardewerkindustrie \\
\hline 3911 & Metselaars, tegelzetters, straatmakers en stukadoors \\
\hline 3912 & Betonwerkers, dakdekkers, isoleerders en glaszetters \\
\hline 3913 & Huis- en constructieschilders \\
\hline 3914 & Loodgieters, pijpfitters en verwarmingsmonteurs \\
\hline 3915 & Gespecialiseerde bouwvak-, wegenbouw- en reinigingswerkers \\
\hline 3921 & Bouwkundige technici, opzichters en werkvoorbereiders \\
\hline 3931 & Architecten, geodeten e.a. hogere bouwkundigen \\
\hline
\end{tabular}

32. Op basis van de in tabel 2.3 gehanteerde indeling is van $99,7 \%$ van alle werkenden bekend in welk beroepssegment zij werkzaam zijn. Uit eerder onderzoek blijkt dat op basis van beroepsklassen in 1989 de dekkingsgraad $88 \%$ bedraagt (zie Berendsen, De Grip, Wieling en Willems, 1992b). Hierbij moet echter worden opgemerkt dat de ondergrens in dit laatstgenoemde onderzoek 5.000 personen bedroeg. Daar staat overigens wel tegenover dat bij het in beeld brengen van de aantallen werkzame personen geen ondergrens werd gesteld aan het gewerkte aantal uren per week. 
Tabel 6.3. ROA-beroepsklassenindeling (vervolg)

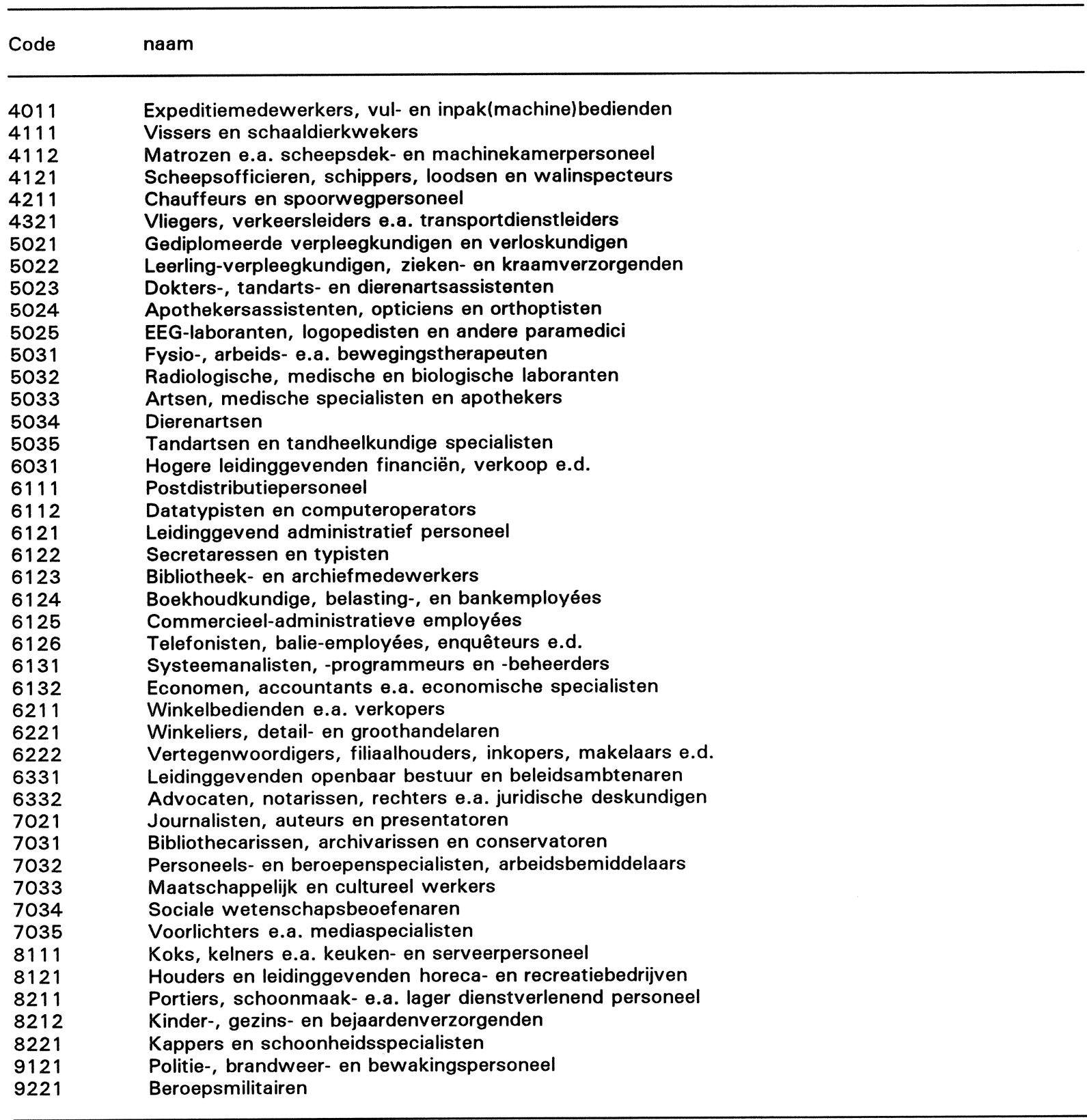

Voor het genereren van informatie over de werkgelegenheidsstructuur van de forensenstromen en de baanvinders naar beroep in de provincie Noord-Holland wordt voorgesteld de beroepssectorindeling te hanteren, zoals is aangegeven in tabel 6.4. Op basis van deze indeling kan meer gedetailleerde informatie over de werkgelegenheidsstructuur naar beroep voor baanvinders worden verkregen, dan op basis van de in dit rapport gehanteerde indeling. Met name de economisch-administratieve beroepen (6) kunnen verder worden uitgesplitst. Gezien de omvang van deze beroepen moet een dergelijke verbijzondering haalbaar zijn. Op grond van bestaande segmenten op de arbeidsmarkt zijn de 'Pedagogische beroepen' (0), de 'Culturele beroepen' (1), de 'Agrarische beroepen' (2), de 'Sociaal-culturele beroepen' (7), de 'Verzorgende en dienstverlenende beroepen' (8) en de 'Openbare orde- en veiligheidsberoepen' 
(9) afzonderlijk ingedeeld, dit in tegenstelling tot de indeling die in dit rapport bij de beroepeninformatie over baanvinders is gehanteerd (het arbeidsmarktcriterium). De informatie over de forensenstromen naar beroepssegment, zoals die in hoofdstuk 3 is gepresenteerd, heeft geleid tot een groot aantal cellen waarvoor geen of minder betrouwbare informatie kan worden verkregen. Om de beschikbaarheid en de betrouwbaarheid van de informatie over de pendelstromen naar beroep te vergroten, zal deze informatie op een hoger aggregatieniveau moeten worden samengesteld.

Tabel 6.4. Voorgestelde indeling voor beroepssectoren

\begin{tabular}{ll}
\hline Code & naam \\
\hline 0 & Pedagogische beroepen \\
1 & Culturele beroepen \\
2 & Agrarische beroepen \\
30 & Technische, ambachts- en industrieberoepen \\
$31-35$ & Overige technische beroepen \\
36 & Metaalberoepen \\
37 & Elektrotechnische beroepen \\
$38-39$ & Bouwmaterialen-, glas- en aardewerkberoepen, bouw- en installatieberoepen \\
4 & Transportberoepen \\
502 & Middelbare medische en paramedische beroepen \\
503 & Hogere medische en paramedische beroepen \\
611 & Lagere administratieve beroepen \\
6122 & Secretaressen, typisten \\
6124 & Boekhoudkundige, belasting-, loket- en bankemployées \\
6125 & Commercieel-administratieve employées \\
$6121,6123,6126$ & Overige middelbare administratieve beroepen \\
621 & Lagere commerciële beroepen \\
622 & Middelbare commerciële beroepen \\
$60,613,63$ & Hogere economisch-administratieve beroepen \\
7 & Sociaal-culturele beroepen \\
8 & Verzorgende en dienstverlenende beroepen \\
9 & Openbare orde- en veiligheidsberoepen \\
&
\end{tabular}

In hoofdstuk 2 is de beroepenstructuur van de werkgelegenheid van de werkzame personen verbijzonderd naar RBA-gebied besproken. Van $90 \%$ van de werkenden is bekend in welk beroep en RBA-gebied men werkzaam is. Wel moet daarbij worden bedacht dat voor drie kwart van het totaal aantal cellen geen of minder betrouwbare informatie kan worden verschaft. Voor $45 \%$ van de cellen wordt geen informatie gegeven en $30 \%$ van de cellen bevat minder dan 5.000 werkenden. Door dezelfde indeling te hanteren die in tabel 6.4 wordt voorgesteld, kan aan het betrouwbaarheidscriterium worden voldaan. Bovendien is de informatie hierdoor direct vergelijkbaar met de informatie over de pendelstromen en de baanvinders en blijven tevens de kosten beperkt.

Er moet wel worden opgemerkt dat het CBS met ingang van dit jaar een nieuwe beroepenindeling gaat hanteren (zie CBS, 1993b). In deze nieuwe Standaard Beroepenclassificatie 1992 (SBC'92) zijn de bekwaamheden die nodig om een bepaald takenpakket uit te voeren als uitgangspunt genomen. Dit wordt geïndiceerd door de 'meest geëigende opleiding'. Daarnaast worden verschillende soorten werkzaamheden onderscheiden die binnen een bepaald takenpakket worden verricht. Beroepen worden derhalve ingedeeld op basis van het niveau, de 
hoofdrichting en de richting van de bekwaamheden en de 'werksoorten'. In totaal worden dan 1.211 beroepen onderscheiden in de $\mathrm{SBC}^{\prime} 92$. In deze nieuwe beroepenindeling worden, op basis van het combineren van niveau, hoofdrichting en richting, 121 zogenaamde beroepsgroepen onderscheiden. Deze beroepsgroepen zij zo samengesteld dat er kan worden gesproken van betrouwbare waarnemingen bij een onderzoek met een steekproef van ongeveer 100.000 personen uit de populatie van 15 jaar en ouder. Daarbij is de ondergrens voor de omvang van een beroepsgroep gesteld op 5.000 beroepsbeoefenaren in de populatie, hetgeen tevens de ondergrens is bij het publiceren van jaarcijfers uit de EBB. Door het combineren van niveau en hoofdrichting ontstaan de 43 nieuwe beroepsklassen. Hierbij is er sprake van redelijke betrouwbare gegevens in onderzoeken met ongeveer 10.000 personen uit de populatie van 15 jaar en ouder. Deze nieuwe CBS-beroepsklassen zouden het uitgangspunt kunnen vormen voor in de toekomst te genereren arbeidsmarktinformatie naar beroep voor de provincie NoordHolland.

\section{Opleidingenindeling}

Bij het opstellen van informatie over werkzame personen naar opleiding voor de hele provincie Noord-Holland kan gebruik worden gemaakt van de ROA-opleidingstypen. Hiermee kan op een vrij gedesaggregeerd niveau informatie over de opleidingenstructuur van de werkgelegenheid worden verkregen (zie Berendsen, De Grip, Wieling en Willems, 1992a). Het is vooralsnog niet geheel duidelijk hoe groot de dekkingsgraad zal zijn, indien van de ROA-opleidingstypen wordt gehanteerd ${ }^{33}$.

Met betrekking tot de werkgelegenheidsstructuur naar opleiding voor zowel de inkomende en uitgaande pendel als de baanvinders, wordt de opleidingenindeling in tabel 6.6 voorgesteld. In vergelijking met in de hoofdstuk 4 gehanteerde indeling kan op basis van de hier voorgestelde indeling meer gedetailleerde informatie over de werkgelegenheidsstructuur naar opleiding voor baanvinders worden verkregen. Met name binnen het VBO en het hoger onderwijs vindt een nadere verbijzondering naar opleidingsrichting plaats. Bovendien wordt op MBO-niveau informatie verkregen over de medische, sociaal-culturele en verzorgende en politie en defensie opleidingen. Gezien de omvang van deze opleidingscategorieën moet een dergelijke verbijzondering haalbaar zijn. De in hoofdstuk 3 gepresenteerde informatie over de forensenstromen naar opleidingstype, geeft voor een groot aantal cellen geen of minder betrouwbare informatie. Teneinde de betrouwbaarheid van deze informatie te vergroten, moet deze informatie over forensenstromen naar opleiding derhalve op een hoger aggregatieniveau worden samengesteld.

33. Op basis van de in tabel 2.6 gehanteerde indeling is van $99,4 \%$ van alle werkenden bekend welk opleidingstype zij hebben voltooid. 
Tabel 6.5. ROA-opleidingstypenindeling

\begin{tabular}{|c|c|}
\hline Code & naam \\
\hline $000,111,201$ & Basisonderwijs \\
\hline 301 & MAVO en onderbouw HAVO/VWO \\
\hline $321-329$ & VBO agrarisch \\
\hline $331-339$ & VBO technisch \\
\hline $341-349$ & VBO haven en vervoer \\
\hline $361-369$ & VBO economisch-administratief \\
\hline $381-389$ & VBO verzorgend \\
\hline $391-394$ & VBO beveiliging en bewaking \\
\hline 401 & Bovenbouw HAVO/VWO \\
\hline $421-429$ & MBO agrarisch \\
\hline 431 & MBO technisch laboratorium \\
\hline $436-439$ & MBO technisch \\
\hline $441-449$ & MBO haven en vervoer. \\
\hline 452 & MBO medisch laboratorium \\
\hline 451,454 & MBO verpleging en ziekenverzorging \\
\hline $453,461-464$ & MBO economisch-administratief \\
\hline 466 & MBO bestuurlijk \\
\hline 471 & MBO sociaal-cultureel \\
\hline $481,484,486$ & MBO verzorgend \\
\hline 483 & MBO horeca en kappers \\
\hline $491-494$ & MBO politie en defensie \\
\hline 506 & HBO onderwijs \\
\hline 511 & HBO tolk en vertaler \\
\hline 516 & HBO theologisch \\
\hline $521-529$ & $\mathrm{HBO}$ agrarisch \\
\hline 531 & HBO technisch laboratorium \\
\hline $536-539$ & HBO technisch \\
\hline $541-549$ & HBO vervoer \\
\hline 552 & HBO medisch laboratorium \\
\hline 551,554 & HBO verpleging en paramedisch \\
\hline 561 & HBO economisch-administratief \\
\hline 562 & HBO technische bedrijfskunde \\
\hline 566 & HBO bestuurlijk \\
\hline 571 & HBO sociaal-cultureel \\
\hline 583 & HBO horeca \\
\hline 586 & HBO kunst \\
\hline $591-594$ & HBO politie en defensie \\
\hline 606 & WO onderwijs \\
\hline 611 & WO humaniora \\
\hline 616 & WO theologisch \\
\hline $621-623,629$ & WO agrarisch \\
\hline 631 & WO wis- en natuurkunde \\
\hline $636-639$ & WO technisch \\
\hline 651 & WO dier-, genees- en tandheelkunde \\
\hline 652 & WO medisch laboratorium \\
\hline $661-662$ & WO econom(etr)ie en bedrijfskunde \\
\hline 666 & WO rechten en bestuurskunde \\
\hline 671 & WO sociaal-cultureel \\
\hline 686 & WO kunst \\
\hline
\end{tabular}

Van $96 \%$ van de werkenden is bekend welke opleiding men heeft voltooid en in welk RBAgebied men werkzaam is. Wel moet daarbij worden bedacht dat voor bijna $60 \%$ van het totaal aantal cellen geen of minder betrouwbare informatie kan worden verschaft. Voor $41 \%$ van de cellen wordt geen informatie gegeven en $18 \%$ van de cellen bevat minder dan 5.000 werkenden. De in tabel 6.6 voorgestelde opleidingenindeling zorgt voor meer betrouwbare informatie. Dit heeft tevens als voordeel dat de informatie beter vergelijkbaar is en bovendien heeft dit een gunstige invloed op de kosten voor het genereren van de informatie. 
Tabel 6.6. Voorgestelde indeling voor opleidingscategorieën

Code naam

\section{$0,1,2$}

301

$321-329,331-339,341-349$

$361-369,381-389$

401

$421-429,431,436-439,441-449$

$453,461-464,466$

$451,452,454$

$471,481,483,484,486$

$491-494$

5,6 Verzorgend

5,6 Technisch

5,6 Economisch
Basisonderwijs

MAVO en onderbouw HAVO/VWO

VBO agrarisch, technisch en vervoer

VBO economisch-administratief en verzorgend

Bovenbouw HAVO/VWO

$M B O$ agrarisch, technisch en vervoer

MBO economisch-administratief

MBO medisch

MBO sociaal-cultureel en verzorgend

MBO politie en defensie

Hoger onderwijs verzorgend

Hoger onderwijs technisch

Hoger onderwijs economisch 


\section{LITERATUUR}

Berendsen, H., A. de Grip, M.H. Wieling, E.J.T.A. Willems (1992a), Arbeidsmarktinformatie naar opleiding en beroep voor de provincie Noord-Holland, ROA-R-1992/3, Maastricht.

Berendsen, H., A. de Grip, M.H. Wieling, E.J.T.A. Willems (1992b), Regionale arbeidsmarktinformatie naar opleiding en beroep, ROA-R-1992/2, Maastricht.

Bierings, H.B.A., F.A.G. Windmeijer (1992), Baanvinders en mobiliteit tussen RBA-gebieden, Supplement bij Sociaal-Economische Maandstatistiek, jrg. 1992, nr. 5, blz. 42-56.

CBS (1990), Enquête beroepsbevolking 1989, Voorburg/Heerlen.

CBS (1991), Enquête beroepsbevolking 1990, Voorburg/Heerlen.

CBS (1992), Enquête beroepsbevolking 1991, Voorburg/Heerlen.

CBS (1993a), Enquête beroepsbevolking 1992, Voorburg/Heerlen.

CBS (1993b), Standaard beroepenclassificatie 1992, SDU-Uitgeverij, 's-Gravenhage.

CPB (1992), Nederland in drievoud; een scenariostudie van de Nederlandse economie 19902015, SDU-Uitgeverij, 's-Gravenhage.

Grip, A. de, J.A.M. Heijke (1993), De aansluiting onderwijs-arbeidsmarkt: regionale arbeidsmarktinformatie, in: Werkgroep Ruimtelijke Arbeidsmarkt, Onderwijs en Arbeidsmarkt in de Regio, Eburon, Delft.

Grip, A. de, J.A.M. Heijke, E.J.T.A. Willems (1992), Scholing en mobiliteit, Maandschrift Economie, vol. 56, p. 131-144.

Hoevenberg J., E.J.T.A. Willems, A. de Grip (1993), Actuele arbeidsmarktinformatie voor de regio Rijnmond, ROA-R-1993/5.

Loo, P.J.E van de, R.J.P. Dekker, A. de Grip (1992), Arbeidsmarktsegmentatie als uitgangspunt voor een beroepenclassificatie, Tijdschrift voor Arbeidsvraagstukken, jrg. 8, nr.1, blz. 19-31.

Mourik, A. van, J.J. Siegers (1988), Ontwikkelingen in de beroepssegregatie tussen mannen en vrouwen 1971-1985, Economische Statistische Berichten, jrg. 73, nr. 3668, blz. 732-737.

Ministerie van Sociale Zaken en Werkgelegenheid (1990), Rapportage Arbeidsmarkt 1990, 'sGravenhage.

ROA (1992), De arbeidsmarkt naar opleiding en beroep tot 1994, ROA-R-1992/1, Maastricht.

ROA (1993), Statistische bijlage: de arbeidsmarkt naar opleiding en beroep tot 1998, ROA-R1993/10B, Maastricht.

Siegers, J.J. (1979), Beroepssegregatie tussen mannen en vrouwen in Nederland, Economische Statistische Berichten, jrg. 64, nr. 3194, blz. 208-213. 
BIJLAGE A: GEHANTEERDE SECTOR-, BEROEPEN- EN OPLEIDINGENINDELINGEN 


\section{Bedrijfsklasse}

Code nam

0

1

20-21

22-24

25,32

26,27

28

29-31

33

34

35

36

37

38,39

40

5

$61-64$

65-66

67

68

71-74

75

76-77

81

82

$83-85$

90

92

93

94

95

96

91,97

98
Landbouw, visserij en bosbouw

Delfstoffenwinning

Voedings- en genotmiddelenindustrie

Kleding- en schoenenindustrie

Hout- en bouwmaterialenindustrie

Papier- en grafische industrie

Aardolie- en steenkoolverwerking

Chemie

Basismetaalindustrie

Metaalprodukten (excl. machines e.d)

Machine-industrie

Elektrotechnische industrie

Transportmiddelenindustrie

Instrumenten-, optische en overige industrie

Openbare nutsbedrijven

Bouwnijverheid en -installatiebedrijven

Groothandel

Detailhandel

Hotels, restaurants, cafés e.d.

Reparatiebedrijven voor gebruiksgoederen

Weg- en watervervoer

Luchtvaart

Hulpbedrijven van het vervoer en communicatiebedrijven

Bankwezen

Verzekeringswezen

Handel onroerend goed, zakelijke dienstverlening en verhuur roerende goederen

Openbaar bestuur, defensie, wettelijke sociale verzekering

Onderwijs

Gezondheids- en veterinaire diensten

Maatschappelijke dienstverlening

Sociaal-culturele en culturele instellingen

Sport en recreatie

Religieuze en overige sociale organisaties

Overige dienstverlenende bedrijven 
Code naam

01-03

20-21

22-24

$25-27,32$

29-31

33-39

$11-19,28,40$

$51,52,83$

61-66

$71-77$

$67,68,81,82,84,85,98,99$

$91,94-97,929$

93

90,92 excl. 929
Landbouw, visserij en bosbouw

Voedings- en genotmiddelenindustrie

Kleding- en schoenenindustrie

Overige industrie

Chemie

Metaal-, elektrotechnische, transportmiddelenindustrie

Delfstoffen en rest nijverheid

Bouw en woningbezit

Handel

Vervoer en communicatie

Andere tertiaire diensten

Andere kwartaire diensten

Gezondheids- en veterinaire diensten

Openbaar bestuur, defensie, wettelijke sociale verzekering en onderwijs 
$-70-$

\section{Bedrijfstak}

Code naam

0

4

5

7

9
Landbouw, visserij en bosbouw

Delfstoffenwinning

Industrie

Openbare nutsbedrijven

Bouwnijverheid en -installatiebedrijven

Handel, hotel- en restaurantwezen, reparatiebedrijven voor gebruiksgoederen

Vervoer en communicatie

Bank en verzekering, zakelijke dienstverlening

Overige dienstverlening 


Code naam

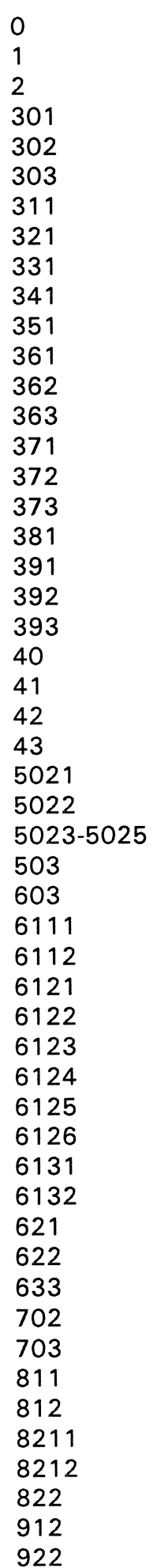

Pedagogische beroepen

Culturele beroepen

Agrarische beroepen

Lagere technische, ambachts- en industrieberoepen

Middelbare technische, ambachts- en industrieberoepen

Hogere technische, ambachts- en industrieberoepen

Lagere voedings- en genotmiddelenberoepen

Lagere textielberoepen

Lagere hout- en papierberoepen

Lagere grafische beroepen

Lagere chemische beroepen

Lagere metaalberoepen

Middelbare metaalberoepen

Hogere metaalberoepen

Lagere elektrotechnische beroepen

Middelbare elektrotechnische beroepen

Hogere elektrotechnische beroepen

Lagere bouwmaterialen-, glas- en aardewerkberoepen

Lagere bouw- en installatieberoepen

Middelbare bouw- en installatieberoepen

Hogere bouw- en installatieberoepen

Transportberoepen

Maritieme e.a. waterwegtransportberoepen

Rail- en wegtransportberoepen

Lucht- en overige transportberoepen

Gediplomeerde verpleegkundigen, verloskundigen

Leerling-verpleegkundigen, zieken- en kraamverzorgenden

Dokters-, tandarts-, apothekersassistenten en andere paramedici

Hogere medische en paramedische beroepen

Hogere economisch-administratieve beroepen

Postdistributiepersoneel

Datatypisten, computeroperators

Leidinggevend administratief personeel

Secretaressen, typisten

Bibliotheek- en archiefmedewerkers

Boekhoudkundige, belasting- en bankemployées

Commercieel-administratieve employées

Telefonisten, balie-employées, enquêteurs e.d.

Systeemanalisten, -programmeurs en -beheerders

Economen, accountants, e.a. economische specialisten

Lagere commerciële beroepen

Middelbare commerciële beroepen

Hogere bestuurlijke en juridische beroepen

Middelbare sociaal-culturele beroepen

Hogere sociaal-culturele beroepen

Lagere horecaberoepen

Middelbare horecaberoepen

Portiers, schoonmaak- e.a. lager dienstverlenend personeel

Kinder-, gezins-, bejaardenverzorgenden

Middelbare verzorgende beroepen

Middelbare politie-, brandweer- en bewakingsberoepen

Middelbare militaire beroepen 


\section{Beroepssector}

Code naam

$0,1,7$

30

$2,31-35$

$36-39$

4

5

611-612

62

$60,613,63$

8,9
Pedagogische, culturele en sociaal-culturele beroepen

Technische, ambachts- en industrieberoepen

Agrarische, voedings- en genotmiddelen-, textiel-, hout- en papier-, grafische, chemische beroepen

Metaal-, elektrotechnische, bouwmaterialen-, glas- en aardewerkberoepen

Transportberoepen

Medische en paramedische beroepen

Lagere en middelbare administratieve beroepen

Commerciële beroepen

Hogere economisch-administratieve beroepen

Verzorgende en dienstverlenende beroepen en openbare orde- en veiligheidsberoepen 
Opleidingstype

Code naam

$0,1,2$

301

321-329

331-339

341-349

361-369

381-389

391-394

401

421-429

431

436-439

441-449

452

453,461-464

451,454

466

471

$481,484,486$

483

491-494

5,6 Algemeen

5,6 Verzorgend

5,6 Technisch

5,6 Economisch

5,6 Overig
Basisonderwijs

MAVO en onderbouw HAVO/VWO

VBO agrarisch

VBO technisch

VBO haven en vervoer

VBO economisch-administratief

VBO verzorgend

VBO beveiliging en bewaking

Bovenbouw HAVO/VWO

MBO agrarisch

MBO technisch laboratorium

MBO technisch

MBO haven en vervoer

MBO medisch laboratorium

MBO economisch-administratief

MBO verpleging en ziekenverzorging

MBO bestuurlijk

MBO sociaal-cultureel

$\mathrm{MBO}$ verzorgend

MBO horeca en kappers

MBO politie en defensie

Hoger onderwijs algemeen

Hoger onderwijs verzorgend

Hoger onderwijs technisch

Hoger onderwijs economisch

Hoger onderwijs overig 


\section{Opleidingscategorie}

Code naam

$0,1,2$

301

Basisonderwijs

rest 3

401

$42-44,452$

$453,461-464$

rest 4

MAVO en onderbouw HAVO/VWO

VBO

Bovenbouw HAVO/VWO

MBO agrarisch, technisch, vervoer en laboratorium

MBO economisch-administratief

MBO overig

5-6

Hoger onderwijs 
$-75-$

BIJLAGE B: AANVULLENDE TABELLEN 
Tabel B.1. Percentage werkenden naar bedrijfssector per beroepssegment, gemiddelde 1989-1991

aantal

0

91,94-97,929

90,92 ,excl. 929

1

$67,68,81,82,84,85,98,99$

$91,94-97,929$

2

01-03

90,92 ,excl. 929

302

20-21

25-27,32

29-31

33-39

$11-19,28,40$

$51,52,83$

61-66

71-77

$67,68,81,82,84,85,98,99$

$91,94-97,929$

90,92 ,excl. 929

311

20-21

61-66

321

22-24

331

25-27,32

$51,52,83$

341

$25-27,32$

351

29-31

361

33-39

61-66

71-77

$67,68,81,82,84,85,98,99$

362

$67,68,81,82,84,85,98,99$
Pedagogische beroepen

Andere kwartaire diensten

2.500

$6 *$

Openbaar bestuur, defensie, wettelijke

sociale verzekering en onderwijs

40.000

90

Culturele beroepen

Andere tertiaire diensten

4.500

$28^{*}$

Andere kwartaire diensten

7.500

47

Agrarische beroepen

Landbouw, visserij en bosbouw $\quad 20.000 \quad 76$

Openbaar bestuur, defensie, wettelijke

sociale verzekering en onderwijs

3.000

$11^{*}$

Middelbare technische, ambachts- en industrieberoepen

Voedings- en genotmiddelenindustrie

2.000

Overige industrie

3.000

Chemie

3.000

Metaal-, elektrotechnische,

transportmiddelenindustrie

10.000

2.000

Delfstoffen en rest nijverheid

5.000

Handel

Vervoer en communicatie

4.000

4.500

Andere tertiaire diensten

10.500

3.500

Openbaar bestuur, defensie, wettelijke

sociale verzekering en onderwijs

4.000

4 4

6"

$6^{*}$

19

$4 *$

9

$8^{*}$

$9^{*}$

20

$8^{*}$

Lagere voedings- en genotmiddelenberoepen

Voedings- en genotmiddelenindustrie

6.000

67

Handel

2.500

$28^{*}$

Lagere textielberoepen

Kleding- en schoenenindustrie

2.500

$46^{*}$

Lagere hout- en papierberoepen

Overige industrie

2.000

5.000

$20 *$

Bouw en woningbezit

50

Lagere grafische beroepen

Overige industrie

9.000

86

Lagere chemische beroepen

Chemie

2.000

$57^{*}$

Lagere metaalberoepen

Metaal-, elektrotechnische,

transportmiddelenindustrie

18.000

2.500

Handel

3.500

Vervoer en communicatie

2.000

55

$8 *$

Andere tertiaire diensten

4.500

$60^{*}$

Middelbare metaalberoepen

Andere tertiaire diensten

$6^{*}$ 
372

33-39

$51,52,83$

61-66

71-77

391

$51,52,83$

$67,68,81,82,83,84,85,98,99$

90,92 ,excl. 929

40

33-39

61-66

71-77

$67,68,81,82,84,85,98,99$

42

61-66

$71-77$

43

71-77

5021

$91,94-97,929$

93

5022

$91,94-97,929$

93

5023-5025

61-66

93

503

93

603

61-66

$67,68,81,82,84,85,98,99$

$91,94-97,929$

6111

71-77

6122

61-66

$67,68,81,82,84,85,98,99$

$91,94-97-929$

93

90,92, excl. 929
Middelbare elektrotechnische beroepen

Metaal-, elektrotechnische,

transportmiddelenindustrie

$3.50025^{*}$

Bouw en woningbezit

2.000

2.000

$14^{*}$

Handel

2.500

$14^{*}$

Vervoer en communicatie

$18 *$

Lagere bouw- en installatieberoepen

Bouw en woningbezit

$7.500 \quad 50$

Andere tertiaire diensten

2.000

$13^{*}$

Openbaar bestuur, defensie, wettelijke

sociale verzekering en onderwijs

$2.000-13^{*}$

Transportberoepen

Metaal-, elektrotechnische,

transportmiddelenindustrie

Handel

3.000

7.000

3.000

2.000

Vervoer en communicatie

35

Andere tertiaire diensten

$10^{*}$

Rail- en wegtransportberoepen

Handel

3.000

$15^{*}$

Vervoer en communicatie

12.500

61

Lucht- en overige transportberoepen

Vervoer en communicatie

4.500

$64^{*}$

Gediplomeerde verpleegkundigen, verloskundigen

Andere kwartaire diensten 2.500

18.500

$11^{*}$

84

Leerling-verpleegkundigen, zieken- en kraamverzorgenden

Andere kwartaire diensten $\quad 5.500$

38

Gezondheids- en veterinaire diensten

9.000

62

Dokters-, tandarts-, apothekersassistenten en andere paramedici

Handel

$2.000 \quad 22$

Gezondheids- en veterinaire diensten

6.500

72

Hogere medische en paramedische beroepen

Gezondheids- en veterinaire diensten

16.500

83

Hogere economisch-administratieve beroepen

Handel

$2.000 \quad 13^{*}$

Andere tertiaire diensten

3.000

2.000

$19^{*}$

Andere kwartaire diensten

$13^{*}$

Postdistributiepersoneel

Vervoer en communicatie

6.000

75

Secretaressen, typisten

Handel

4.000

$14^{*}$

Andere tertiaire diensten

95.000

32

Andere kwartaire diensten

3.000

3.000

10

Gezondheids- en veterinaire diensten

$10^{*}$

Openbaar bestuur, defensie, wettelijke

sociale verzekering en onderwijs

4.000

$14^{*}$ 
6124

33-39

$51,52,83$

61-66

71-77

$67,68,81,82,84,85,98,99$

$91,94-97,929$

90,92 ,excl. 929

\section{5}

25-27,32

33-39

$51,52,83$

61-66

71-77

$67,68,81,82,84,85,98,99$

$91,94-97,929$

93

90,92,excl. 929

6126

$71-77$

$67,68,81,82,84,85,98,99$

6131

33-39

61-66

$71-77$

$67,68,81,82,84,85,98,99$

90,92, excl. 929

6132

$67,68,81,82,84,85,98,99$

621

61-66

622

61-66

$67,68,81,82,84,85,98,99$

633

$67,68,81,82,84,85,98,99$

90,92, excl. 929

702

$25-27,32$

703

$67,68,81,82,84,85,98,99$

$91,94-97,929$

93

90,92, excl. 929
Boekhoudkundige, belasting- en bankemployées Metaal-, elektrotechnische, transportmiddelenindustrie

Bouw en woningbezit

2.500

3.000

Handel

Vervoer en communicatie

11.500

4.500

Andere tertiaire diensten

Andere kwartaire diensten

Openbaar bestuur defensie, wettelijke

sociale verzekering en onderwijs

30.000

2.5004 .

$7.000 \quad 10$

Commercieel-administratieve employées

Overige industrie

Metaal-, elektrotechnische,

transportmiddelenindustrie

Bouw en woningbezit

Handel

Vervoer en communicatie

Andere tertiaire diensten

Andere kwartaire diensten

Gezondheids- en veterinaire diensten

Openbaar bestuur, defensie wettelijke

sociale verzekering en onderwijs

$4^{*}$

17

$7^{*}$

45

3*

$\begin{array}{ll}3.000 & 5^{*} \\ 2.500 & 4^{*}\end{array}$

$\begin{array}{ll}2.500 & 4 \\ 0.500 & 17\end{array}$

$8.000 \quad 13$

$12.500 \quad 21$

$\begin{array}{ll}2.500 & 4 \\ & 4\end{array}$

22

Telefonisten,balie-employées, enquêteurs, e.d.

Vervoer en communicatie

$28^{*}$

Andere tertiaire diensten

Systeemanalisten, -programmeurs en beheerder;

Metaal-, elektrotechnische,

transportmiddelenindustrie

Handel

Vervoer en communicatie

2.000

4.000

2.000

6.500

Andere tertiaire diensten

33

Openbaar bestuur, defensie, wettelijke

sociale verzekering en onderwijs

$3.000 \quad 15$

Economen, accountants e.a. economisch speciallisten

Andere tertiaire diensten

$50 *$

Lagere commerciële beroepen

Handel

$=3.500 \quad 86$

Middelbare commerciële beroepen

Handel

4.500

69

Andere tertiaire diensten

5.000

14

Hogere bestuurlijke en juridische beroepen

Andere tertiaire diensten

$3.000 \quad 35^{\prime \prime}$

Openbaar bestuur, wettelijk

sociale verzekering en onderwijs

$4.500 \quad 53$

Middelbare sociaal-culturele beroepen

Overige industrie

$36^{*}$

Hogere sociaal-culturele beroepen

Andere tertiaire diensten

$3.500 \quad 15^{*}$

Andere kwartaire diensten

0.000

42

Gezondheids- en veterinaire diensten

2.500

$10^{*}$

Openbaar bestuur, wettelijke

sociale verzekering en onderwijs 
811

$67,68,81,82,84,85,98,99$

$91,94-97,929$

93

812

$67,68,81,82,84,85,98,99$

8211

71-77

$67,68,81,82,84,85,98,99$

$91,94-97,929$

93

90,92 ,excl. 929

8212

91,94-97,929

822

$67,68,81,82,84,85,98,99$

912

$67,68,81,82,84,85,98,99$

90,92 ,excl. 929

922

90,92,excl. 929

* = grote marges
Lagere horecaberoepen

Andere tertiaire diensten

14.500

58

Andere kwartaire diensten

3.000

2.000

$12^{*}$

Gezondheids- en veterinaire diensten

7.500

75

Middelbare horecaberoepen

Andere tertiaire diensten

$13 *$

Vervoer en communicatie

3.500

41

Andere tertiaire diensten

11.500

$14^{*}$

Andere kwartaire diensten

4.000

2.500

3.500

$13^{*}$

sociale verzekering en onderwijs

13.500

84

Andere kwartaire diensten

5.000

100

Andere tertiaire diensten

Middelbare politie-brandweer- en bewakingsberoepen

Andere tertiaire diensten

2.000

$15^{*}$

Apenbaar bestuur, defensie, wettelijke

sociale verzekering en onderwijs

9.500

70

Middelbare militaire beroepen

Openbaar bestuur, defensie, wettelijke

sociale verzekering en onderwijs

5.500

100

Bron: CBS 
Tabel B.2. Percentage werkenden naar bedrijfssector per opleidingstype, gemiddelde 1990-1991

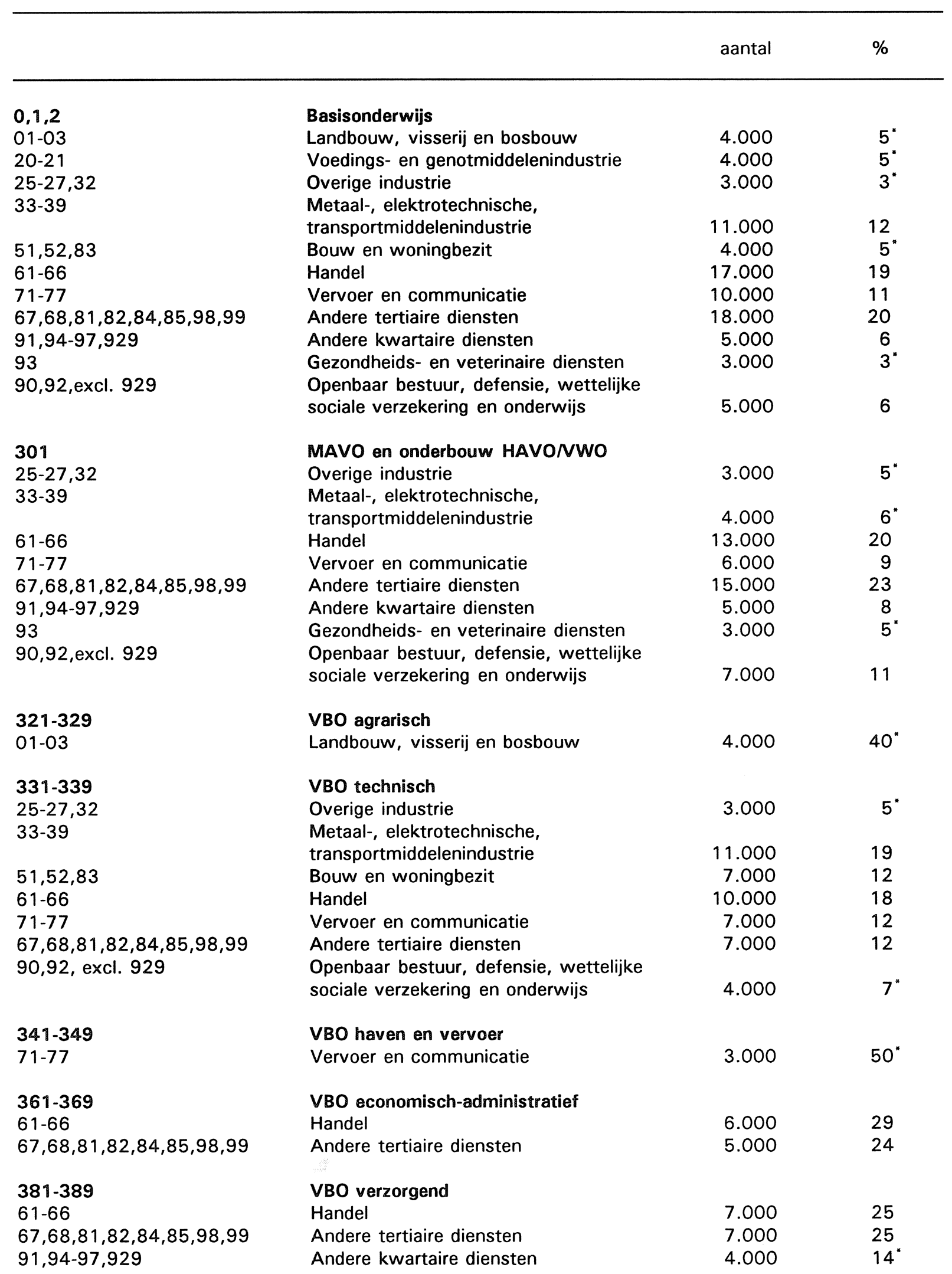


401

$25-27,32$

61-66

$71-77$

$67,68,81,82,84,85,98,99$

$91,94-97,929$

93

90,92 ,excl. 929

421-429

01-03

436-439

20-21

25-27,32

$11-19,28,40$

33-39

$51,52,83$

61-66

$71-77$

$67,68,81,82,84,85,98,99$

91,94-97,929

90,92 , excl. 929

441-449

71-77

453,461-464

$25-27,32$

33-39

$51,52,83$

61-66

71-77

$67,68,81,82,84,85,98,99$

$91,94-97,929$

93

90,92, excl. 929

451,454

$91,94-97,929$

93

466

90,92, excl. 929

471

90,92,excl. 929

$481,484,486$

61-66

$67,68,81,82,84,85,98,99$

$91,94-97,929$

93
Bovenbouw HAVONWO

Overige industrie

3.000

$5^{*}$

Handel

Vervoer en communicatie

9.000

16

$7.000 \quad 13$

Andere tertiaire diensten

18.000

32

Andere kwartaire diensten

6.000

11

Gezondheids- en veterinaire diensten

3.000

5.000

9

sociale verzekering en onderwijs

MBO agrarisch

Landbouw, visserij en bosbouw

5.000

46

MBO technisch

Voedings- en genotmiddelenindustrie

Overige industrie

Delfstoffen en rest nijverheid

3.000

7.000

3.000

$4^{*}$

Metaal-, elektrotechnische,

transportmiddelenindustrie

Bouw en woningbezit

$17.000 \quad 20$

$8.000 \quad 10$

$10.000 \quad 12$

$10.000 \quad 12$

$12.000 \quad 14$

3.000

7.000

8

Openbaar bestuur, defensie, wettelijke sociale verzekering en onderwijs

4.000

57

Vervoer en communicatie

3.000

$3^{*}$

Overige industrie

4.000

4.000

30.000

10.000

30.000

6.000

5.000

8.000

sociale verzekering en onderwijs

5.000

20.000

Andere kwartaire diensten

69

MBO bestuurlijk

Openbaar bestuur defensie, wettelijke sociale verzekering en onderwijs

4.000

$80^{*}$

MBO sociaal-cultureel

Openbaar bestuur defensie, wettelijke sociale verzekering en onderwijs

MBO verzorgend

Handel

4.000

$15^{*}$

Andere tertiaire diensten

6.000

22

Andere kwartaire diensten

9.000

33

Gezondheids- en veterinaire diensten 
483

$67,68,81,82,84,85,98,99$

491-494

90,92,excl. 929

5,6 verzorgend

25-27,32

61-66

$67,68,81,82,84,85,98,99$

$91,94-97,929$

93

90,92,excl. 929

\section{5,6 technisch}

$$
\text { 33-39 }
$$

71-77

$67,68,81,82,84,85,98,99$

$91,94-97,929$

90,92, excl. 929

5,6 economisch

33-39

61-66

71-77

$67,68,81,82,84,85,98,99$

$91,94-97,929$

90,92, excl. 929
MBO horeca en kappers

Andere tertiaire diensten

5.000

63

MBO politie en defensie

Openbaar bestuur, defensie, wettelijke sociale verzekering en onderwijs

10.000

67

Hoger onderwijs verzorgend

Overige industrie

3.000

5.000

13.000

24.000

28.000

43.000

36

sociale verzekering en onderwijs

Hoger onderwijs technisch

Metaal-, elektrotechnische,

transportmiddelenindustrie

Vervoer en communicatie

Andere tertiaire diensten

4.000

4.000

6.000

3.000

8.000

sociale verzekering en onderwijs

Hoger onderwijs economisch

Metaal-, elektrotechnische,

transportmiddelenindustrie

3.000

$6^{*}$

Handel

6.000

13

Vervoer en communicatie

Andere tertiaire diensten

Andere kwartaire diensten

4.000

19.000

40

Openbaar bestuur, defensie, wettelijke sociale verzekering en onderwijs
3.000

8.000

* = grote marges

Bron: CBS 
Tabel B.3. Percentage werkenden naar beroepssegment per opleidingstype, gemiddelde 1990-1991

aantal

\begin{tabular}{|c|c|c|c|}
\hline $0,1,2$ & Basisonderwijs & & \\
\hline 2 & Agrarische beroepen & 4.000 & $5^{*}$ \\
\hline 302 & Middelbare technische, ambachts- en industrieberoepen & 3.000 & $3^{*}$ \\
\hline 361 & Lagere metaalberoepen & 5.000 & 6 \\
\hline 391 & Lagere bouw-en installatieberoepen & 4.000 & $5^{*}$ \\
\hline 40 & Transportberoepen & 7.000 & 8 \\
\hline 42 & Rail-en wegtransportberoepen & 6.000 & 7 \\
\hline 6124 & Boekhoudkundige, belasting- en bankemployées & 3.000 & $3^{*}$ \\
\hline 6125 & Commercieel-administratieve employées & 4.000 & $5^{*}$ \\
\hline 621 & Lagere commerciële beroepen & 6.000 & 7 \\
\hline 811 & Lagere horecaberoepen & 6.000 & 7 \\
\hline 8211 & Portiers-, schoonmaak- e.a. lager dienstverlenend personeel & 10.000 & 11 \\
\hline 301 & MAVO en onderbouw HAVO/VWO & & \\
\hline 6122 & Secretaressen, typisten & 4.000 & $6^{*}$ \\
\hline 6124 & Boekhoudkundige, belasting- en bankemployées & 8.000 & 13 \\
\hline 6125 & Commercieel- administratieve employées & 9.000 & 14 \\
\hline 621 & Lagere commerciële beroepen & 5.000 & 8 \\
\hline 622 & Middelbare commerciële beroepen & 3.000 & $5^{*}$ \\
\hline 8211 & Portiers-, schoonmaak- e.a. lager dienstverlenend personeel & 3.000 & $5^{*}$ \\
\hline $321-329$ & VBO agrarisch & & \\
\hline 2 & Agrarische beroepen & 5.000 & 50 \\
\hline $331-339$ & VBO technisch & & \\
\hline 302 & Middelbare technische, ambachts- en industrieberoepen & 4.000 & 7" \\
\hline 331 & Lagere hout-en papierberoepen & 4.000 & $7^{*}$ \\
\hline 361 & Lagere metaalberoepen & 9.000 & 16 \\
\hline 372 & Middelbare elektrotechnische beroepen & 3.000 & $5 "$ \\
\hline 391 & Lagere bouw- en installatieberoepen & 4.000 & $7^{*}$ \\
\hline 40 & Transportberoepen & 3.000 & $5^{\prime \prime}$ \\
\hline 42 & Rail-en wegtransportberoepen & 3.000 & $5^{*}$ \\
\hline 6125 & Commercieel-administratieve employées & 3.000 & $5^{*}$ \\
\hline 621 & Lagere commerciële beroepen & 3.000 & $5^{*}$ \\
\hline 361-369 & VBO economisch administratief & & \\
\hline 6124 & Boekhoudkundige, belasting-en bankemployées & 5.000 & 24 \\
\hline 621 & Lagere commerciële beroepen & 3.000 & $14^{\prime \prime}$ \\
\hline 381-389 & VBO verzorgend & & \\
\hline 621 & Lagere commerciële beroepen & 4.000 & $14^{*}$ \\
\hline 811 & Lagere horecaberoepen & 5.000 & 18 \\
\hline 401 & Bovenbouw HAVO/VWO & & \\
\hline 302 & Middelbare technische, ambachts- en industrieberoepen & 3.000 & $5^{*}$ \\
\hline 6122 & Secretaressen, typisten, & 3.000 & $5^{*}$ \\
\hline 6124 & Boekhoudkundige, belasting- en bankemployées & 8.000 & 14 \\
\hline 6125 & Commercieel-administratieve employées & 7.000 & 13 \\
\hline 6126 & Telefonisten, balie-employées, enquêteurs e.d. & 3.000 & $5^{*}$ \\
\hline 621 & Lagere commerciële beroepen & 3.000 & $5^{*}$ \\
\hline 622 & Middelbare commerciële beroepen & 3.000 & $5^{*}$ \\
\hline $421-429$ & MBO agrarisch & & \\
\hline 2 & Agrarische beroepen & 7.000 & 64 \\
\hline
\end{tabular}




$436-439$
302
331
341
361
362
372
391
6125
622

$453,461-464$
302
603
6121
6122
6124
6125
6126
6131
621
622

451,454

5021

5022

$481,484,486$

811

8212

822

491-494

912

922

\section{5,6 verzorgend 0 \\ 1 \\ 302 \\ 5021 \\ 5023-5025}

503

603

6124

6125

702

703

$\mathbf{5 , 6}$ technisch
0
302
303
6131

MBO technisch

Middelbare technische, ambachts- en industrieberoepen $\quad 15.000$

Lagere hout-en papierberoepen

3.000

4.000

Lagere grafische beroepen

12.000

3.000

Middelbare metaalberoepen

Middelbare elektrotechnische beroepen

9.000

3.000

3.000

Commercieel-administratieve employées

Middelbare commerciële beroepen

3.000

MBO economisch-administratief

Middelbare technische, ambachts- en industrieberoepen

5.000

3.000

3.000

Leidinggevend administratief personeel

Secretaressen, typisten

Boekhoudkundige, belasting- en bankemployées

Commercieel-administratieve employées

Telefonisten, balie-employées, enquêteurs e.d.

Systeemanalisten, -programmeurs en -beheerders

Lagere commerciële beroepen

Middelbare commerciële beroepen

10.000

21.000

15.000

4.000

4.000

7.000

14.000

18
4
$5^{*}$
14
4
11
$4^{*}$
$4^{*}$
$4^{*}$

MBO verpleging en ziekenverzorging

Gediplomeerde verpleegkundigen, verloskundigen $\quad 13.000$

7.000

45

24

MBO verzorgend

Lagere horecaberoepen

Kinder-, gezins-, bejaardenverzorgenden

Middelbare verzorgende beroepen

3.000

5.000

3.000

$11^{*}$

19

$11^{*}$

MBO politie en defensie

Middelbare politie-, brandweer- en bewakingsberoepen $\quad 7.000$

47

Middelbare militaire beroepen

3.000

$20 *$

Hoger onderwijs verzorgend

Pedagogische beroepen

33.000

8.000

Culturele beroepen

4.000

7.000

5

$3^{*}$

9

19

14

$4^{*}$

6

13

Middelbare technische, ambachts- en industrieberoepen

Gediplomeerde verpleegkundigen verloskundigen

Dokters-, tandarts-, apothekersassistenten

en andere paramedici

3.000

16.000

3.000

Hogere economisch-administratieve beroepen

Boekhoudkundige, belasting- en bankemployées

3.000

3.000

3.000

Middelbare sociaal-culturele beroepen

16.000

28

7

3*

6

$3^{*}$

13

$3^{*}$

3 *

$3^{*}$

$3^{*}$

Hogere sociaal-culturele beroepen

13

\section{Hoger onderwijs technisch}

Pedagogische beroepen

3.000

$8^{*}$

Middelbare technische, ambachts- en industrieberoepen

Hogere technische, ambachts- en industrieberoepen

8.000

22

Systeemanalisten, -programmeurs en -beheerders

4.000

4.000

$11^{*}$

$11^{*}$ 
$-85-$

5,6 economisch Hoger onderwijs economisch

302

Middelbare technische, ambachts- en industrieberoepen

4.000

$8^{*}$

Hogere economisch-administratieve beroepen

3.000

$6^{*}$

Secretaressen, typisten

5.000

10

6122

Boekhoudkundige, belasting- en bankemployées

6.000

13

6125

Commercieel-administratieve employées

3.000

$6^{*}$

Systeemanalisten, -programmeurs en -beheerders

4.000

Economen, accountants e.a. economische specialisten

4.000

$8^{*}$

6132

Hogere bestuurlijke en juridische beroepen

6.000

13

* = grote marges

Bron: CBS 
Tabel B.4. In- en uitgaande pendel naar beroepssector per opleidingscategorie, gemiddelde 1990-1991

\begin{tabular}{|c|c|c|c|}
\hline & & aantal & $\%$ \\
\hline $\begin{array}{l}0,1,2 \\
\text { Inkomende pendel }\end{array}$ & Basisonderwijs & & \\
\hline 4 & Transportberoepen & 4.000 & $25^{*}$ \\
\hline 8,9 & $\begin{array}{l}\text { Verzorgende en dienstverlenende beroepen en } \\
\text { openbare orde- en veiligheidsberoepen }\end{array}$ & 3.000 & $19^{*}$ \\
\hline $\begin{array}{l}\text { Uitgaande pendel } \\
4\end{array}$ & Transportberoepen & 3.000 & $27^{*}$ \\
\hline $\begin{array}{l}301 \\
\text { Inkomende pendel }\end{array}$ & MAVO en onderbouw HAVONWO & & \\
\hline $\begin{array}{l}611-612 \\
\text { Uitgaande pendel }\end{array}$ & Lagere en middelbare administratieve beroepen & 6.000 & 46 \\
\hline $611-612$ & Lagere en middelbare administratieve beroepen & 4.000 & $40^{*}$ \\
\hline Rest 3 & VBO & & \\
\hline Inkomende pendel & Aararische, voedinas- en aenotmiddelen- textiel- & & \\
\hline & hout- en papier-, grafische, chemische beroepen & 3.000 & $12^{*}$ \\
\hline $36-39$ & $\begin{array}{l}\text { Metaal-, elektrotechnische, bouwmaterialen-, glas- en } \\
\text { aardewerkberoepen }\end{array}$ & 5.000 & 19 \\
\hline 4 & Transportberoepen & 3.000 & $12^{*}$ \\
\hline $611-612$ & Lagere en middelbare administratieve beroepen & 5.000 & 19 \\
\hline 8,9 & $\begin{array}{l}\text { Verzorgende en dienstverlenende beroepen en } \\
\text { openbare orde- en veiligheidsberoepen }\end{array}$ & 3.000 & $12^{*}$ \\
\hline $\begin{array}{l}\text { Uitgaande pendel } \\
36-39\end{array}$ & $\begin{array}{l}\text { Metaal-, elektrotechnische, bouwmaterialen-, glas- en } \\
\text { aardewerkberoepen }\end{array}$ & 3.000 & $17^{*}$ \\
\hline 4 & Transportberoepen & 3.000 & $17^{*}$ \\
\hline $611-612$ & Lagere en middelbare administratieve beroepen & 4.000 & $22^{*}$ \\
\hline $\begin{array}{l}401 \\
\text { Inkomende pendel }\end{array}$ & Bovenbouw HAVO/VWO & & \\
\hline $\begin{array}{l}611-612 \\
\text { Uitgaande pendel }\end{array}$ & Lagere en middelbare administratieve beroepen & 7.000 & 39 \\
\hline $611-612$ & Lagere en middelbare administratieve beroepen & 5.000 & 39 \\
\hline $\begin{array}{l}\text { 42-44,452 } \\
\text { Inkomende pendel }\end{array}$ & MBO agrarisch, technisch, vervoer en laboratorium & & \\
\hline 30 & Technische, ambachts- en industrieberoepen & 6.000 & 21 \\
\hline $2,31-35$ & $\begin{array}{l}\text { Agrarische, voedings- en genotmiddelen-, textiel-, } \\
\text { hout- en papier-, grafische, chemische beroepen }\end{array}$ & 3.000 & $10^{*}$ \\
\hline $36-39$ & $\begin{array}{l}\text { Metaal, elektrotechnische, bouwmaterialen-, glas- en } \\
\text { aardewerkberoepen }\end{array}$ & 10.000 & 35 \\
\hline Uitgaande pendel & & & \\
\hline $\begin{array}{l}30 \\
2,31-35\end{array}$ & $\begin{array}{l}\text { Technische, ambachts- en industrieberoepen } \\
\text { Agrarische, voedings- en genotmiddelen-, textiel-, } \\
\text { hout- en papier-, grafische, chemische beroepen }\end{array}$ & $\begin{array}{l}4.000 \\
3.000\end{array}$ & $\begin{array}{l}19^{*} \\
14^{*}\end{array}$ \\
\hline $36-39$ & $\begin{array}{l}\text { Metaal, elektrotechnische, bouwmaterialen-, glas- en } \\
\text { aardewerkberoepen }\end{array}$ & 7.000 & 33 \\
\hline
\end{tabular}




\begin{tabular}{|c|c|c|c|}
\hline $453,461-464$ & MBO economisch-administratief & & \\
\hline $611-612$ & Lagere en middelbare administratieve beroepen & 16.000 & 49 \\
\hline 62 & Commerciële beroepen & 6.000 & 18 \\
\hline $60,613,63$ & Hogere economisch-administratieve beroepen & 4.000 & $12^{*}$ \\
\hline Uitgaande pendel & & & \\
\hline $611-612$ & Lagere en middelbare administratieve beroepen & 9.000 & 41 \\
\hline 62 & Commerciële beroepen & 5.000 & 23 \\
\hline $60,613,63$ & Hogere economisch-administratieve beroepen & 3.000 & $14^{*}$ \\
\hline $\begin{array}{l}\text { Rest } 4 \\
\text { Inkomende pendel }\end{array}$ & MBO overig & & \\
\hline 5 & Medische en paramedische beroepen & 6.000 & 30 \\
\hline $611-612$ & Lagere en middelbare administratieve beroepen & 3.000 & $15^{*}$ \\
\hline 8,9 & $\begin{array}{l}\text { Verzorgende en dienstverlenende beroepen en } \\
\text { openbare orde- en veiligheidsberoepen }\end{array}$ & 6.000 & 30 \\
\hline Uitgaande pendel & & & \\
\hline 5 & Medische en paramedische beroepen & 5.000 & 36 \\
\hline 8,9 & $\begin{array}{l}\text { Verzorgende en dienstverlenende beroepen en } \\
\text { openbare orde- en veiligheidsberoepen }\end{array}$ & 4.000 & $29^{*}$ \\
\hline $\begin{array}{l}\text { 5-6 } \\
\text { Inkomende pendel }\end{array}$ & Hoger onderwijs & & \\
\hline $0,1,7$ & Pedagogische, culturele en sociaal-culturele beroepen & 18.000 & 26 \\
\hline 30 & Technische, ambachts- en industrieberoepen & 9.000 & 13 \\
\hline $36-39$ & $\begin{array}{l}\text { Metaal, elektrotechnische, bouwmaterialen-, glas- en } \\
\text { aardewerkberoepen }\end{array}$ & 4.000 & $6^{*}$ \\
\hline 5 & Medische en paramedische beroepen & 8.000 & 12 \\
\hline $611-612$ & Lagere en middelbare administratieve beroepen & 10.000 & 15 \\
\hline $60,613,63$ & Hogere economisch-administratieve beroepen & 12.000 & 17 \\
\hline 8,9 & $\begin{array}{l}\text { Verzorgende en dienstverlenende beroepen en } \\
\text { openbare orde- en veiligheidsberoepen }\end{array}$ & 3.000 & $4^{*}$ \\
\hline Uitgaande pendel & & & \\
\hline $0,1,7$ & Pedagogische, culturele en sociaal-culturele beroepen & 18.000 & 30 \\
\hline 30 & Technische, ambachts- en industrieberoepen & 7.000 & 12 \\
\hline $36-39$ & $\begin{array}{l}\text { Metaal, elektrotechnische, bouwmaterialen-, glas- en } \\
\text { aardewerkberoepen }\end{array}$ & 3.000 & $5^{*}$ \\
\hline 5 & Medische en paramedische beroepen & 8.000 & 13 \\
\hline $611-612$ & Lagere en middelbare administratieve beroepen & 7.000 & 12 \\
\hline $60,613,63$ & Hogere economisch-administratieve beroepen & 12.000 & 20 \\
\hline
\end{tabular}

* = grote marges 
Tabel B.5. Percentage baanvinders naar beroepssector per opleidingscategorie, gemiddelde 1990-1991

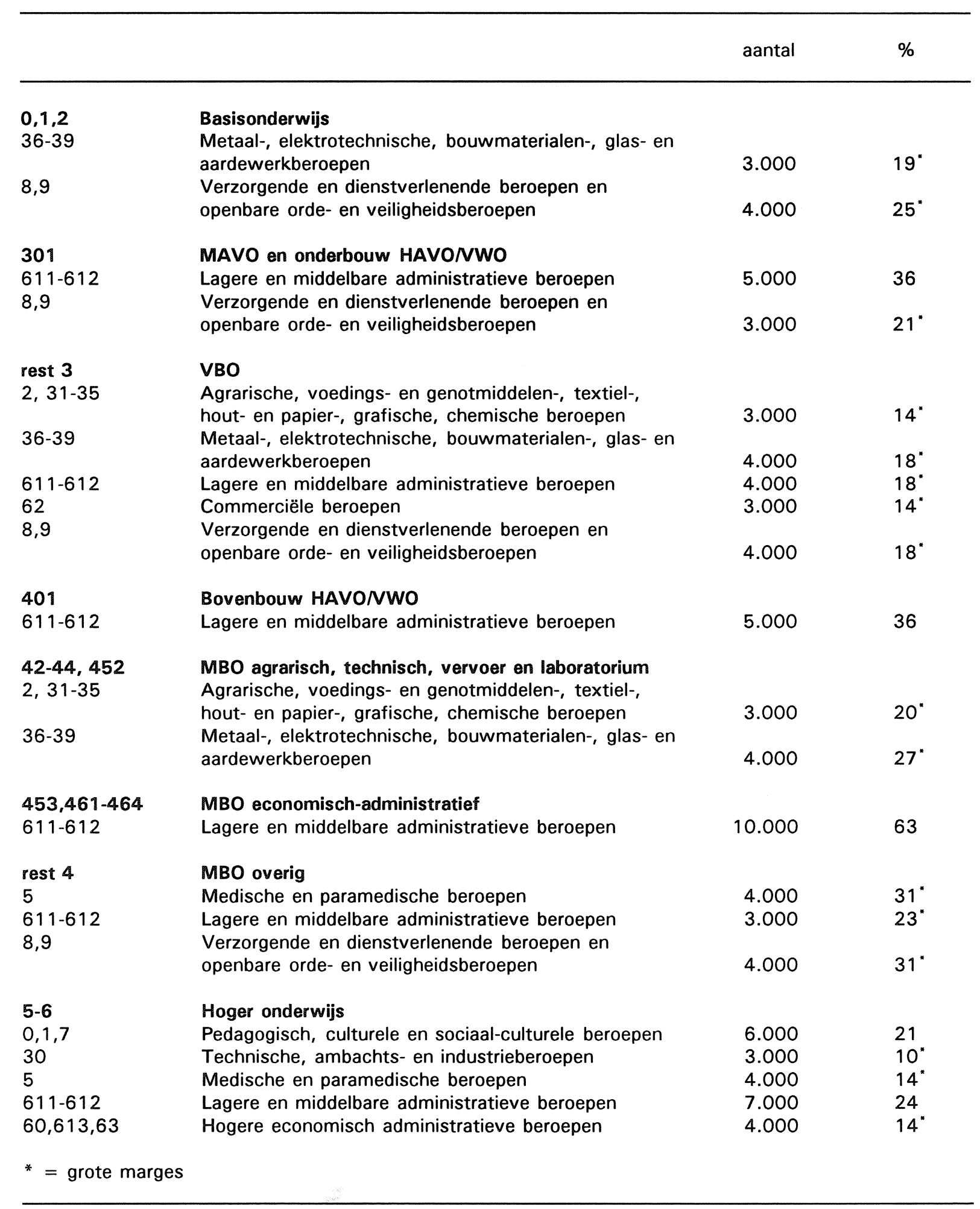

Bron: CBS 